\title{
DEREGULATION, ENTRY OF FOREIGN BANKS AND BANK EFFICIENCY IN AUSTRALIA
}

\author{
JAN-EGBERT STURM \\ BARRY WILLIAMS
}

CESIFO WORKING PAPER No. 816

CATEGORY 9: INDUSTRIAL ORGANISATION

DECEMBER 2002

An electronic version of the paper may be downloaded

- from the SSRN website: www.SSRN.com

- from the CESifo website: www.CESifo.de 


\title{
DEREGULATION, ENTRY OF FOREIGN BANKS AND BANK EFFICIENCY IN AUSTRALIA
}

\begin{abstract}
This study considers the efficiency of banking in Australia during the postderegulation period 1988-2001. Since 1986 restrictions upon foreign bank entry and foreign ownership have been affectively abolished. Using Data Envelopment Analysis (DEA) and Malmquist Indices, we find that the new foreign banks are more (input) efficient than domestic banks, mainly due to their superior scale efficiency. However, this superior efficiency did not necessarily result in superior profits. Our results are consistent with the limited global advantage hypothesis of Berger et al (2000). We argue that the major Australian banks have used size as a barrier to entry to the new entrants in the post-deregulation period. Furthermore, bank efficiency seems to have increased post-deregulation and the competition resulting from diversity in bank types was important to prompt improvements in efficiency. Finally, the recession of the early 1990s resulted in a distinct shift in the process of efficiency changes.
\end{abstract}

Keywords: foreign banks, deregulation, data envelopment analysis, Malmquist indices.

JEL Classification: G21, G28.

Jan-Egbert Sturm

CESifo (University of Munich \& Ifo

Institute for Economic Research)

Poschingerstraße 5

81679 Munich

Germany

sturm@ifo.de
Barry Williams

School of Business

Bond University

Gold Coast

Queensland 4229

Australia

Barry_Williams@bond.edu.au 


\section{Introduction.*}

This study compares the efficiency of foreign-owned banks operating in Australia with Australian domestic banks after deregulation of the Australian banking system during the early and mid 1980s. The objective is to determine if foreign banks were more efficient than domestic banks during our estimation period of 1988 to 2001. Previous Australian studies have largely ignored foreign-owned banks when studying efficiency of the Australian banking system. To date only Sathye (2001) has compared foreign banks with domestic banks for a single year (1996), and suggested that foreign banks are less efficient than domestic banks in Australia. This study will consider a longer time period to determine if the results of this single study apply to the period immediately following deregulation as well as more recently. Further, Walker (1998) found no evidence of diseconomies of scale in the Australian banking system between 1978 and 1990, using a sample that excluded foreign-owned banks.

This paper will employ Data Envelopment Analysis (DEA) and Malmquist Indices to consider the efficiency of both foreign and domestic banks and the dynamics of efficiency changes in Australia post-deregulation. The Australian banking system is dominated by 4 large banks, as well as having a number of smaller domestic banks, which are mainly regional retail banks. Thus, the domestic banks in this study will be categorised as either Big Four or Other Domestic. This categorisation will aid in consideration of the impact of different operational types upon observed efficiency. Further, the paper will consider several different definitions of inputs and outputs to determine if these differences have any impact upon differences in measured efficiency. This approach will have the benefit of considering the multiproduct nature of bank inputs and outputs.

The DEA results show that foreign banks were, on average, more input efficient than the domestic banks, mainly due to superior scale efficiency, which is opposite to findings of other studies (Berger $e t$ $a l, 2000)$. We argue that these results tend to support the limited form of the global advantage hypothesis as proposed by Berger et al (2000). The major (Big Four) banks used size as a barrier to entry to the new entrants. However, the major banks also displayed superior pure technical efficiency. The superior input efficiency of foreign banks did not necessarily result in higher profits, consistent with Claessens et al (2001), DeYoung and Nolle (1996) and Williams (2002). The Malmquist Index results indicate that bank efficiency increased post-deregulation, and that the diversity in types of banks operating in Australia was an important source of the dynamic in efficiency changes. As a result of this dynamic, the overall differences in efficiency changes between the bank categories have reduced. The recession of the early 1990s resulted in technological regress, as compared to the period immediately following deregulation, which saw high levels of technological innovation, consistent with Claessens et al (2001). We also conclude that the choice of inputs and outputs impacts upon the finding of relative efficiency, consistent with Berger et al (1993).

The authors are grateful for comments from seminar participants at the Australasian Finance and Banking conference, especially Allen Berger, and seminar participants at Bond University, the Graduate School of Business, The University of Melbourne and Australian National University, especially Bruce Grundy and Noel Gaston. All remaining errors are the responsibility of the authors. 
The outline of this paper is as follows. The next section will provide some background to the process of deregulation in Australia. The third section will provide an overview of previous studies that have considered efficiency of the Australian banking system, the efficiency of foreign banks and the efficiency effects of financial system deregulation. The fourth section will discuss the data and methodology employed, while the fifth section will discuss the results. The final section will provide conclusions and directions for further research.

\section{Deregulation in Australia.}

Prior to 1979 Australia had a highly regulated banking system, with the Reserve Bank of Australia determining the price of both deposits and loans. The regulations in Australia restricted banking system flexibility, but the quid pro quo was protection from new entry (Pauly, 1987). The regulatory structure generated high profits for the incumbent banks by international standards (Revell, 1980). The Australian Financial System Inquiry Final Report (1981), (otherwise known as the Campbell Committee), recommended that the financial system should be deregulated.

The Campbell Committee considered the commissioned study by Swan and Harper (1982) to be persuasive. This study emphasised the economy-wide benefits that would result from deregulation increasing the efficiency of the banking system. Symptoms of inefficiencies resulting from the system of regulations in place included internal cross-subsidies and over-provision of branch networks (Swan and Harper, 1982). ${ }^{1}$ For our purpose, the main consequence of deregulation was the access of foreign banks into Australia. ${ }^{2}$

As a defensive reaction to the threat of foreign bank entry, there were mergers among the major six domestic banks during the deregulation period (Stearn and Tress, 1983; Hall, 1987). ${ }^{3}$ The Bank of NSW merged with the Commercial Bank of Australia to form Westpac, and the National Bank of Australasia merged with the Commercial Banking Company of Sydney to establish National Australia Bank (NAB), both in June 1981.

Australia had an established history of restrictions upon foreign bank entry post World War Two. ${ }^{4}$ Further, there were restrictions upon foreign ownership of non-bank financial institutions (NBFIs) (Pauly, 1987). In September 1984 applications were accepted from foreign banks for full banking status and restrictions upon foreign ownership of NBFIs were lifted. In 1985 sixteen foreign banks were granted licences to operate in Australia as subsidiary banks, of these, fifteen eventually established operations. ${ }^{5}$ It was originally anticipated that these sixteen licences would be the entire

1 For further detail on the arguments for deregulation in Australia, see also Perkins (1989) and Harper (1986).

2 Other key aspects of deregulation included (i) the removal of qualitative and quantitative controls upon bank balance sheets, (ii) the floating of the Australian dollar in 1983, and (iii) the use of market-based operations for the implementation of monetary policy.

3 Detailed timelines of financial deregulation in Australia are available in Lewis and Wallace (1997) and Carew (1998).

4 Two foreign banks operated in Australia post World War Two as branches for historical reasons (Pauly, 1987).

5 J.P Morgan did not take up its licence. The announcement of sixteen licences was in excess of industry expectations, which were in the range of six to eight. 
ration of such licences. ${ }^{6}$ All of the foreign banks that elected to take up their licences were operating by May 1986.

A survey by Davis and Lewis (1982) considered that foreign banks have three advantages relative to domestic competitors; (i) significant knowledge capital, (ii) ownership of new technology, and (iii) superior skill in funds allocation. The Reserve Bank of Australia (RBA) considered that foreign bank entry would provide a competitive stimulus to the banking system (Davis and Lewis, 1982, p 539). Foreign banks were also considered to innately possess economies of scale and so were capable of immediately competing with the incumbent banks (RBA, 1994). ${ }^{7}$ Foreign banks have an active preference for operations as branches rather than as subsidiaries (Davis and Lewis, 1982). ${ }^{8}$ In 1992 branch operations were permitted. However, some tax-related issues delayed conversion of subsidiaries to branches until 1994 (East, 1993).

The entrance of foreign banks into Australia has been regarded as a failure. This is particularly due to their inability to reach the target they set themselves of a twenty percent market share within five years of entry (Metcalfe, 1985; Standing Committee of Finance and Public Administration, 1991). Other factors contributing to this perception include the lack of impact the foreign banks have made upon the retail market (Ackland and Harper, 1992), and the poor profits of some of the new entrants (Ferguson, 1990). This poor performance has been attributed to the high entry barriers the foreign banks faced upon entry, (SCOFPA, 1991, p 151), with the foreign banks being considered the cannon fodder of deregulation (Ferguson, 1990, pp 4 - 5). It has been argued that the foreign banks were never likely to succeed, given the creation of four dominant banks by the mergers of 1981, and the increased spending of these four banks to increase these barriers to entry (Ferguson, 1990). The newly licensed banks operating in Australia, ${ }^{9}$ including the foreign banks, have also been regarded as less efficient and productive than the existing banks (Hogan, 1991).

\section{Literature Review.}

There are three streams of literature that are relevant to this study, (i) those dealing with bank efficiency in Australia, (ii) those comparing foreign bank efficiency with domestic bank efficiency and (iii) those considering the impact of deregulation upon bank efficiency.

6 In 1992 this ration was removed and branch operations (subject to restrictions) were permitted.

7 This view regarded the foreign bank's Australian operations as a direct extension of their international operations.

8 A subsidiary is an Australian incorporated bank which has foreign ownership of over $50 \%$ of the equity; the majority of foreign bank subsidiaries in Australia have 100\% foreign ownership. A foreign bank branch is not legally separate from its parent and as such has the full support of the parent's capital base and carries the parent's credit rating. In Australia foreign bank branches are restricted to wholesale banking only. As foreign bank branches are not legally separate from the parent they do not report many of the variables necessary for this study.

9 During the process of deregulation a number of non-bank financial institutions (NBFIs) converted to bank status, these were mainly building societies with a regional focus upon retail finance. One foreign-owned merchant bank (Hill Samuel Australia) listed on the Australian Stock Exchange as Macquarie Bank and became largely Australian-owned with a wholesale focus. 


\section{Australian Studies.}

The Australian banking system has been subject to considerable changes, which brought with them expectations of improved efficiency; however, the literature to date has been relatively sparse. The Financial System Inquiry [FSI] $(1997)^{10}$ considered the impact of deregulation. The FSI considered that there were three types of efficiency gains due to deregulation. These efficiency gains were (i) allocative efficiency, (the allocation of resources to their highest value use); (ii) technical efficiency, (the maximisation of finance sector outputs given its inputs) and (iii) dynamic efficiency, (the extent of product innovation and the application of cost-minimising technology). Worthington (1999) provided some criticisms of the measures used by the FSI to assess these efficiency gains. In particular, the FSI used simple ratios and anecdotal evidence to conclude efficiency gains. This approach considers finance firms as single-product rather than multi-product firms and does not fully capture the dynamics of efficiency changes, unlike the method employed in this paper.

A survey by Berger and Humphrey (1997) did not identify one study of Australian bank efficiency. ${ }^{11}$ More recently, Walker (1998) applied a translog cost function to twelve Australian banks during the period 1978-1990. This study did not include any foreign banks in its sample and concluded that there was no evidence of diseconomies of scale and some evidence of constant returns to scale. Avkiran (1999) considered the efficiency effects of Australian bank mergers. This study considered 23 banks (no foreign banks ${ }^{12}$ ) between 1986 and 1995. It was concluded that bank efficiency increased until 1991 and then declined due to problems associated with bad debts. Avkiran (1999) concluded that acquiring banks are more efficient than target banks pre-merger, but that post-merger efficiency changes could not be conclusively discerned. Avkiran (2000) studied ten domestic Australian banks between 1986 and 1995, to determine the post-deregulation degree of changes in bank productivity. It was concluded that total productivity increased over the study period, but this increase was mainly due to technological progress rather than technical efficiency. Sathye (2002) applied Malmquist indices to 17 Australian banks (1995 to 1999) and concluded that there had been a decline in efficiency over the study period, but did not consider foreign banks. ${ }^{13}$

Allen and Rai (1996) conducted a cross-border study of bank efficiency between 1988 and 1992 and concluded that Australia had a relatively efficient banking system. Worthington (1999) applied Malmquist indices to credit unions in Australia post-deregulation and concluded that there had been technological regress resulting in a $2.14 \%$ decline in total factor productivity over the study period. However, as credit unions are subject to operating conditions different to those faced by licensed banks, this does not necessarily indicate deregulation has resulted in a reduction in Australian financial system efficiency. To date, one Australian study has considered the efficiency of foreign as well as

10 Commonly known as the Wallis Report.

11 A descriptive study was conducted by Oster and Antioch (1995), but this compared generic ratios of bank efficiency and did not conduct any frontier estimation.

12 Avkiran (1999 and 2000) included a foreign-owned bank in both studies (The Bank of Scotland acquired 51\% ownership of BankWest in 1995). Avkiran (1999) included a second foreign bank (National Mutual Royal Bank, a joint venture bank). The foreign ownership issue was not considered in either study.

13 It should be noted that the discussion in Sathye (2002) on page 53 are somewhat inconsistent with the results presented in table 3 on page 54. 
domestic banks, Sathye (2001). Sathye (2001) studied 29 banks in 1996 (12 foreign, 17 domestic) and concluded that Australian banks are, on average, less efficient than world mean bank efficiency. Sathye (2001) also provided some evidence that foreign banks are less efficient than domestic banks, but did not consider the issue of economies of scale.

International Studies of Foreign bank efficiency.

The empirical evidence to date, as surveyed by Berger et al (2000), has found foreign-owned financial institutions to be less efficient than domestic institutions. ${ }^{14}$ In the case of the United States, studies by Hasan and Hunter (1996), Mahajan, Rangan and Zardkoohi (1996), and Chang, Hasan and Hunter (1998) found foreign banks to be less cost efficient than domestic banks, while DeYoung and Nolle (1996) found foreign banks to have lower profit efficiency. A wider ranging study by Miller and Parkhe (2002) considered profit efficiency in fourteen different nations, and found domestic banks to be more efficient than foreign banks. Berger et al (2000) proposed two alternative hypotheses to explain these results. According to the home field advantage, the domestic institutions' efficiency advantage is sourced in costs borne by the foreign institution. These costs include monitoring from a distance and staff turnover in overseas postings. Other problems faced by the foreign banks include diseconomies of operation in the retail sector, barriers to entry such as language, culture, market structure and regulations. ${ }^{15}$ The global advantage hypothesis has two forms: the general form and the limited form. Under the general form, efficient foreign banks from a range of nations are able to offer superior efficiency compared to domestic banks, which has been rejected by the literature to date. Under the limited form of the global advantage hypothesis foreign banks from a particular set of nations are able to offer efficiency superior to the domestic banks. The limited global advantage hypothesis proposes that some efficient foreign banks are able to master the disadvantages presented by the liability of foreignness and operate at superior levels of efficiency compared to their domestic competition. This global advantage may be sourced in management skills, fund raising opportunities or the ownership of best-practice procedures. Berger et al (2000) argued that this nation-specific advantage could be sourced from factors such as home market structure and regulation. The local versus global advantage hypothesis was tested, and the limited global advantage hypothesis was supported. Berger et al (2000) considered both profit and cost efficiency and concluded that while on average domestic banks have higher cost and profit efficiency; disaggregation by nationality found that for three of the five nations studied, foreign banks from the United States were on average more efficient than domestic banks. It was argued that these results were due to actual advantages rather than transfer pricing (Berger et al, 2000, pp $59-60$ ).

\section{International Studies of the Efficiency Effects of Deregulation.}

An important aspect of deregulation is its impact upon the efficiency of the financial system, as a key objective of deregulation is to improve efficiency (Berger and Humphrey, 1997). In the case of the United States it has been generally found that deregulation has been followed by a decline in cost

14 See also Berger, Demsetz and Strahan (1999).

15 These costs are frequently labelled the liability of foreignness, see for example Zaheer (1995), Zaheer and Mosakowski (1997), Miller and Parkhe (2002). 
productivity, with this decline being attributed to depositors gaining from deregulation via higher deposit interest rates (Berger et al, 2000). A recent study by Mukherjee et al (2001) found that productivity declined immediately post-deregulation in the United States. Deregulation of the financial system has occurred in a number of nations. Studies of the impact of deregulation upon efficiency have found mixed results. Improvements in efficiency have been reported for Taiwan (Shyu, 1998), Korea (Gilbert and Wilson, 1998), Norway (Berg et al, 1992), Turkey (Zaim, 1995) and Thailand (Leightner and Lovell, 1998). In the case of Spain (Grifell-Tatje and Lovell, 1996) deregulation was found to have a negative impact upon efficiency.

Studies of the effects of deregulation upon different bank types within a nation have found that deregulation has different effects upon different bank types. In the Indian case, Bhattacharyya et al (1997) found that foreign banks experienced the greatest improvements in efficiency, while private banks had a smaller increase in efficiency and public bank efficiency declined. In the Greek case, Noulas (1997) found that technical efficiency increased for private banks but not for state banks, while there was technological progress for state banks but not for private banks. Berg et al (1992) found that Norwegian banks created idle capacity (excess inputs) pre-deregulation and that post-deregulation improvements in efficiency were mainly the result of the Norwegian banks catching up to efficient output levels. ${ }^{16}$ Overall, the impact of deregulation seems to be determined by the nature of deregulation adopted and the structure of the financial system prior to deregulation.

\section{Method and Data.}

There are a number of alternative methods available to measure bank efficiency, with Berger et al (1993), Berger and Humphrey (1997) and Berger and Mester (1997) providing key surveys of the alternative methods. ${ }^{17}$ This study will employ Data Envelopment Analysis (DEA) and Malmquist Indices. DEA is a non-parametric linear programming method, which does not require input or output prices in order for a best practice production frontier to be identified. The best practice frontier is identified as a piece-wise linear composite of observed best practices, given the specification of inputs and outputs. ${ }^{18}$ The outcome is to produce a convex production frontier for output oriented DEA, while input oriented DEA produces a concave production frontier (Berger and Humphrey, 1997). ${ }^{19}$ DEA generates a within-sample efficiency score between 0 and 1 , with 1 being most efficient. Under the alternative assumptions of Constant Returns to Scale (CRS) and Variable Returns to Scale (VRS) it is possible to decompose the (Technical Efficiency) score into the components of Pure Technical Efficiency and Scale Efficiency. ${ }^{20}$ It is also possible to determine if the individual bank is experiencing

16 This situation has some parallels to the Australian situation discussed in Section 2, where the major Australian banks merged amongst themselves and increased spending, (especially upon branch infrastructure), in order to increase the barriers to entry for the foreign banks (Ferguson, 1990).

17 A valuable reference is also Coelli et al (1998).

18 See, for example, Coelli et al (1998) Chapter 6.

19 Berger and Humphrey (1997) identified over 60 studies that have applied DEA to the banking industry.

20 Technical Efficiency $=$ Scale Efficiency $\times$ Pure Technical Efficiency. 
Increasing, Constant or Decreasing Returns to Scale. ${ }^{21}$ A separate production frontier will be estimated for each year of this study.

The Malmquist Index approach is a chained index approach, which measures changes in efficiency relative to a base year. ${ }^{22}$ Production frontiers for a base year and successive years are estimated and each firm's movements in efficiency relative to these frontiers are estimated. The Malmquist Index approach measures efficiency changes with respect to a base year value of 1 . If the index for the year, other than the base year, is above 1, there has been an efficiency improvement. On the other hand, if the index value for the year is below 1 there has been efficiency regress. These changes in efficiency can be decomposed into components due to changes in technical efficiency (catching up) and movements due to changes in technology (technological change). Changes in a firm's technical efficiency can be decomposed into change due to pure technical efficiency change and changes due to scale efficiency. ${ }^{23}$

This study will consider banks operating in Australia between 1988 and 2001. While foreign banks commenced operations in 1986, their annual reports for 1987 in many cases reflected results for a portion of the year. Thus comparing the foreign bank results with those for domestic banks, which reported for the entire financial year, would be inappropriate. The primary data source for this study is the banks annual reports. These were individually obtained from each bank. ${ }^{24}$ Details regarding housing loans were obtained from the Reserve Bank of Australia Bulletin and the earlier Australian Government Gazette. Sufficient data was available for thirty-six banks to be included in the sample. The banks are categorised as Big Four, Other Domestic and Foreign. The Big Four banks are the dominant banks in the Australian banking industry, with 67.8\% of total bank assets in 1988 and $65.7 \%$ of total bank assets in $1998 .^{25}$ The Other Domestic banks consist primarily of regional banks with a retail focus, with the exception of Macquarie Bank, which focuses upon wholesale banking. The Other Domestic banks were mainly state-owned banks in the early years of the sample, with converted building societies increasing in importance in the later years of the sample period. There are a total of 14 Other Domestic banks in this study. The foreign banks are all those banks with more than $50 \%$ foreign ownership, the majority of the foreign banks are wholly-owned subsidiaries of foreign banks. ${ }^{26}$ Due to their status as wholly-owned subsidiaries, the annual reports produced by the foreign banks, in many cases, had a lower level of disclosure. ${ }^{27}$ There are a total of 18 foreign banks in this study. ${ }^{28}$

21 Interested readers are referred to Coelli et al (1998), Chapters 6 and 7 for further details.

22 Relevant studies include Berg et al (1992) and Färe et al (1994).

23 Effch: technical efficiency change. Techch: technological change. Pech: pure technical efficiency change. Sech: scale efficiency change. Tfpch: total factor productivity change. Effch $=$ Pech $*$ Sech. Tfpch $=$ Effch $*$ Techch.

24 Annual reports were not available from foreign bank branches and so they are excluded from this study.

25 Reserve Bank of Australia Bulletin, various issues.

26 Of the foreign banks in this study, BankWest, Bank of America, Bank of Singapore, Chase AMP, National Mutual Royal operated as joint venture banks with majority foreign ownership. With the exception of BankWest, these joint ventures were relatively short lived, with the banks either exiting (National Mutual Royal) or converting to 100\% foreign ownership.

27 These banks are not listed on the stock exchange and so are subject to less onerous disclosure requirements.

28 This is more than the 15 foreign banks mentioned in the second section. As a bank was restructured it was counted as a new bank. This applied in three cases; (i) Chase AMP dissolved its joint venture and re-established Australian operations as Chase Manhattan; (ii) Bank of Tokyo and Mitsubishi Bank merged their operations at home, and as a result Bank of 
Restrictions resulting from data availability dictated the research method chosen. Mergers, changes of ownership and data availability meant that some banks were not included in every year of the sample period. ${ }^{29}$ The impact of mergers amongst the banks as well as conversion by foreign banks to branch status resulted in a decline in the sample size for each year across the sample period.

In order to employ DEA and Malmquist Indices inputs and outputs must be specified. This study will employ the intermediation approach in which banks are viewed as financial intermediaries employing inputs such as labour, capital and deposits to produce outputs such as loans and off-balance sheet items. ${ }^{30}$ Four alternative specifications of inputs and outputs are employed in this study. The most parsimonious model (Model 1) has inputs as (i) employee numbers, (ii) deposits and borrowed funds and (iii) equity capital. Outputs are (i) loans advances and other receivables and (ii) off-balance sheet activity measured as commitments and contingent liabilities. ${ }^{31}$ Model 1a decomposes outputs in Model 1 by dividing loans into two categories, (i) loans advances and other receivables less housing loans, and (ii) housing loans. This approach has the advantage of acknowledging that some banks have a greater focus upon retail activity (with a different cost structure), but brings with it a disadvantage that housing loans are not available for all banks for the entire study period. ${ }^{32}$ Model $1 \mathrm{~b}$ is identical to Model 1, but includes investments (liquid assets, trading securities, bill acceptances and other investments) as an additional output. Model $1 \mathrm{~b}$ acknowledges the impact of an increased wholesale activity. Model 2 provides a mechanism to compare the results of this study with the previous studies by Avkiran (1999 and 2000), that excluded foreign banks. In Model 2, inputs are (i) interest expenses, and (ii) non-interest expenses, while outputs are (i) net interest income and, (ii) non-interest income. These measures of inputs and outputs are revenue focussed, and as efficiency estimates are sensitive to specification of inputs and outputs, (Berger et al, 1993), it is expected that this revenue focussed model will yield some differences.

Table 1 details the characteristics of the sample used in Model 1 for DEA estimation, which had the largest sample size. ${ }^{33}$ The sample composition for the Malmquist Index estimation is detailed in Table 2. Given the available data, the maximum sample size for each Malmquist Index Model was selected, resulting in different sample sizes, with Models 1 and $1 \mathrm{~b}$ having the largest sample, 15 banks over six years; and Model 2 having the smallest sample, 13 banks over six years. It is worth noting that the Malmquist Index approach is a chained index approach and as such the first year is used as a reference

Tokyo/Mitsubishi Australia was formed; (iii) the regional domestic R\&I Bank was sold to Bank of Scotland and restructured as BankWest. In each of these cases the restructured bank was treated as a new bank.

29 In each case of a re-structure the new entity was treated as a new bank, as discussed above. As a separate production frontier was estimated for each year, this process does not create any bias.

30 There is some controversy regarding the specification of inputs and outputs in banking, see for example Berger and Humphrey (1992). Favero and Papi (1995) found that their results were not sensitive to respecifying deposits as an output rather than as an input.

31 This definition of off-balance sheet activity excludes market-related activity such as derivatives due to lack of data availability for the entire sample period. Off balance sheet items are measured as face value, as risk weighted values were not reported for the entire sample period.

32 This problem particularly relates to the early part of the study period when housing loans were reported in the Australian Government Gazette. In the case of trading banks (pre 1989) housing loans were not reported. In most cases foreign banks operated in Australia as a trading bank, the distinction between trading banks and savings banks was removed during the deregulation process.

33 Sample details relating to Models 1a, $1 \mathrm{~b}$ and 2 are in the Appendix of this paper as Tables A1 to A3 respectively. 
year. Thus the results for the Malmquist Index analysis will exclude results for the first year of each sample.

Table 1.

Sample Characteristics of Model 1: DEA.

\begin{tabular}{|c|c|c|c|c|}
\hline Year & Big4 & $\begin{array}{c}\text { Other } \\
\text { Domestic }\end{array}$ & Foreign & Total \\
\hline 1988 & 2 & 3 & 13 & 18 \\
1989 & 3 & 8 & 15 & 26 \\
1990 & 3 & 7 & 13 & 23 \\
1991 & 4 & 9 & 13 & 26 \\
1992 & 4 & 9 & 12 & 25 \\
1993 & 4 & 9 & 11 & 24 \\
1994 & 4 & 10 & 11 & 25 \\
1995 & 4 & 10 & 9 & 23 \\
1996 & 4 & 10 & 6 & 20 \\
1997 & 4 & 7 & 6 & 17 \\
1998 & 4 & 5 & 4 & 13 \\
1999 & 4 & 5 & 4 & 13 \\
2000 & 4 & 4 & 2 & 10 \\
2001 & 4 & 5 & 1 & 10 \\
\hline
\end{tabular}

Model 1: Inputs; (i) employees, (ii) deposits, (iii) equity capital. Outputs: (i) loans, (ii) off-balance sheet items.

Table 2.

Malmquist Index Sample Characteristics.

\begin{tabular}{|l|c|c|c|c|c|c|}
\hline \multicolumn{1}{|c|}{ Model } & Big 4 & $\begin{array}{c}\text { Other } \\
\text { Domestic }\end{array}$ & Foreign & $\begin{array}{c}\text { Total } \\
\text { Banks }\end{array}$ & Years & $\begin{array}{c}\text { Total } \\
\text { Observations }\end{array}$ \\
\hline Model 1 & 3 & 5 & 7 & 15 & 1989 to 1995 & 105 \\
Model 1a & 3 & 6 & 7 & 16 & 1990 to 1995 & 96 \\
Model 1b & 3 & 5 & 7 & 15 & 1989 to 1995 & 105 \\
Model 2 & 4 & 6 & 3 & 13 & 1989 to 1995 & 91 \\
\hline
\end{tabular}

Model 1: Inputs: (i) employees, (ii) deposits, (iii) equity capital. Outputs: (i) loans, (ii) off balance sheet items.

Model 1a: Inputs: (i) employees, (ii) deposits, (iii) equity capital. Outputs: (i) loans less housing loans, (ii) housing loans (iii) off balance sheet items.

Model 1b Inputs: (i) employees, (ii) deposits, (iii) equity capital. Outputs: (i) loans, (ii) investments, (iii) off balance sheet items.

Model 2: Inputs: (i) interest expenses, (ii) non-interest expenses. Outputs: (i) net interest income, (ii) noninterest income.

The maximum sample size was selected for each model. 
Table 3 shows the descriptive statistics for the sample used. All values except employee numbers are in thousands of Australian dollars. Panel A of Table 3 shows the overall descriptive statistics, while Panels B, C and D, show respectively the segmented descriptive statistics for the Big Four, Other Domestic and Foreign banks. The Other Domestic banks tend to have higher levels of housing loans, while the Foreign banks tend to have higher levels of off-balance sheet activity and non-interest income, while unsurprisingly, the Big Four banks are the largest.

Table 3.

Descriptive Statistics: Entire Sample: 1988 to 2001

\$A 000s, except employees.

\section{Panel A: All Banks}

\begin{tabular}{|l|c|c|c|c|c|}
\hline \multicolumn{1}{|c|}{ Variable } & Observations & Mean & Std Deviation & Minimum & Maximum \\
\hline Deposits & 274 & $17,126,535.08$ & $31,253,061.67$ & $95,779.00$ & $185,097,000.00$ \\
Employees & 255 & $8,528.18$ & $15,013.89$ & 45.00 & $50,367.00$ \\
Equity capital & 274 & $1,871,828.74$ & $3,440,163.65$ & $25,234.00$ & $21,407,000.00$ \\
Housing loans & 261 & $4,610,771.29$ & $7,795,707.82$ & 0 & $34,155,000.00$ \\
Interest expense & 273 & $1,316,116.87$ & $2,228,427.77$ & $6,151.00$ & $11,146,000.00$ \\
Investments & 274 & $3,655,175.87$ & $5,944,115.20$ & $2,701.00$ & $32,614,000.00$ \\
Loans & 274 & $17,576,890.57$ & $32,399,683.17$ & $300,490.00$ & $195,492,000.00$ \\
Non interest income & 264 & $497,183.29$ & $923,551.05$ & $1,686.00$ & $6,523,000.00$ \\
Non interest expense & 238 & $876,810.12$ & $1,407,196.58$ & $8,431.00$ & $7,229,000.00$ \\
Net interest income & 273 & $724,001.63$ & $1,329,037.16$ & -856.00 & $6,371,000.00$ \\
Off balance sheet & 262 & $774,202.81$ & $16,401,153.85$ & 0.00 & $93,611,000.00$ \\
activity & & & & \\
\hline
\end{tabular}

Panel B: Big Four Banks

\begin{tabular}{|l|c|c|c|c|c|}
\hline \multicolumn{1}{|c|}{ Variable } & Observations & Mean & Std Deviation & Minimum & Maximum \\
\hline Deposits & 48 & $77,896,052.08$ & $30,563,418.44$ & $33,036,300.00$ & $185,097,000.00$ \\
Employees & 48 & $38,943.06$ & $6,318.81$ & $23,134.00$ & $50,367.00$ \\
Equity capital & 48 & $8,428,083.33$ & $3,658,608.87$ & $3,766,100.00$ & $21,407,000.00$ \\
Housing loans & 48 & $18,262,241.25$ & 8340088.53 & 5053000.00 & 34155000.00 \\
Interest expense & 48 & $5,758,618.75$ & 1847994.75 & 3103400.00 & 11146000.00 \\
Investments & 48 & $14,452,445.83$ & $5,253,018.62$ & $7,705,100.00$ & $32,614,000.00$ \\
Loans & 48 & $79,860,500.00$ & $33,476,104.11$ & $35,339,800.00$ & $195,492,000.00$ \\
Non interest income & 48 & $2,056,968.75$ & $950,570.09$ & $813,000.00$ & $6,523,000.00$ \\
Non interest expense & 48 & $3,416,660.42$ & $933,116.91$ & $2,061,200.00$ & $7,229,000.00$ \\
Net interest income & 48 & $3,435,612.50$ & $954,508.62$ & $2,072,100.00$ & $6,371,000.00$ \\
Off balance sheet & 46 & $39,364,732.61$ & $17,623,005.26$ & $5,510,000.00$ & $93,611.000 .00$ \\
activity & & & & \\
\hline
\end{tabular}


Panel C: Other Domestic Banks.

\begin{tabular}{|l|c|c|c|c|c|}
\hline \multicolumn{1}{|c|}{ Variable } & Observations & Mean & Std Deviation & Minimum & Maximum \\
\hline Deposits & 115 & $6,727,316.49$ & $7,232,348.04$ & $540,753.00$ & $37,853,919.00$ \\
Employees & 100 & $2,360.45$ & $2,137.28$ & 530.00 & $11,253.00$ \\
Equity capital & 115 & $667,640.06$ & $835,025.08$ & $62,388.00$ & $3,859,000.00$ \\
Housing loans & 105 & $2,682,914.35$ & $3,322,930.44$ & $7,000.00$ & $18,199,000.00$ \\
Interest expense & 115 & $515,467.42$ & $525,111.54$ & $6,151.00$ & $2,145,500.00$ \\
Investments & 115 & $1,888,121.76$ & $3,492,263.96$ & $54,485.00$ & $29,247,000.00$ \\
Loans & 115 & $6,516,643.14$ & $7,479,304.29$ & $485,509.00$ & $39,454,000.00$ \\
Non interest income & 115 & $221,516.38$ & $565,354.27$ & $1,686.00$ & $4,332,000.00$ \\
Non interest expense & 114 & $321,169.96$ & $574,754.92$ & $22,323.00$ & $4,261,000.00$ \\
Net interest income & 115 & $222,917.22$ & 249575.88 & 13119.00 & 1172000.00 \\
Off balance sheet & 106 & $1,349,120.02$ & $1,777,397.44$ & 0.00 & $8,320,000.00$ \\
activity & & \multicolumn{5}{|c}{} \\
\hline
\end{tabular}

Panel D: Foreign Banks.

\begin{tabular}{|l|c|c|c|c|c|}
\hline \multicolumn{1}{|c|}{ Variable } & Observations & Mean & Std Deviation & Minimum & Maximum \\
\hline Deposits & 111 & $1,621,790.23$ & $1,920,254.21$ & $95,779.00$ & $10,029,900.00$ \\
Employees & 107 & 648.35 & 825.43 & 45.00 & $2,997.00$ \\
Equity capital & 111 & $284,274.48$ & $337,204.36$ & $25,234.00$ & $1,576,769.00$ \\
Housing loans & 108 & $417,756.67$ & $1,180,123.85$ & 0.00 & $6,441,200.00$ \\
Interest expense & 110 & $214,613.20$ & $198,050.22$ & $21,495.00$ & $942,920.00$ \\
Investments & 111 & $816,817.88$ & $996,728.55$ & $2,701.00$ & $5,051,666.00$ \\
Loans & 111 & $2,102,252.76$ & $2,484,295.35$ & $300,490.00$ & $14,256,200.00$ \\
Non interest income & 101 & $69,777.28$ & $120,381.35$ & $2,122.00$ & $580,546.00$ \\
Non interest expense & 76 & $106,154.38$ & $120,140.24$ & $8,431.00$ & $568,218.00$ \\
Net interest income & 110 & $64,614.22$ & $90,084.32$ & -856.00 & $369,000.00$ \\
Off balance sheet & 110 & $678,409.36$ & $860,514.50$ & $5,772.00$ & $5,086,258.00$ \\
activity & & & & & \\
\hline
\end{tabular}

\section{Results.}

The DEA and Malmquist Index estimation used in this study is input oriented, which addresses the issue of reducing input quantities proportionally while keeping output quantities unchanged. Summaries of the results of the input-oriented DEA efficiency scores for Model 1 for each year in the sample period are shown in Table 4, while Figure 1 graphs the summaries drawn from Table $4 .{ }^{34}$ Average Technical Efficiency ranges from 0.73 (1991) to 0.94 (2000). These values are higher than those found by Sathye (2001), who estimated an overall efficiency score of 0.58 for 1996. However, Avkiran (1999) found annual mean efficiency scores of between 0.80 (1991) to 0.91 (1986). As stated by Berger et al (1993), results of efficiency estimations are sensitive to the specification of inputs and outputs, even when the same method of estimation is applied. Thus care should be taken when comparing efficiency scores drawn from different samples (even if the same estimation method has been used). Sathye (2001) used labour, the price of labour, capital, the price of capital, loanable funds

34 Summaries of the DEA efficiency scores for Models 1a, $1 \mathrm{~b}$ and 2 are in the Appendix of this paper as Tables A4 to A6 respectively. 
and the price of loanable funds as inputs, while using demand deposits and loans as outputs. ${ }^{35}$ This is a different specification to that applied in this study, which is the likely source of differences between the two sets of results. Berger and Humphrey (1997) found world mean efficiency of 0.86, which is similar to the range of values found in all models in this study. Further, Allen and Rai (1996) conducted a cross-nation study of bank efficiency and found Australian bank efficiency of similar magnitude to that found in this study. ${ }^{36}$ With average input efficiency in this study of around $80 \%$, this indicates that the Australian banking system could reduce inputs by approximately $25 \%$ without changing output levels.

Table 4.

Average DEA Efficiency Scores: Model 1 (standard deviations in parentheses)

\begin{tabular}{|l|c|c|c|}
\hline Year & \multicolumn{3}{|l|}{} \\
\hline $\mathbf{1 9 8 8}$ & TE & PTE & Scale \\
\hline All & $0.74^{*}$ & $0.89^{*}$ & $0.93^{*}$ \\
& $(0.22)$ & $(0.14)$ & $(0.24)$ \\
Big 4 & 0.62 & $\mathbf{1 . 0 0}^{*}$ & 0.62 \\
& $(0.10)$ & $(0.00)$ & $(0.10)$ \\
ODOM & $\mathbf{0 . 7 6}^{*}$ & $0.88^{*}$ & $\mathbf{1 . 1 5}^{*}$ \\
& $(0.28)$ & $(0.13)$ & $(0.21)$ \\
Foreign & $0.75^{*}$ & $0.88^{*}$ & $0.92^{*}$ \\
& $(0.23)$ & $(0.16)$ & $(0.21)$ \\
\hline
\end{tabular}

\begin{tabular}{|l|c|c|c|}
\hline Year & \multicolumn{3}{|l|}{} \\
\hline \multicolumn{1}{|c|}{ 1989 } & TE & PTE & Scale \\
\hline All & $0.76^{*}$ & $0.89^{*}$ & $0.94^{*}$ \\
& $(0.21)$ & $(0.18)$ & $(0.20)$ \\
Big 4 & 0.65 & $\mathbf{0 . 9 7} *$ & 0.67 \\
& $(0.07)$ & $(0.06)$ & $(0.08)$ \\
ODOM & $0.75^{*}$ & $0.87^{*}$ & $0.96^{*}$ \\
& $(0.22)$ & $(0.20)$ & $(0.19)$ \\
Foreign & $\mathbf{0 . 7 9}^{*}$ & $0.89^{*}$ & $\mathbf{0 . 9 8}^{*}$ \\
& $(0.22)$ & $(0.19)$ & $(0.18)$ \\
\hline
\end{tabular}

\begin{tabular}{|l|c|c|c|}
\hline 1990 & TE & PTE & Scale \\
\hline All & $0.75^{*}$ & $0.89^{*}$ & $0.94^{*}$ \\
& $(0.21)$ & $(0.19)$ & $(0.21)$ \\
Big 4 & 0.61 & $\mathbf{0 . 9 6 *}$ & 0.64 \\
& $(0.09)$ & $(0.06)$ & $(0.08)$ \\
ODOM & $0.73^{*}$ & $0.82^{*}$ & $0.92^{*}$ \\
& $(0.16)$ & $(0.18)$ & $(0.16)$ \\
Foreign & $\mathbf{0 . 8 0 *}$ & $0.92^{*}$ & $\mathbf{1 . 0 3}^{*}$ \\
& $(0.24)$ & $(0.21)$ & $(0.20)$ \\
\hline
\end{tabular}

\begin{tabular}{|l|c|c|c|}
\hline $\mathbf{1 9 9 1}$ & TE & PTE & Scale \\
\hline All & $0.73^{*}$ & $0.86^{*}$ & $0.93^{*}$ \\
& $(0.21)$ & $(0.22)$ & $(0.20)$ \\
Big 4 & 0.71 & $\mathbf{0 . 9 6}^{*}$ & 0.73 \\
& $(0.09)$ & $(0.07)$ & $(0.06)$ \\
ODOM & $0.66^{*}$ & $0.80^{*}$ & $0.86^{*}$ \\
& $(0.18)$ & $(0.23)$ & $(0.18)$ \\
Foreign & $\mathbf{0 . 7 8}^{*}$ & $0.88^{*}$ & $\mathbf{1 . 0 3}^{*}$ \\
& $(0.25)$ & $(0.24)$ & $(0.18)$ \\
\hline
\end{tabular}

\begin{tabular}{|l|c|c|c|}
\hline 1992 & TE & PTE & Scale \\
\hline All & $0.79^{*}$ & $0.91^{*}$ & $0.94^{*}$ \\
& $(0.18)$ & $(0.16)$ & $(0.18)$ \\
Big 4 & 0.79 & $\mathbf{0 . 9 8} *$ & 0.81 \\
& $(0.14)$ & $(0.04)$ & $(0.12)$ \\
ODOM & $0.74^{*}$ & $0.89^{*}$ & $0.88^{*}$ \\
& $(0.18)$ & $(0.13)$ & $(0.20)$ \\
Foreign & $\mathbf{0 . 8 2}^{*}$ & $0.89^{*}$ & $\mathbf{1 . 0 3}^{*}$ \\
& $(0.21)$ & $(0.20)$ & $(0.13)$ \\
\hline
\end{tabular}

\begin{tabular}{|l|c|c|c|}
\hline 1993 & TE & PTE & Scale \\
\hline All & $0.78^{*}$ & $0.90^{*}$ & $0.90^{*}$ \\
& $(0.19)$ & $(0.17)$ & $(0.18)$ \\
Big 4 & 0.71 & $\mathbf{0 . 9 6}^{*}$ & 0.74 \\
& $(0.05)$ & $(0.09)$ & $(0.03)$ \\
ODOM & $0.77^{*}$ & $0.92^{*}$ & $0.85^{*}$ \\
& $(0.19)$ & $(0.13)$ & $(0.20)$ \\
Foreign & $\mathbf{0 . 8 1 *}$ & $0.86^{*}$ & $\mathbf{1 . 0 0 *}$ \\
& $(0.23)$ & $(0.22)$ & $(0.13)$ \\
\hline
\end{tabular}

35 By using the price of inputs as well as their quantities, Sathye (2001) was able to measure allocative efficiency. Due to data availability, this was not possible for the much larger sample used in this study.

36 Allen and Rai (1996) reported average bank inefficiency scores for Australia of 0.134, implying bank efficiency scores of 0.866 . 


\begin{tabular}{|l|c|c|c|}
\hline $\mathbf{1 9 9 4}$ & TE & PTE & Scale \\
\hline All & $0.75^{*}$ & $0.93^{*}$ & $0.84^{*}$ \\
& $(0.22)$ & $(0.16)$ & $(0.21)$ \\
Big 4 & 0.67 & $\mathbf{0 . 9 9 *}$ & 0.68 \\
& $(0.07)$ & $(0.02)$ & $(0.07)$ \\
ODOM & $\mathbf{0 . 8 0}^{*}$ & $0.93^{*}$ & $\mathbf{0 . 8 7 *}$ \\
& $(0.12)$ & $(0.11)$ & $(0.11)$ \\
Foreign & $0.74^{*}$ & $0.90^{*}$ & $0.86^{*}$ \\
& $(0.31)$ & $(0.22)$ & $(0.28)$ \\
\hline
\end{tabular}

\begin{tabular}{|l|c|c|c|}
\hline 1995 & TE & PTE & Scale \\
\hline All & $0.78^{*}$ & $0.92^{*}$ & $0.87^{*}$ \\
& $(0.21)$ & $(0.11)$ & $(0.20)$ \\
Big 4 & $\mathbf{0 . 8 1}$ & $\mathbf{0 . 9 9 *}$ & $0.82^{*}$ \\
& $(0.13)$ & $(0.03)$ & $(0.11)$ \\
ODOM & 0.76 & $0.88^{*}$ & $0.87^{*}$ \\
& $(0.13)$ & $(0.13)$ & $(0.10)$ \\
Foreign & $0.79^{*}$ & $0.93^{*}$ & $\mathbf{0 . 8 8}$ \\
& $(0.30)$ & $(0.10)$ & $(0.30)$ \\
\hline
\end{tabular}

\begin{tabular}{|l|c|c|c|}
\hline 1996 & TE & PTE & Scale \\
\hline All & $0.84^{*}$ & $0.96^{*}$ & $0.93^{*}$ \\
& $(0.12)$ & $(0.06)$ & $(0.17)$ \\
Big 4 & 0.78 & $0.98^{*}$ & 0.79 \\
& $(0.14)$ & $(0.04)$ & $(0.13)$ \\
ODOM & 0.81 & $0.94^{*}$ & $0.94^{*}$ \\
& $(0.11)$ & $(0.08)$ & $(0.17)$ \\
Foreign & $\mathbf{0 . 9 2 *}$ & $\mathbf{0 . 9 9 *}$ & $\mathbf{1 . 0 2} *$ \\
& $(0.12)$ & $(0.03)$ & $(0.13)$ \\
\hline
\end{tabular}

\begin{tabular}{|l|c|c|c|}
\hline 1997 & TE & PTE & Scale \\
\hline All & $0.79^{*}$ & $0.93^{*}$ & $0.89^{*}$ \\
& $(0.21)$ & $(0.15)$ & $(0.19)$ \\
Big 4 & $0.81^{*}$ & $\mathbf{1 . 0 0}^{*}$ & $0.81^{*}$ \\
& $(0.13)$ & $(0.00)$ & $(0.13)$ \\
ODOM & 0.77 & $0.93^{*}$ & $\mathbf{0 . 9 3}$ \\
& $(0.18)$ & $(0.14)$ & $(0.21)$ \\
Foreign & $\mathbf{0 . 8 0 *}$ & $0.89^{*}$ & $0.90^{*}$ \\
& $(0.29)$ & $(0.20)$ & $(0.20)$ \\
\hline
\end{tabular}

\begin{tabular}{|l|c|c|c|}
\hline $\mathbf{1 9 9 8}$ & TE & PTE & Scale \\
\hline All & $0.87^{*}$ & $0.96^{*}$ & $0.96^{*}$ \\
& 0.15 & 0.12 & 0.13 \\
Big 4 & $0.87^{*}$ & $\mathbf{1 . 0 0}^{*}$ & $0.87^{*}$ \\
& 0.09 & 0.00 & 0.09 \\
ODOM & 0.80 & $0.91^{*}$ & 0.97 \\
& 0.21 & 0.20 & 0.16 \\
Foreign & $\mathbf{0 . 9 5}^{*}$ & $\mathbf{1 . 0 0}^{*}$ & $\mathbf{1 . 0 5}^{*}$ \\
& 0.10 & 0.01 & 0.09 \\
\hline
\end{tabular}

\begin{tabular}{|l|c|c|c|}
\hline 1999 & TE & PTE & Scale \\
\hline All & $0.86^{*}$ & $0.95^{*}$ & $0.97^{*}$ \\
& $(0.16)$ & $(0.10)$ & $(0.16)$ \\
Big 4 & 0.90 & $\mathbf{1 . 0 0}^{*}$ & 0.90 \\
& $(0.14)$ & $(0.00)$ & $(0.14)$ \\
ODOM & $0.76^{*}$ & $0.88^{*}$ & $0.94^{*}$ \\
& $(0.17)$ & $(0.14)$ & $(0.17)$ \\
Foreign & $\mathbf{0 . 9 3}^{*}$ & $\mathbf{1 . 0 0}^{*}$ & $\mathbf{1 . 0 7 *}$ \\
& $(0.14)$ & $(0.00)$ & $(0.14)$ \\
\hline
\end{tabular}

\begin{tabular}{|l|c|c|c|}
\hline $\mathbf{2 0 0 0}$ & TE & PTE & Scale \\
\hline All & $0.94^{*}$ & $0.99^{*}$ & $0.95^{*}$ \\
& $(0.08)$ & $(0.03)$ & $(0.07)$ \\
Big 4 & $0.92^{*}$ & $\mathbf{1 . 0 0}^{*}$ & $0.92^{*}$ \\
& $(0.09)$ & $(0.00)$ & $(0.09)$ \\
ODOM & $0.93^{*}$ & $0.98^{*}$ & $0.95^{*}$ \\
& $(0.09)$ & $(0.04)$ & $(0.06)$ \\
Foreign & $\mathbf{1 . 0 0}^{*}$ & $\mathbf{1 . 0 0 *}$ & $\mathbf{1 . 0 0 *}$ \\
& $(0.00$ & $(0.00)$ & $(0.00)$ \\
\hline
\end{tabular}

\begin{tabular}{|l|c|c|c|}
\hline 2001 & TE & PTE & Scale \\
\hline All & $0.93^{*}$ & $0.96^{*}$ & $0.98^{*}$ \\
& $(0.09)$ & $(0.06)$ & $(0.06)$ \\
Big 4 & $0.94^{*}$ & $0.99^{*}$ & $0.95^{*}$ \\
& $(0.07)$ & $(0.03)$ & $(0.06)$ \\
ODOM & $0.91^{*}$ & $0.94^{*}$ & $\mathbf{1 . 0 0}^{*}$ \\
& $(0.11)$ & $(0.08)$ & $(0.06)$ \\
Foreign & $\mathbf{1 . 0 0}^{*}$ & $\mathbf{1 . 0 0}^{*}$ & $\mathbf{1 . 0 0}^{*}$ \\
& $(0.00)$ & $(0.00)$ & $(0.00)$ \\
\hline
\end{tabular}

Model 1: Inputs: (i) employees, (ii) deposits, (iii) equity capital. Outputs: (i) loans, (ii) off balance sheet items. TE: Technical Efficiency, PTE: Pure Technical Efficiency, Scale: Scale Efficiency. ODOM: Other Domestic. Values in bold are the largest for that category in that year. * Indicates maximum value of 1 for that category.

Scale Efficiency is calculated as decreasing return to scale; scale efficiency score unchanged; constant returns to scale score unchanged; increasing returns to scale, score transformed to (2- original score). Thus, an average scale efficiency score above 1 indicates increasing returns to scale on average, below one indicates decreasing returns to scale on average and a score of one indicates constant returns to scale on average. 
Figure 1. Average DEA Efficiency Scores: Model 1, 1988 to 2001

\section{Technical Efficiency}

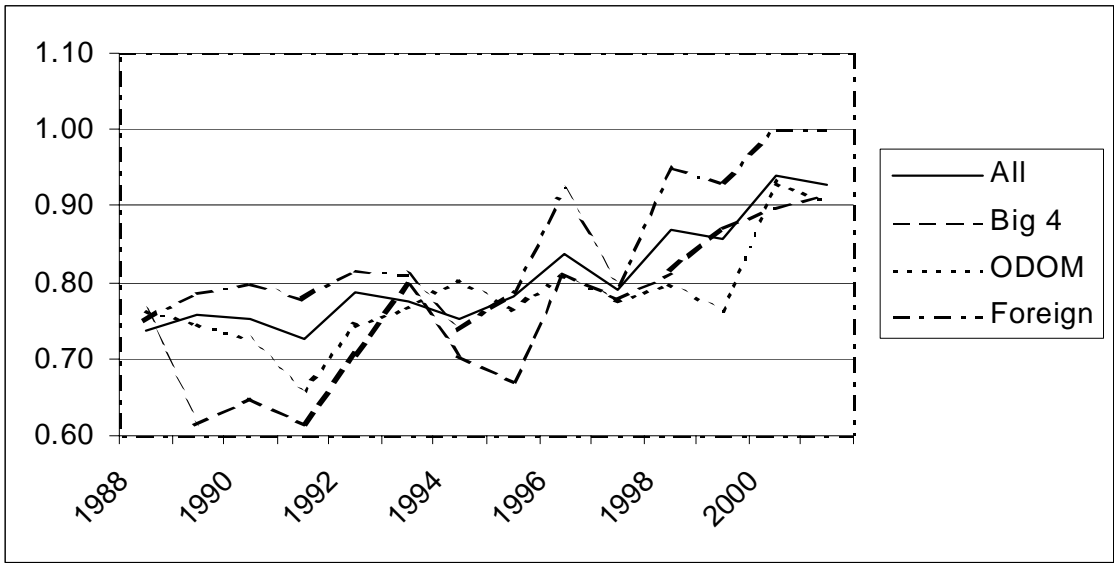

Pure Technical Efficiency

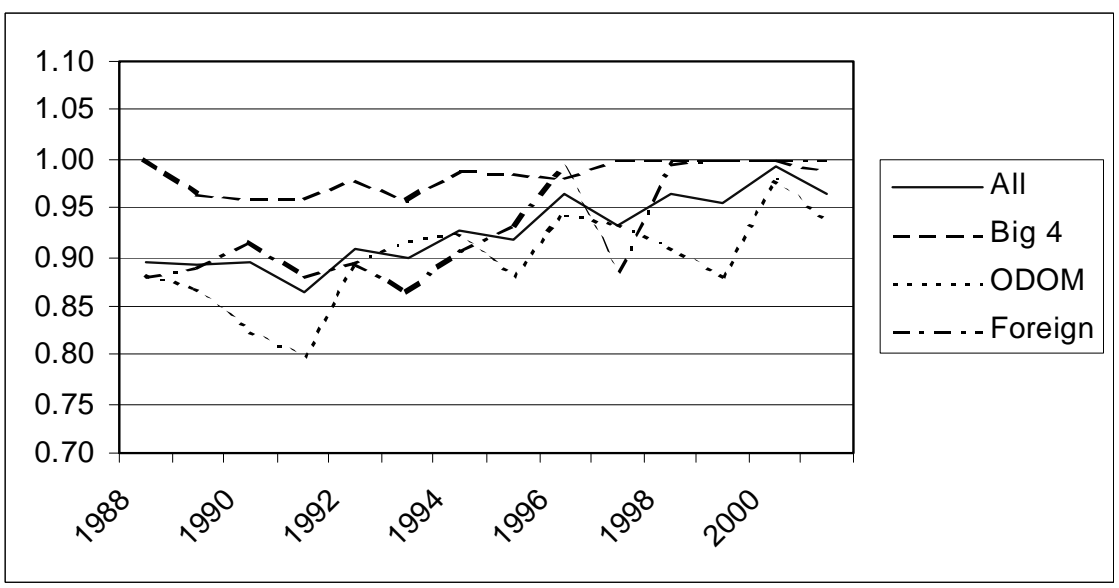

Scale Efficiency

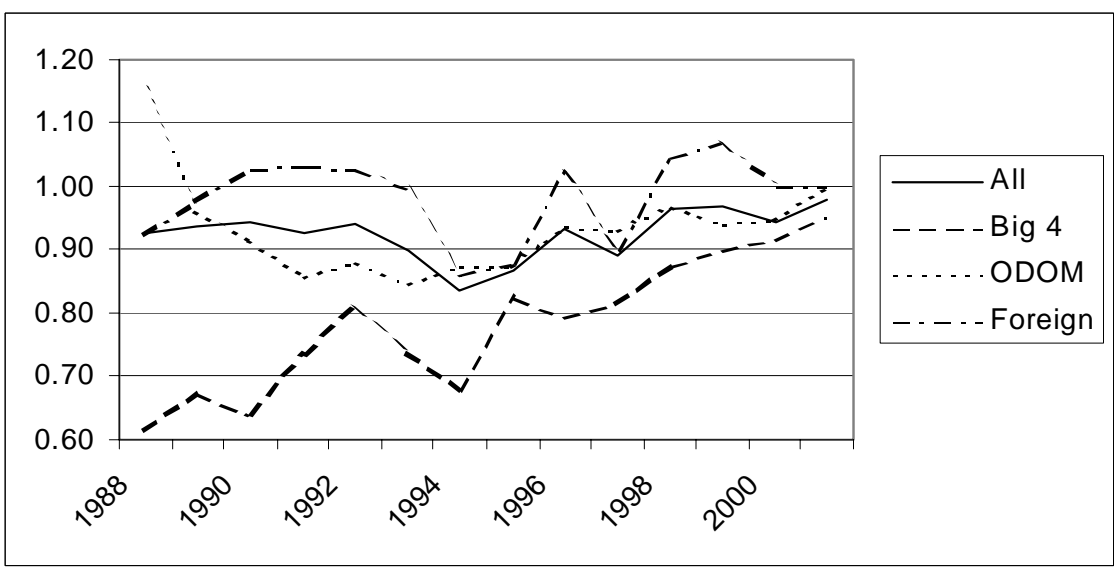

Model 1: Inputs: (i) employees, (ii) deposits, (iii) equity capital. Outputs: (i) loans, (ii) off balance sheet items. TE: Technical Efficiency, PTE: Pure Technical Efficiency, Scale: Scale Efficiency. ODOM: Other Domestic. Scale Efficiency is calculated as decreasing return to scale; scale efficiency score unchanged; constant returns to scale score unchanged; increasing returns to scale, score transformed to (2-original score). Thus, an average scale efficiency score above 1 indicates increasing returns to scale on average, below one indicates decreasing returns to scale on average and a score of one indicates constant returns to scale on average. 
Examination of Table 4 indicates the main source of technical inefficiency is scale inefficiency, with scale efficiency ranging between 0.84 (1994) and 0.99 (2001). This is in contrast to the results of Allen and Rai (1996) who found - in a global context - that input X-inefficiencies, such as technical inefficiencies, dominated output inefficiencies, such as economies of scope, when determining overall efficiency. Closer examination of these results shows that the Big Four banks have consistently lower scale efficiency. However, the Big Four banks also have consistently higher pure technical efficiency. Thus, the Big Four banks are operating at a scale size in excess of that for optimum technical efficiency. This result supports the arguments of Stearn and Hall (1983) and Hall (1987), that the mergers amongst the major banks during the deregulation period were defensive reactions to foreign bank entry, with the major banks seeking to use size as a barrier to entry to the new entrants. Further, Ferguson (1990) argued that the four major banks increased spending on branch infrastructure with the same aim. It can be seen from this study that the impact of this strategy was to expand the major banks to a size beyond that needed for efficient operation. This can be seen most strongly when considering the results for Model 1a, both the DEA and Malmquist results do not find the Big Four banks to be the most efficient on average, with the sole exception of 1999 (DEA). This would indicate that the use of size as a barrier to entry was most reflected in the branch networks employed in retail banking. It is interesting to note that in the later years of this study, one of the Big Four banks (ANZ) has adjusted its size to that of constant returns to scale (or most efficient scale size), for all DEA models. ${ }^{37}$ As discussed below, the Malmquist Index results find that the Big Four banks tended to improve their scale efficiency toward the end of the sample period, thus the scale inefficiencies of the immediate post-deregulation period are now declining. Table 5 summarises the scale efficiency for each year of the study from the DEA estimation. ${ }^{38}$

Table 5.

DEA Scale Efficiency: Model 1.

\begin{tabular}{|l|c|c|c|}
\hline Year & \multicolumn{3}{|l|}{} \\
\hline 1988 & DRS & IRS & CRS \\
All & 9 & 5 & 4 \\
Big 4 & 2 & 0 & 0 \\
ODOM & 0 & 2 & 1 \\
Foreign & 7 & 3 & 3 \\
\hline
\end{tabular}

\begin{tabular}{|l|c|c|c|}
\hline Year & \multicolumn{3}{|l|}{} \\
\hline 1989 & DRS & IRS & CRS \\
All & 13 & 7 & 6 \\
Big 4 & 3 & 0 & 0 \\
ODOM & 4 & 3 & 1 \\
Foreign & 6 & 4 & 5 \\
\hline
\end{tabular}

\begin{tabular}{|l|c|c|c|}
\hline 1990 & DRS & IRS & CRS \\
\hline All & 9 & 6 & 8 \\
Big 4 & 3 & 0 & 0 \\
ODOM & 3 & 2 & 2 \\
Foreign & 3 & 4 & 6 \\
\hline
\end{tabular}

\begin{tabular}{|l|c|c|c|}
\hline 1991 & DRS & IRS & CRS \\
\hline All & 11 & 7 & 8 \\
Big 4 & 4 & 0 & 0 \\
ODOM & 5 & 2 & 2 \\
Foreign & 2 & 5 & 6 \\
\hline
\end{tabular}

37 Sathye (2002) also found ANZ to show consistently high efficiency.

38 Scale efficiency for Models $1 \mathrm{a}, 1 \mathrm{~b}$ and 2 are in the Appendix as Tables A7 to A9 respectively. 


\begin{tabular}{|l|c|c|c|}
\hline 1992 & DRS & IRS & CRS \\
\hline All & 13 & 6 & 6 \\
Big 4 & 4 & 0 & 0 \\
ODOM & 7 & 1 & 1 \\
Foreign & 2 & 5 & 5 \\
\hline
\end{tabular}

\begin{tabular}{|l|c|c|c|}
\hline 1993 & DRS & IRS & CRS \\
\hline All & 12 & 5 & 7 \\
Big 4 & 4 & 0 & 0 \\
ODOM & 6 & 1 & 2 \\
Foreign & 2 & 4 & 5 \\
\hline
\end{tabular}

\begin{tabular}{|l|c|c|c|}
\hline 1994 & DRS & IRS & CRS \\
\hline All & 18 & 1 & 6 \\
Big 4 & 4 & 0 & 0 \\
ODOM & 9 & 0 & 1 \\
Foreign & 5 & 1 & 5 \\
\hline
\end{tabular}

\begin{tabular}{|l|c|c|c|}
\hline 1995 & DRS & IRS & CRS \\
\hline All & 16 & 1 & 6 \\
Big 4 & 3 & 0 & 1 \\
ODOM & 10 & 0 & 0 \\
Foreign & 3 & 1 & 5 \\
\hline
\end{tabular}

\begin{tabular}{|l|c|c|c|}
\hline 1996 & DRS & IRS & CRS \\
\hline All & 11 & 5 & 4 \\
Big 4 & 4 & 0 & 0 \\
ODOM & 5 & 4 & 1 \\
Foreign & 2 & 1 & 3 \\
\hline
\end{tabular}

\begin{tabular}{|l|c|c|c|}
\hline 1997 & DRS & IRS & CRS \\
\hline All & 8 & 5 & 4 \\
Big 4 & 3 & 0 & 1 \\
ODOM & 3 & 4 & 0 \\
Foreign & 2 & 1 & 3 \\
\hline
\end{tabular}

\begin{tabular}{|l|c|c|c|}
\hline 1998 & DRS & IRS & CRS \\
\hline All & 5 & 5 & 3 \\
Big 4 & 3 & 0 & 1 \\
ODOM & 2 & 3 & 0 \\
Foreign & 0 & 2 & 2 \\
\hline
\end{tabular}

\begin{tabular}{|l|c|c|c|}
\hline 1999 & DRS & IRS & CRS \\
\hline All & 6 & 3 & 4 \\
Big 4 & 4 & 0 & 0 \\
ODOM & 2 & 2 & 1 \\
Foreign & 0 & 1 & 3 \\
\hline
\end{tabular}

\begin{tabular}{|l|c|c|c|}
\hline 2000 & DRS & IRS & CRS \\
\hline All & 5 & 0 & 5 \\
Big 4 & 3 & 0 & 1 \\
ODOM & 2 & 0 & 2 \\
Foreign & 0 & 0 & 2 \\
\hline
\end{tabular}

\begin{tabular}{|l|c|c|c|}
\hline 2001 & DRS & IRS & CRS \\
\hline All & 4 & 1 & 5 \\
Big 4 & 2 & 0 & 2 \\
ODOM & 2 & 1 & 2 \\
Foreign & 0 & 0 & 1 \\
\hline
\end{tabular}

DRS: Decreasing Returns to Scale; IRS: Increasing Returns to Scale; CRS: Constant Returns to Scale.

Model 1: Inputs: (i) employees, (ii) deposits, (iii) equity capital. Outputs: (i) loans, (ii) off balance sheet items. ODOM: Other Domestic.

Considering the DEA results of Tables 4 and 5 in conjunction, the foreign banks generally display superior technical efficiency due to superior scale efficiency. This superior scale efficiency confirms the argument of the Reserve Bank of Australia (1994) that the foreign banks innately possess economies of scale and so were able to offer an immediate competitive stimulus to the Australian banking system. As Table 4 shows, in their first full year of operations, the foreign banks were, on average, more efficient than the Big Four banks. However, given the sample size and standard deviations, these differences are not significant. In the fourteen years considered by this study the foreign banks displayed superior average technical efficiency in eleven years. This outcome stands somewhat in contrast to the results surveyed by Berger et al (2000), which indicated that foreign banks are on average less efficient than domestic banks. The solution to this difference may be found in the limited form of the global advantage hypothesis proposed by Berger et al (2000), which argues that multinational banks from a subset of nations are able to operate in the host nation at superior efficiency. 
As shown in Table 1, the number of foreign banks considered in this study is relatively small, thus statistical testing of nation effects is not possible. The process by which these nations were selected is difficult to determine as it occurred during a closed session of the Federal Cabinet. However, this process did have a bias toward large established multinational banks from Australia's major trading partners (Pauly, 1987). It is possible that this bias has selected those banks that possess advantages that reflect some aspect of the limited form of the global advantage hypothesis. ${ }^{39}$

Consistent with the findings of Avkiran (1999), the DEA study finds that 1991 was the year of lowest average efficiency for most models. In 1991 increased provisions for bad debts were experienced by the Australian banking system. It is worthwhile noting that Model 1a, which has a retail focus, does not show 1991 to be the year of lowest average efficiency, indicating that those banks with a retail focus were able to reduce the negative impact of the losses of the early 1990s. It is also worth noting that Model 2, which has a revenue focus, shows 1993 as the year of lowest efficiency, indicating there are some delays in these losses being reflected in the revenue measures used. ${ }^{40}$

The Malmquist Index results found that the post-deregulation period studied was generally one of overall efficiency improvement, with Model 1 finding productivity improvements of $10 \%$ over the sample period. Model $1 \mathrm{~b}$ with a wholesale focus, found similar efficiency improvements. This outcome is weakly consistent with the arguments of Milbourne and Cumberworth (1991) who argued that the competitive impact of foreign bank entry in Australia was particularly apparent in the wholesale markets. It can be seen from Table 6 that the rate of technological change was lower in the retail focussed model (Model 1a), as compared to Models 1 and 1b. Model 1a found somewhat lower average improvements in efficiency, at $8 \%$, due to lower technological change. However, as shown in Table 2, the sample period for Model 1a differs from that of Models 1 and 1b. A notable result for the Malmquist Index Model 1a was a finding of very high technological change in 1992, particularly for the foreign banks (index value of 2.41 for foreign banks), this was followed by a large technological regress in 1994 for foreign banks (index value of 0.57). This rapid shift is possibly the result of the recession of the early 1990s impacting upon the pace of innovation. ${ }^{41}$ It is also highly likely that some of the foreign banks were adjusting their operations after 1993 to reflect the process of conversion to branch status, causing a shift in the input-output mix employed by the foreign subsidiary banks and a resulting reduction in observed efficiency.

In contrast, Model 2 concluded that there was productivity regress of 3\% over the sample period, while Avkiran (2000) found productivity improvement of 3.5\%. While Avkiran (2000) specified the same inputs and outputs, fewer banks and a different sample period were used, which most likely accounts for the differences in results. The inclusion of foreign banks in this study, as opposed to Avkiran (2000) is the most likely source of this difference, with the foreign banks in Australia most impacted by the recession of the early 1990s in terms of profit reductions (Ferguson, 1990; Williams,

39 Suggestive of this conclusion is that IBJ and Mitsubishi Bank (later Bank of Tokyo/Mitsubishi) are consistently found to have technical efficiency of 1 in each of Models 1, 1a, and 1b. Given the small number of foreign banks in the study, a statistical test of the limited form of the global advantage hypothesis is not possible.

40 As the revenue measures employed excluded an asset quality measure.

41 This large cyclical effect also explains the large standard deviations seen in Model 1a in Table 6. It should be noted that the economic cycle effects of the early 1990s were not isolated to Australia. 
2002). Model 1 and its variations confirm Avkiran's (2000) result of productivity improvements being mainly sourced in technological progress. However, Model 2 in this study, as based upon Avkiran (2000), found technological regress and any small productivity improvements being sourced in scale efficiency changes, mainly for the Other Domestic banks. Table 6 has the summary of the Malmquist index means for all models. The Malmquist Indices for Model 1, Model 1a and Model 1b show foreign bank efficiency improving over the sample period, mainly due to technological change. However, Model 2 finds efficiency regress for the foreign banks over the sample period. This confirms that Model 2 measures different aspects of efficiency as compared to the other Models, as will be discussed below. It is worth noting that Demirgüc-Kunt and Huizinga (2001) argue that balance sheet measures are a more reliable measure of multinational bank activity than income items, in contrast to Berger et al (2000) who did not consider that observed differences in foreign bank efficiency were due to transfer pricing.

Table 6.

Malmquist Index Means

Model 1

\begin{tabular}{|l|c|c|c|c|c|}
\hline & Effch & Techch & Pech & Sech & Tfpch \\
\hline All & 0.98 & 1.12 & 1.00 & 0.98 & 1.10 \\
(Std Dev) & $(0.16)$ & $(0.25)$ & $(0.02)$ & $(0.17)$ & $(0.29)$ \\
Big 4 & 0.98 & $\mathbf{1 . 1 7}$ & $\mathbf{1 . 0 0}$ & 0.98 & $\mathbf{1 . 1 5}$ \\
(Std Dev) & $(0.26)$ & $(0.42)$ & $(0.04)$ & $(0.26)$ & $(0.35)$ \\
Other Domestic & 0.98 & 1.11 & $\mathbf{1 . 0 0}$ & 0.98 & 1.09 \\
(Std Dev) & $(0.12)$ & $(0.21)$ & $(0.04)$ & $(0.18)$ & $(0.13)$ \\
Foreign & $\mathbf{0 . 9 9}$ & 1.11 & $\mathbf{1 . 0 0}$ & $\mathbf{0 . 9 9}$ & 1.10 \\
(Std Dev) & $(0.19)$ & $(0.27)$ & $(0.03)$ & $(0.19)$ & $(0.56)$ \\
\hline
\end{tabular}

Model 1: Inputs: (i) employees, (ii) deposits, (iii) equity capital. Outputs: (i) loans, (ii) off balance sheet items.

Model 1a

\begin{tabular}{|l|c|c|c|c|c|}
\hline & Effch & Techch & Pech & Sech & Tfpch \\
\hline All & 1.00 & 1.09 & 1.00 & 1.00 & 1.08 \\
(Std Dev) & $(0.12)$ & $(0.55)$ & $(0.09)$ & $(0.12)$ & $(1.18)$ \\
Big 4 & 0.98 & 0.94 & 0.99 & 0.99 & 0.92 \\
(Std Dev) & $(0.0 .5)$ & $(0.36)$ & $(0.02)$ & $(0.02)$ & $(0.35)$ \\
Other Domestic & $\mathbf{1 . 0 0}$ & 1.04 & $\mathbf{1 . 0 0}$ & $\mathbf{1 . 0 0}$ & 1.04 \\
(Std Dev) & $(0.22)$ & $(0.54)$ & $(0.01)$ & $(0.19)$ & $(1.62)$ \\
Foreign & $\mathbf{1 . 0 0}$ & $\mathbf{1 . 2 0}$ & $\mathbf{1 . 0 0}$ & $\mathbf{1 . 0 0}$ & $\mathbf{1 . 2 0}$ \\
(Std Dev) & $(0.10)$ & $(0.59)$ & $(0.14)$ & $(0.14)$ & $(1.02)$ \\
\hline
\end{tabular}

Model 1a: Inputs: (i) employees, (ii) deposits, (iii) equity capital. Outputs: (i) loans less housing loans, (ii) housing loans (iii) off balance sheet items. 


\section{Model 1b}

\begin{tabular}{|l|c|c|c|c|c|}
\hline & Effch & Techch & Pech & Sech & Tfpch \\
\hline All & 0.98 & 1.12 & 1.00 & 0.98 & 1.10 \\
(Std Dev) & $(0.05)$ & $(0.24)$ & $(0.02)$ & $(0.06)$ & $(0.25)$ \\
Big 4 & 0.98 & 1.12 & $\mathbf{1 . 0 0}$ & 0.98 & 1.09 \\
(Std Dev) & $(0.15)$ & $(0.34)$ & $(0.04)$ & $(0.07)$ & $(0.34)$ \\
Other Domestic & 0.98 & 1.09 & $\mathbf{1 . 0 0}$ & 0.98 & 1.08 \\
(Std Dev) & $(0.04)$ & $(0.22)$ & $(0.04)$ & $(0.03)$ & $(0.25)$ \\
Foreign & $\mathbf{0 . 9 9}$ & $\mathbf{1 . 1 4}$ & $\mathbf{1 . 0 0}$ & $\mathbf{0 . 9 9}$ & $\mathbf{1 . 1 2}$ \\
(Std Dev) & $(0.07)$ & $(0.26)$ & $(0.02)$ & $(0.07)$ & $(0.28)$ \\
\hline
\end{tabular}

Model 1b Inputs: (i) employees, (ii) deposits, (iii) equity capital. Outputs: (i) loans, (ii) investments, (iii) off balance sheet items.

Model 2

\begin{tabular}{|l|c|c|c|c|c|}
\hline & Effch & Techch & Pech & Sech & Tfpch \\
\hline All & 0.99 & 0.98 & 0.99 & 1.00 & 0.97 \\
(Std Dev) & $(0.09)$ & $(0.11)$ & $(0.04)$ & $(0.12)$ & $(0.28)$ \\
\hline Big 4 & $\mathbf{0 . 9 9}$ & $\mathbf{1 . 0 1}$ & $\mathbf{1 . 0 0}$ & 0.99 & $\mathbf{1 . 0 0}$ \\
(Std Dev) & $(0.17$ & $(0.11)$ & $(0.06)$ & $(0.15)$ & $(0.31)$ \\
\hline Other Domestic & $\mathbf{0 . 9 9}$ & 0.98 & 0.99 & $\mathbf{1 . 0 1}$ & 0.97 \\
(Std Dev) & $(0.08)$ & $(0.14)$ & $(0.03)$ & $(0.09)$ & $(0.14)$ \\
\hline Foreign & $\mathbf{0 . 9 9}$ & 0.96 & 0.99 & 1.00 & 0.94 \\
(Std Dev) & $(0.18)$ & $(0.09)$ & $(0.13)$ & $(0.22)$ & $(0.52)$ \\
\hline
\end{tabular}

Model 2: Inputs: (i) interest expenses, (ii) non-interest expenses. Outputs: (i) net interest income, (ii) noninterest income.

Values in bold are the largest for that category.

Effch: technical efficiency change relative to constant returns to scale technology. Techch: technological change. Pech: pure technical efficiency change relative to variable returns to scale technology. Sech: scale efficiency change. Tfpch: total factor productivity change. Effch $=$ Pech $*$ Sech. Tfpch $=$ Effch $*$ Techch.

(There are some small differences due to rounding.)

Model 2 is the revenue-focussed model and the Malmquist Indices indicate that improvement in efficiency found in the Models 1, 1a and 1b did not necessarily translate into improvements in observed profitability. This difference is most likely due to the impact of the economic recession of 1991 and 1992 upon the profits of banks in this study, as previously discussed. This point is borne out by considering a diagram of the annual Malmquist index results on a year-by-year basis. The yearly Malmquist index scores for Model 1 for each of technical efficiency change, technological change, pure technical efficiency change, scale efficiency change and total factor productivity change are graphed in Figure $2 .^{42}$ The graph shows that the early 1990s saw a distinct shift in efficiency changes, particularly for technological change, with the later period of the sample showing efficiency regress

42 Tables A10, A11, A12 and A13 have the year by year Malmquist index scores for, respectively, Model 1, Model 1a, Model $1 \mathrm{~b}$ and Model 2. 
due mainly to technological regress. The period immediately after deregulation saw rapid technological innovation resulting from the competitive shock, consistent with Claessens et al (2001). It was argued by Claessens et al (2001) that the competitive impact of foreign bank entry is felt immediately after entry, with the incumbent banks competing aggressively with the new entrants. The results of this study support this conclusion. The exogenous shocks of the recession of the early 1990s reversed many of these early benefits and slowed the pace of efficiency change (this was particularly apparent for the Malmquist Index results for foreign banks in Model 1a). However, the post-recession period also saw some small increases in scale efficiency changes. This period also saw a period of consolidation of the banking system in Australian brought on by both in-market mergers ${ }^{43}$ and some mergers of foreign bank parents. ${ }^{44}$

Figure 2.

Average Malmquist Index Scores Scores: Model 1. Efficiency Change

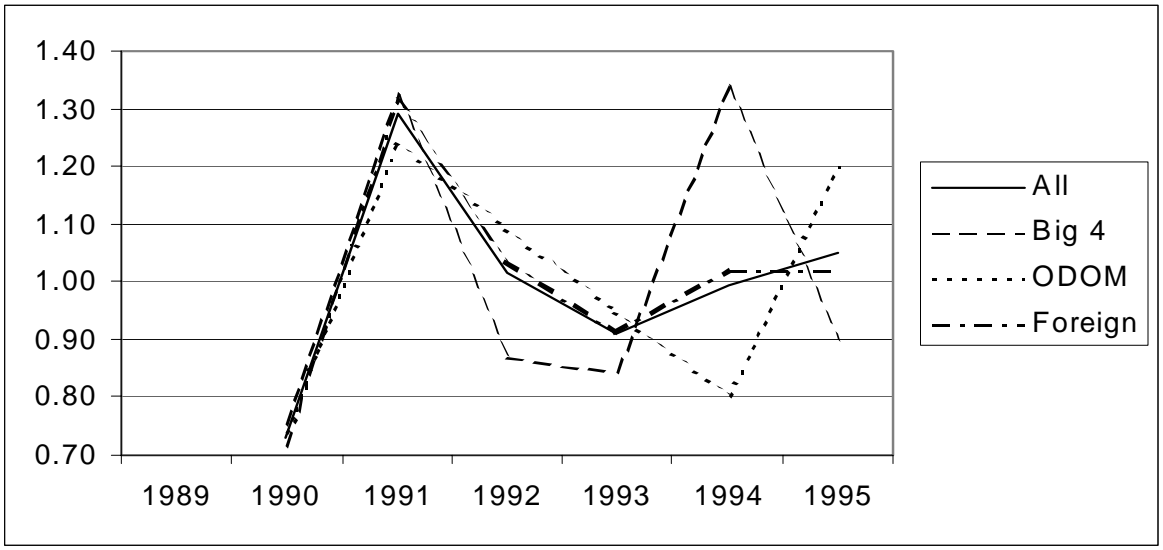

Technological Change

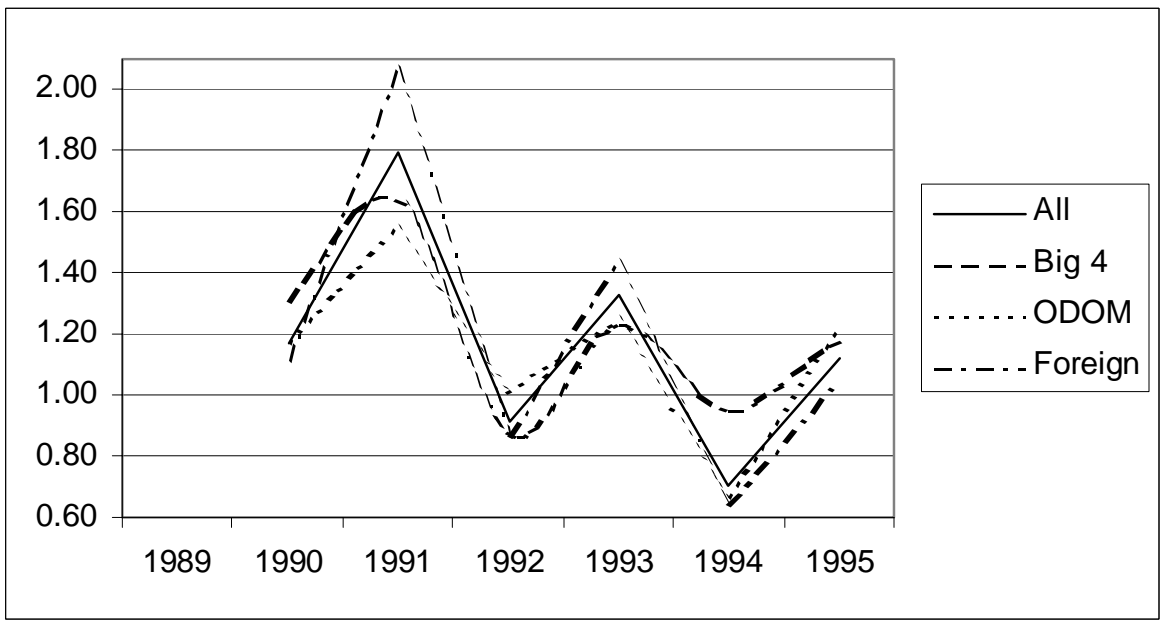

43 See Avkiran (1999).

44 It is possible that these mergers (both in market and of foreign bank parents) resulted in the post-recession improvements in scale efficiency, but sample size limitations prevent a conclusive test. Avkiran (1999) was likewise unable to conclusively discern a post-merger change in efficiency for individual banks. 
Pure Technical Efficiency Change

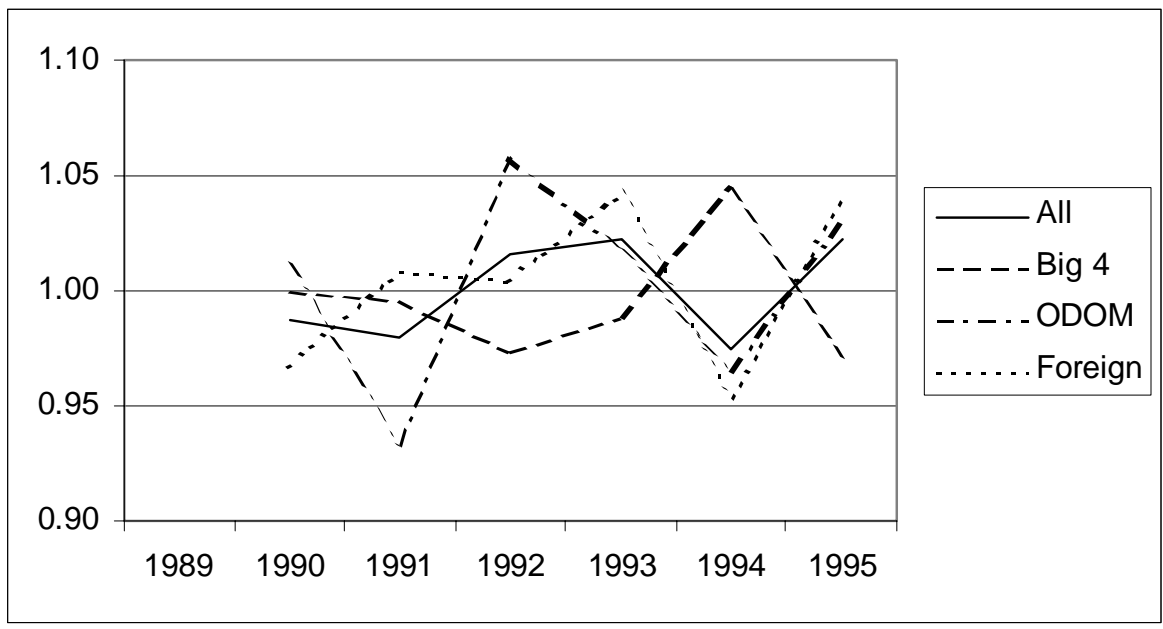

Scale Efficiency Change

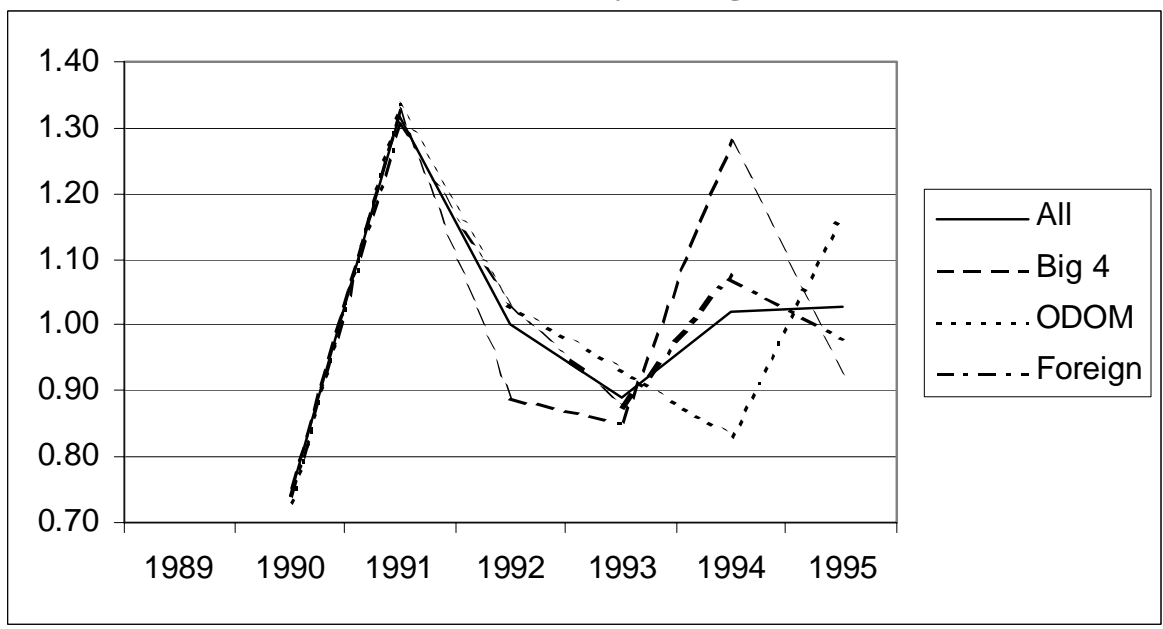

Total Factor Productivity Change

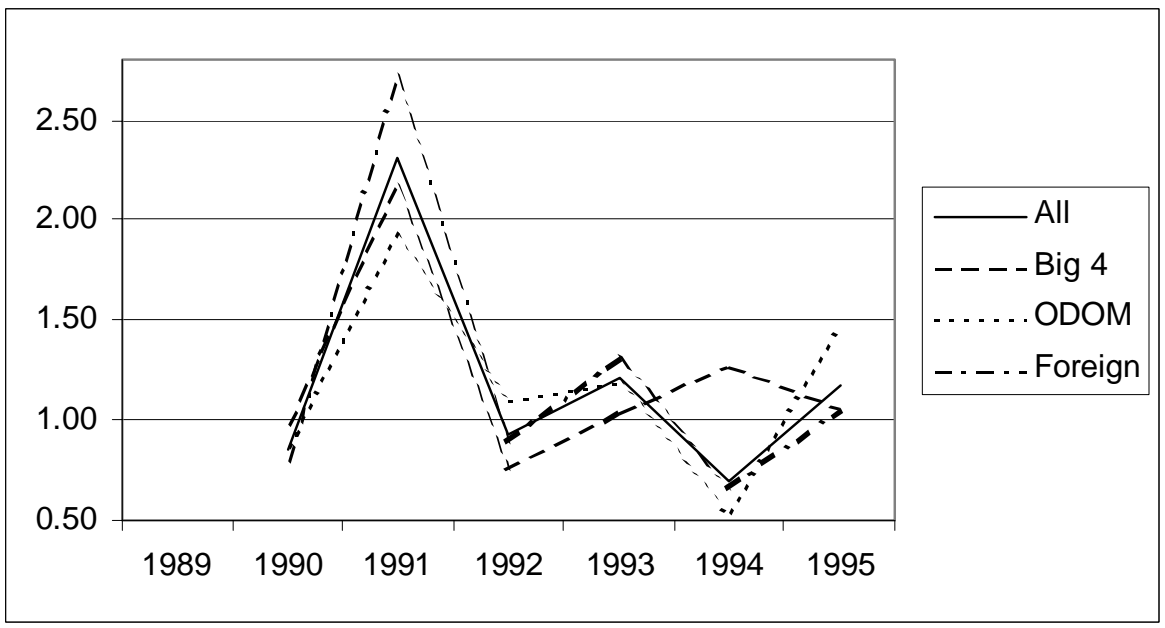

Model 1: Inputs: (i) employees, (ii) deposits, (iii) equity capital. Outputs: (i) loans, (ii) off balance sheet items. Effch: technical efficiency change relative to constant returns to scale technology. Techch: technological change. Pech: pure technical efficiency change relative to variable returns to scale technology. Sech: scale efficiency change. Tfpch: total factor productivity change. Effch $=$ Pech $*$ Sech. Tfpch $=$ Effch $*$ Techch. 
Overall, the Malmquist Index results do not show any one category of bank type as being conclusively more efficient. The Foreign banks are the most efficient in Models 1a and 1b, while Models 1 and 2 favour the Big Four banks. However, given the sample sizes and standard deviations, this cannot be considered conclusive. Study of the year by year results for the Malmquist indices found that as one category innovated to move the efficient frontier outward, the other categories reacted by innovating themselves and so moving the efficient frontier outward in following year. This explains why the averages are relatively close across the three bank categories across the sample periods, with the exception of Model 1a. As an example of this process, in 1991 the Foreign banks showed the largest efficiency improvements, while in 1992 it was the Other Domestic banks, in 1993 it was the Foreign banks, and in 1994 it was the Big Four banks (Model 1). As a result no one bank category alone dominated the Malmquist Index scores as being the source of efficiency improvements. This indicates the need for diversity in the types of banks operating in Australia in order to provide the competitive pressure to innovate and provide efficiency improvements.

Further, the results indicate the importance of negative external shocks, such as the recession of the early 1990s, in slowing down this process of innovation. It is also possible that the consolidation of the banking system that occurred in the mid to late 1990s contributed to this slowdown in efficiency changes. However, these mergers may have also resulted in a shift of emphasis from technological change to scale efficiency, but this result is somewhat less conclusive. As discussed below, over the study period a number of foreign banks converted to branch status, for which no data was available, and this lack of data may also act as a partial explanation of these results.

Over the sample period, the number of foreign subsidiary banks in the DEA sample declined. This was due to several factors. Firstly, there were mergers amongst the parent banks, with for example, Bank of Tokyo and Mitsubishi merging. The second factor was the restructure of Australian operations. As indicated in Section 2, in 1992 branch operations by foreign banks was permitted. As discussed by Davis and Lewis (1982) foreign banks prefer to operate in the host market as a branch, thus after some tax related issues were resolved (East, 1993), five foreign banks converted to branch status only. ${ }^{45}$ This factor is a likely explanation for the technological regress observed for Foreign banks in Model 1a in 1994. Given the difficulties mentioned above of comparing across separate DEA estimations, it is likely that those foreign banks that have made a strategic choice to operate in Australia as subsidiary banks rather than branches are those that are more efficient. While it is possible that the decline in sample size could also explain this effect, it is notable that the foreign banks consistently exhibit the best practice efficiency in the last two years of the sample, with the exception of Model 2. This would tend to support the limited version of the global advantage hypothesis proposed by Berger et al (2000). This is again an area that would benefit from further research.

As compared to the DEA results, the Malmquist results find little evidence of superior scale efficiency by the foreign banks, with overall scale efficiency changes for the period being close to 1 . Examination of Figure 2 finds a rapid improvement in scale efficiency in the early 1990s, followed by a rapid reduction, probably caused by the negative efficiency impact of the recession of the early 1990s. Following the recovery from this recession both of the domestic bank categories experienced

45 Some foreign banks operate in Australia as both subsidiary banks and branches. 
improvements in their scale efficiency, although the Big Four banks also experienced reduction in scale efficiency changes in the last sample year. This indicates that the shock of the recession of the early 1990s possibly produced a positive outcome of increased scale efficiency, although, as discussed above, the post-recession mergers are also possibly relevant, so this is not entirely conclusive. Combining this result with those from the DEA estimation, it can be concluded that the foreign banks provided an important source of technological efficiency changes immediately post-deregulation, and after the shock of the recession of the early 1990s the domestic banks somewhat improved their scale of operations.

Of the four DEA models of bank efficiency presented in this paper, Models 1, 1a and $1 \mathrm{~b}$ are relatively highly correlated, with the exception of Model 1a in 1988, and Model 1b in 1998. The low correlation for Model 1a in 1988 is due to sample availability issues. For the early period of this study the housing loans data needed for Model 1a was drawn from the Australian Government Gazette, which did not disclose housing loan data for trading banks, resulting in a smaller sample for this year. Model 2 has low or negative correlations with the other models except for 2001. This change (for 2001 only) is also most likely due to the impact of a reduction in sample size. Table 7 has correlation matrices for 1988 , 1993, 1998, and 2001.

Table 7.

Correlations between Alternative DEA Models.

Model 1

Model 1a

Model 1b

Model 2

Model 1

Model 1a

Model 1b

Model 2

Model 1

Model 1a

Model 1b

Model 2

Model 1

Model 1a

Model 1b

Model 2
1988

Technical Efficiency

$\begin{array}{cccc}\text { Model 1 } & \text { Model 1a } & \text { Model 1b } & \text { Model 2 } \\ 1.0000 & & & \\ 0.3560 & 1.0000 & & \\ 0.7575 & 0.5128 & 1.0000 & \\ -0.6111 & -0.1654 & -0.8418 & 1.0000\end{array}$

Pure Technical Efficiency / Scale Efficiency

$\begin{array}{cccc}\text { Model 1 } & \text { Model 1a } & \text { Model 1b } & \text { Model 2 } \\ 1.0000 & 0.5110 & 0.9103 & 0.2485 \\ 0.0000 & 1.0000 & 0.5736 & 0.5349 \\ 0.7104 & 0.0000 & 1.0000 & 0.2886 \\ -0.0724 & 0.0000 & -0.3476 & 1.0000 \\ & \mathbf{1 9 9 3} & & \\ & \text { Technical Efficiency } & & \text { Model 2 } \\ \text { Model 1 } & \text { Model 1a } & \text { Model 1b } & \\ 1.0000 & & & 1.0000 \\ 0.8382 & 1.0000 & & \\ 0.8212 & 0.5771 & 1.0000 & \\ -0.3763 & -0.4857 & -0.1260 & \end{array}$

Pure Technical Efficiency / Scale Efficiency

$\begin{array}{cccc}\text { Model 1 } & \text { Model 1a } & \text { Model 1b } & \text { Model 2 } \\ 1.0000 & 0.8365 & 0.9439 & 0.6853 \\ 0.9533 & 1.0000 & 0.7569 & 0.4789 \\ 0.7779 & 0.7683 & 1.0000 & 0.6931 \\ -0.2293 & -0.1734 & -0.0274 & 1.0000\end{array}$


1998

Technical Efficiency

$\begin{array}{lcccc} & \text { Model 1 } & \text { Model 1a } & \text { Model 1b } & \text { Model 2 } \\ \text { Model 1 } & 1.0000 & & & \\ \text { Model 1a } & 0.9068 & 1.0000 & & \\ \text { Model 1b } & 0.4329 & 0.3169 & 1.0000 & 1.0000 \\ \text { Model 2 } & -0.4304 & -0.3372 & -0.5149 & \end{array}$

Pure Technical Efficiency / Scale Efficiency

$\begin{array}{lcccc} & \text { Model 1 } & \text { Model 1a } & \text { Model 1b } & \text { Model 2 } \\ \text { Model 1 } & 1.0000 & 0.8091 & 0.9335 & 0.4423 \\ \text { Model 1a } & 1.0000 & 1.0000 & 0.8114 & 0.3645 \\ \text { Model 1b } & -0.0451 & -0.0443 & 1.0000 & 0.3689 \\ \text { Model 2 } & -0.1361 & -0.1362 & -0.1307 & 1.0000 \\ & & & \\ & & \text { 2001 } & \text { Model 2 } \\ & & \text { Technical Efficiency } & \\ \text { Model 1 } & \text { Model 1a } & \text { Model 1b } & \\ \text { Model 1a } & & & \\ \text { Model 1b } & 1.0000 & 1.0000 & & 1.0000 \\ \text { Model 2 } & 0.8188 & 0.7986 & 1.0000 & 0.4962 \\ \end{array}$

Pure Technical Efficiency / Scale Efficiency

$\begin{array}{lcccc} & \text { Model 1 } & \text { Model 1a } & \text { Model 1b } & \text { Model 2 } \\ \text { Model 1 } & 1.0000 & 0.6133 & 0.9357 & 0.6148 \\ \text { Model 1a } & 0.8926 & 1.0000 & 0.7137 & 0.0263 \\ \text { Model 1b } & 0.8403 & 0.5175 & 1.0000 & 0.3958 \\ \text { Model 2 } & 0.5823 & 0.3790 & 0.6892 & 1.0000\end{array}$

Values in Italics relate to Scale Efficiency. Values in normal text relate to Pure Technical Efficiency or Technical Efficiency as appropriate. Model 1: Inputs: (i) employees, (ii) deposits, (iii) equity capital. Outputs: (i) loans, (ii) off balance sheet items. Model 1a: Inputs: (i) employees, (ii) deposits, (iii) equity capital. Outputs: (i) loans less housing loans, (ii) housing loans (iii) off balance sheet items. Model 1b: Inputs: (i) employees, (ii) deposits, (iii) equity capital. Outputs: (i) loans, (ii) investments, (iii) off balance sheet items.

Model 2 was drawn from the studies of Avkiran (1999 and 2000), and adopts a revenue focus on bank inputs and outputs. This model was found to have low and negative correlations with the other models in the DEA study. Model 2 measures the efficiency of banks in turning costs into revenue, while Model 1 and its variations measure the efficiency of banks turning quantities of inputs into quantities of outputs. The DEA results for Model 2 generally finds the foreign banks to be less efficient than the Big Four and Other Domestic banks. ${ }^{46}$ This is borne out by comparing the DEA results of this study, with those of Avkiran (1999 and 2000), which excluded foreign banks. The average efficiency scores in Model 2 are lower than those found by Avkiran (1999 and 2000) for both the DEA and Malmquist

46 In the case of Model 2, the lower scale efficiency of the Big Four banks does not persist across the entire sample period. The Malmquist Index results demonstrate that this reflects a catching up effect in scale efficiency. 
index studies. However, due to the different sample composition, care should be taken with direct comparisons.

Examination of Models 1, 1a and 1b results in some similar conclusions, in that the Big Four banks generally display lower scale efficiency and higher pure technical efficiency (DEA results), confirming the barriers to entry discussion presented earlier in this paper. Model 1a, with a retail focus, tends to favour the Other Domestic banks, which are also retail focussed. This is consistent with the Berger et al (2000) argument of the home field advantage.

The revenue-focussed model demonstrates the impact of the economic downturn of the early 1990s on the foreign banks. The lower DEA efficiency of the foreign banks, as measured in Model 2, also demonstrates the impact of the barriers to entry to the Australian market caused by the dominant market share of the major banks. Williams (2002) found that the domination of the Australian market by the four major banks resulted in a reduction in foreign bank and foreign merchant bank return on assets. Lozano-Vivas et al (2001) conclude that adverse environmental conditions can act as a barrier to entry to foreign banks. However, the Malmquist results for Model 2 found no substantial differences in efficiency between the three bank types considered in this study.

The differences between Model 1 and its variations and Model 2 for the DEA estimation also indicate that while the foreign banks were more efficient in transforming quantities of inputs into quantities of outputs than domestic banks, this was not reflected in revenue efficiency. This is consistent with the cross-border study of Claessens et al (2001), which found foreign banks are less profitable than domestic banks in developed nations. Claessens et al (2001) argued that foreign bank entry is associated with increased efficiency of the domestic banking system, as reflected in lower profits of domestic banks. ${ }^{47}$ In the case of this study, the DEA results for the revenue-focussed Model 2 also reflects the impact of foreign banks earning lower profits due to barriers to entry presented by the incumbent banks, as well as the economic slowdown of the early 1990s. DeYoung and Nolle (1996) found foreign banks were willing to accept lower profits (hence the lower revenue efficiency found in Model 2) in return for growth, (this higher growth is potentially reflected in the superior efficiency found in Model 1). Williams (2002) found that the barrier to entry resulting from the domination of the Australian market by the Big Four banks resulted in lower foreign bank and foreign merchant bank profits in Australia.

Sathye (2001, p 622) employed a series of subsidiary regressions to determine if the estimated efficiency scores were related to variables such as bank size, foreign ownership and cost per employee. As discussed by Coelli et al (1998, p 171), if the variables used as inputs and outputs are highly correlated with the variables used in the second stage regressions, then any results from second stage regressions are potentially biased. Examination of the correlation between inputs and outputs used in this study with the variables available for a second stage regression revealed high correlations in the order of 0.75 to 0.95 . As a result second stage regressions are inappropriate for this study.

47 It is worth noting that the Malmquist Index results found a reduction in efficiency for the revenue focussed Model 2 for all banks. This could reflect the arguments of Claessens et al (2001). However, sample size constraints prevent a definitive statistical test. 


\section{Conclusions and directions for further research.}

This study has found average Australian bank DEA efficiency is higher than that found by Sathye (2001), but consistent with average efficiency found by Allen and Rai (1996) and Avkiran (1999). In contrast to Allen and Rai (1996), our DEA results show that scale inefficiency dominates technical inefficiency in the Australian case. The explanation for this difference can be found in the behaviour of the Big Four Australian banks during and after deregulation. The major Australian banks used size as a barrier to entry via mergers before the entry of the foreign banks and increased spending upon branch networks (Stearn and Tress, 1983; Hall, 1987; Ferguson, 1990). Williams (2002) finds that this barrier to entry effect resulted in lower foreign bank and foreign merchant bank profits. Lozano-Vivas et al (2001) conclude that negative environmental factors increase the barriers to entry for foreign banks. Our Malmquist Index results show that bank efficiency improved, on average, postderegulation, with the exception of the revenue-focussed Model 2. The main source of efficiency gains post-deregulation was technological change rather than technical efficiency.

Foreign banks in Australia demonstrated superior scale efficiency, which resulted in increased efficiency, on average, compared to the Big Four banks or the Other Domestic Banks. This finding of higher foreign bank efficiency is opposite to that found in other studies surveyed by Berger et al (2000). This is most likely due to the rationing process during deregulation selecting banks possessing attributes consistent with the limited form of the global advantage hypothesis (Berger et al, 2000). An interesting direction for further research would be to determine which foreign bank attributes result in superior efficiency in the host nation. We also suggest that those foreign banks that elected to not convert to branch status, when the opportunity arose, are the most efficient of the foreign banks. The process of conversion to branch status seems to explain the reduction in efficiency changes observed in 1994 for the foreign banks. Again, further research into this issue would be valuable. Some improvement in scale efficiency after the recession of the early 1990s was also found. It is not clear if this scale efficiency improvement is due to the exogenous shock of the recession resulting in increased attention upon scale efficiency, or if this was due to the post-recession consolidation of the banking system.

We conclude that bank efficiency improved post-deregulation, which confirms the results of Avkiran (2000). However, the sample used by Avkiran (2000) excluded foreign banks. Furthermore, those banks with a stronger retail focus were less affected by the losses of the early 1990s in terms of reduced efficiency. Diversity in the types of banks participating in the banking system was found to be an important a source of competitive improvements in efficiency. Consistent with Berger et al (1993), conclusions regarding efficiency were found to be sensitive to the specification of inputs and outputs. In many cases the choice of inputs and outputs is driven by data availability considerations. However, this study indicates that foreign banks were more efficient than domestic banks, on average, postderegulation, but this higher efficiency was not found to imply higher foreign bank profits.

\section{Bibliography.}

Ackland, R and I. Harper, 1992, Financial deregulation in Australia: boon or bane?, in: P. Forsyth, ed., Microeconomic reform in Australia, Allen and Unwin, Sydney, Chapter 3, 45 - 71. 
Allen, L and A. Rai, 1996, Operational efficiency in banking: an international comparison, Journal of Banking and Finance 20, 655 - 672.

Avkiran, N., 1999, The evidence on efficiency gains: the role of mergers and the benefits to the public, Journal of Banking and Finance 23, 991 - 1013.

Avkiran N., 2000, Rising productivity of Australian trading banks under deregulation 1986-1995, Journal of Economics and Finance V24, 122 -140.

Australian Financial System Inquiry, 1981, Final Report, Australian Government Publishing Service, Canberra.

Berg, S., F. Førsund and E. Jansen, 1992, Malmquist indices of productivity growth during the deregulation of Norwegian banking, 1980 - 89, Scandinavian Journal of Economics 94, Supplement, $211-228$.

Berger, A., R. Demsetz and D. Strahan, 1999, The consolidation of the financial services industry: causes, consequences and implications for the future, Journal of Banking and Finance 23, 135 - 194.

Berger, A., R. DeYoung, H. Genay and G. Udell, 2000, Globalisation of financial institutions: evidence from cross-border banking performance, Brookings-Wharton Papers on Financial Service 3, $23-120$.

Berger, A. and D. Humphrey, 1992, Measurement and efficiency issues in commercial banking, in: Z. Griliches, ed., Output measurement in the service sector, 245 - 275. The University of Chicago Press, Chicago.

Berger, A. and D. Humphrey, 1997, Efficiency of financial institutions: international survey and directions for further research, European Journal of Operational Research 98, 175 - 212.

Berger, A., W. Hunter and S. Timme, 1993, The efficiency of financial institutions: a review and preview of research past present and future, Journal of Banking and Finance 17, 221 - 249.

Berger, A. and L. Mester, 1997, Inside the black box: what explains differences in the efficiencies of financial institutions?, Journal of Banking and Finance 21, 895 - 947.

Bhattacharyya, A., C. Lovell and P. Sahay, 1997, The impact of liberalisation on the productive efficiency of Indian commercial banks, European Journal of Operational Research 98, 332 - 343.

Carew, E., 1998, Fast money 4, Allen and Unwin, Sydney.

Chang, C., I. Hasan and W. Hunter, 1998, Efficiency of multinational banks: an empirical investigation, Applied Financial Economics 8, 689 - 696.

Claessens, S., A. Demirgüc-Kunt and H. Huizinga, 2001, How does foreign bank entry affect domestic banking markets?, Journal of Banking and Finance 25, 891 - 911.

Coelli, T., P. Rao and G. Battese, 1998, An introduction to efficiency and productivity analysis, Kluwer, Boston

Davis, K. and M. Lewis, 1982, Foreign banks and the financial system, Australian financial system inquiry, Commissioned studies and selected papers, Part 1, Australian Government Publishing Service, Canberra.

Demigüc-Kunt, A., and H. Huizinga, 2001, The taxation of domestic and foreign banking, Journal of Public Economics, 79, 429 - 453.

DeYoung, R., and D. Nolle, 1996, Foreign-owned banks in the United States: earning market share or buying it?, Journal of Money Credit and Banking 28, 622 - 636.

East, D., 1993, Foreign banks in Australia, The Australian Banker, August 1993, 208 - 209.

Färe, R., S. Grosskopf, M. Norris and Z. Zhang, 1994, Productivity growth, technical progress and efficiency change in industrialised countries, American Economic Review, 84, 66 - 83 
Favero, C. and L. Papi, 1995, Technical efficiency and scale efficiency in the Italian banking sector: a non-parametric approach, Applied Economics 27, 385 - 395.

Ferguson, R., 1990, Foreign banks in Australia: a strategic reassessment, Economic Papers 9, 1 - 8.

Financial System Inquiry, 1997, Financial System Inquiry Final Report, (Chairman S. Wallis), Australian Government Printing Service, Canberra.

Gilbert, R. and P. Wilson, 1998, Effects of deregulation on the productivity of Korean banks, Journal of Economics and Business 50, 133 - 155.

Grifell-Tatje, E. and C. Lovell, 1996, Deregulation and productivity decline: the case of Spanish savings banks, European Economic Review 40, 1281 - 1303.

Hall, M., 1987, Financial deregulation: a comparative study of Australia and the United Kingdom, MacMillan Press, London.

Harper, I.R., 1986, Why financial deregulation?, Australian Economic Review 1, 37 - 49.

Hasan, I. and W. Hunter, 1996, Efficiency of Japanese multinational Banks in the United States, Research in Finance 14, 157 - 173.

Hogan, W., 1991, New banks: impact and response, Economic Papers 10, 11 - 33.

Leightner, J. and C. Lovell, 1998, The impact of financial liberalisation on the performance of Thai banks, Journal of Economics and Business 50, 115 - 131.

Lewis, M. and R. Wallace, 1997, The Australian financial system, Longman, South Melbourne.

Lozano-Vivas, A., J. Pastor and I. Hasan, 2001, European bank performance beyond country borders: What really matters? European Finance Review, 5, 141 - 165.

Mahajan, A., N. Rangan and A. Zardkoohi, 1996, Cost structures in multinational and domestic banking, Journal of Banking and Finance 20, 283 - 306.

Metcalfe, B., 1985, Foreign banks in Australia, 1985, Price Waterhouse and Company, Sydney.

Milbourne, R. Cumberworth, M., 1991, Australian banking performance in an era of deregulation. Australian Economic Papers, 30, 171 - 191.

Miller, S. and Parkhe, A., 2002, Is there a liability of foreignness in global banking? An empirical test of banks' x-efficiency, Strategic Management Journal, 23, 55 - 76.

Mukherjee, K., S. Ray and S Miller, 2001, Productivity growth in large US commercial banks: the initial post-deregulation experience, Journal of Banking and Finance 25, 913 - 939.

Noulas, A., 1997, Productivity growth in the Hellenic banking industry: state versus private banks, Applied Financial Economics 7, 223 - 228.

Oster, A., and L. Antioch, 1995, Measuring productivity in the Australian banking sector, in: P. Andersen, J. Dwyer, D. Gruen, eds., Productivity and Growth, proceedings of a conference, Reserve Bank of Australia, July 1995.

Pauly, L., 1987, Foreign banks in Australia: the politics of deregulation, Australian Professional Publications.

Perkins, J.O.N., 1989, The deregulation of the Australian financial system: the experience of the 1980s, Melbourne University Press, Melbourne.

Reserve Bank of Australia, 1994, Foreign banks in Australia, Reserve Bank of Australia Bulletin September, $16-22$.

Revell, J., 1980, Costs and margins in banking: an international survey, Organisation for Economic Co-operation and Development, Paris. 
Sathye, M., 2001, X-efficiency of Australian banking: an empirical investigation, Journal of Banking and Finance 25, $613-630$.

Sathye, M., 2002, Measuring productivity changes in Australian banking: An application of Malmquist indices, Managerial Finance, 28, 48 - 59.

Shyu, J., 1998, Deregulation and bank operating efficiency: an empirical study of Taiwan's banks, Journal of Emerging Markets 3, 27 - 46.

Singh, S., 1991, The bankers, Allen and Unwin Publishing, Sydney.

Stearn, G. and R. Tress, 1983, Australian bank mergers of 1981: their motivation and effects, Bulletin of Money, Banking and Finance 2, 29 - 55.

Swan P. and I. Harper, 1982, The welfare gains from bank deregulation, Australian Financial System Inquiry, Commissioned studies and selected papers, Part 1, 475 - 512. Australian Government Publishing Service, Canberra.

Standing Committee on Finance and Public Administration [SCOFPA], 1991, A pocket full of change: banking and deregulation, House of Representatives, Commonwealth Parliament, Australian Government Publishing Service, Canberra.

Sykes, T., 1996, The bold riders, Allen and Unwin Publishing, Sydney.

Walker, G., 1998, Economies of scale in Australian banks, 1978 - 1990, Australian Economic Papers $37,71-87$.

Williams, B., 2002, Domestic and international determinants of bank profits: Foreign banks in Australia, Journal of Banking and Finance, forthcoming.

Worthington, A., 1999, Malmquist indices of productivity change in Australian financial services, Journal of International Financial Markets, Institutions and Money, 9, 303 - 320.

Zaheer, S., 1995, Overcoming the liability of foreignness, Academy of Management Journal, 38, 341 363.

Zaheer, S., and E. Mosakowski, 1997, The dynamics of the liability of foreignness: A global study of survival in financial services, Strategic Management Journal, 18, 439 - 464.

Zaim, O., 1995, The effect of financial liberalisation on the efficiency of Turkish commercial banks, Applied Financial Economics 5, 257 - 264. 


\section{Appendix}

Table A1

Sample Characteristics of Model 1a: DEA

\begin{tabular}{|r|r|r|r|r|}
\hline Year & Big 4 & Other Domestic & Foreign & Total \\
\hline 1988 & 2 & 1 & 3 & 6 \\
\hline 1989 & 3 & 3 & 12 & 18 \\
\hline 1990 & 3 & 7 & 13 & 23 \\
\hline 1991 & 4 & 9 & 13 & 26 \\
\hline 1992 & 4 & 9 & 12 & 25 \\
\hline 1993 & 4 & 9 & 11 & 24 \\
\hline 1994 & 4 & 10 & 11 & 25 \\
\hline 1995 & 4 & 10 & 9 & 23 \\
\hline 1996 & 4 & 10 & 6 & 20 \\
\hline 1997 & 4 & 7 & 6 & 17 \\
\hline 1998 & 4 & 5 & 4 & 13 \\
\hline 1999 & 4 & 5 & 4 & 13 \\
\hline 2000 & 4 & 4 & 2 & 10 \\
\hline 2001 & 4 & 5 & 1 & 10 \\
\hline
\end{tabular}

Model 1a: Inputs: (i) employees, (ii) deposits, (iii) equity capital. Outputs: (i) loans less housing loans, (ii) housing loans (iii) off balance sheet items.

Table A2

Sample Characteristics of Model 1b: DEA

\begin{tabular}{|c|c|c|c|c|}
\hline Year & Big 4 & Other Domestic & Foreign & Total \\
\hline 1988 & 2 & 3 & 13 & 18 \\
\hline 1989 & 3 & 8 & 15 & 26 \\
\hline 1990 & 3 & 7 & 13 & 23 \\
\hline 1991 & 4 & 9 & 13 & 26 \\
\hline 1992 & 4 & 9 & 12 & 25 \\
\hline 1993 & 4 & 9 & 11 & 24 \\
\hline 1994 & 4 & 10 & 11 & 25 \\
\hline 1995 & 4 & 10 & 9 & 23 \\
\hline 1996 & 4 & 10 & 6 & 20 \\
\hline 1997 & 4 & 7 & 6 & 17 \\
\hline 1998 & 4 & 5 & 4 & 13 \\
\hline 1999 & 4 & 5 & 4 & 13 \\
\hline 2000 & 4 & 4 & 2 & 10 \\
\hline 2001 & 4 & 5 & 1 & 10 \\
\hline
\end{tabular}

Model 1b Inputs: (i) employees, (ii) deposits, (iii) equity capital. Outputs: (i) loans, (ii) investments, (iii) off balance sheet items.

Table A3

Sample Characteristics of Model 2: DEA

\begin{tabular}{|r|r|r|r|r|}
\hline Year & Big 4 & Other Domestic & Foreign & Total \\
\hline 1988 & 4 & 8 & 7 & 19 \\
\hline 1989 & 4 & 9 & 8 & 21 \\
\hline 1990 & 4 & 9 & 7 & 20 \\
\hline 1991 & 4 & 10 & 7 & 21 \\
\hline 1992 & 4 & 10 & 7 & 21 \\
\hline 1993 & 4 & 12 & 7 & 23 \\
\hline 1994 & 4 & 10 & 7 & 21 \\
\hline 1995 & 4 & 11 & 5 & 20 \\
\hline
\end{tabular}




\begin{tabular}{|r|r|r|r|r|}
\hline 1996 & 4 & 11 & 5 & 20 \\
\hline 1997 & 4 & 8 & 4 & 16 \\
\hline 1998 & 4 & 9 & 5 & 18 \\
\hline 1999 & 4 & 7 & 5 & 16 \\
\hline 2000 & 4 & 8 & 4 & 16 \\
\hline 2001 & 4 & 8 & 1 & 13 \\
\hline
\end{tabular}

Model 2: Inputs: (i) interest expenses, (ii) non-interest expenses. Outputs: (i) net interest income, (ii) noninterest income.

Table A4

Average DEA Efficiency Scores: Model 1a.

(Standard Deviations in Parentheses)

\begin{tabular}{|c|c|c|c|}
\hline Year & & & \\
\hline 1988 & TE & PTE & Scale \\
\hline All & $\begin{array}{r}0.96^{*} \\
(0.08)\end{array}$ & $\begin{array}{r}1.00 * \\
(0.00)\end{array}$ & $\begin{array}{r}0.96^{*} \\
(0.08)\end{array}$ \\
\hline Big 4 & $\begin{array}{r}0.87 \\
(0.10) \\
\end{array}$ & $\begin{array}{l}1.00 * \\
(0.00)\end{array}$ & $\begin{array}{r}0.87 \\
(0.10) \\
\end{array}$ \\
\hline ODOM & $\begin{array}{l}\mathbf{1 . 0 0}^{*} \\
(0.00)\end{array}$ & $\begin{array}{l}1.00 * \\
(0.00)\end{array}$ & $\begin{array}{l}1.00^{*} \\
(0.00)\end{array}$ \\
\hline Foreign & $\begin{array}{l}\mathbf{1 . 0 0}^{*} \\
(0.00)\end{array}$ & $\begin{array}{l}1.00 * \\
(0.00)\end{array}$ & $\begin{array}{l}1.00^{*} \\
(0.00)\end{array}$ \\
\hline 1990 & TE & PTE & Scale \\
\hline All & $\begin{array}{r}0.83^{*} \\
0.22\end{array}$ & $\begin{array}{r}0.93^{*} \\
0.18\end{array}$ & $\begin{array}{r}0.98^{*} \\
0.19\end{array}$ \\
\hline Big 4 & $\begin{array}{l}0.69 \\
0.14\end{array}$ & $\begin{array}{r}\mathbf{0 . 9 9} * \\
0.02\end{array}$ & $\begin{array}{l}0.70 \\
0.14\end{array}$ \\
\hline ODOM & $\begin{array}{r}\mathbf{0 . 8 9}^{*} \\
0.20\end{array}$ & $\begin{array}{r}0.93^{*} \\
0.18\end{array}$ & $\begin{array}{r}0.98 * \\
0.09\end{array}$ \\
\hline Foreign & $\begin{array}{r}0.82^{*} \\
0.24\end{array}$ & $\begin{array}{r}0.92 * \\
0.21\end{array}$ & $\begin{array}{r}\mathbf{1 . 0 4} * \\
0.18\end{array}$ \\
\hline
\end{tabular}

\begin{tabular}{|l|r|r|r|}
\hline 1992 & \multicolumn{1}{|l|}{ TE } & \multicolumn{1}{l|}{ PTE } & \multicolumn{1}{l|}{ Scale } \\
\hline All & $0.87^{*}$ & $0.94^{*}$ & $1.00^{*}$ \\
& $(0.19)$ & $(0.16)$ & $(0.13)$ \\
\hline Big 4 & $\mathbf{0 . 9 4}^{*}$ & $\mathbf{1 . 0 0}^{*}$ & $0.94^{*}$ \\
& $(0.10)$ & $(0.00)$ & $(0.10)$ \\
\hline ODOM & $0.89^{*}$ & $0.96^{*}$ & $0.97^{*}$ \\
& $(0.19)$ & $(0.12)$ & $(0.16)$ \\
\hline Foreign & $0.84^{*}$ & $0.90^{*}$ & $\mathbf{1 . 0 4}^{*}$ \\
& $(0.21)$ & $(0.20)$ & $(0.11)$ \\
\hline
\end{tabular}

\begin{tabular}{|l|r|r|r|}
\hline 1994 & \multicolumn{1}{|l|}{ TE } & \multicolumn{1}{l|}{ PTE } & \multicolumn{1}{l|}{ Scale } \\
\hline All & $0.84^{*}$ & $0.95^{*}$ & $0.90^{*}$ \\
& $(0.21)$ & $(0.14)$ & $(0.19)$ \\
\hline Big 4 & 0.79 & $\mathbf{1 . 0 0}^{*}$ & 0.79 \\
& $(0.03)$ & $(0.00)$ & $(0.03)$ \\
\hline ODOM & $\mathbf{0 . 9 1}^{*}$ & $0.97^{*}$ & $\mathbf{0 . 9 6}$ \\
& $(0.12)$ & $(0.06)$ & $(0.10)$ \\
\hline Foreign & $0.79^{*}$ & $0.93^{*}$ & $0.89^{*}$ \\
& $(0.29)$ & $(0.20)$ & $(0.26)$ \\
\hline
\end{tabular}

\begin{tabular}{|l|r|r|r|}
\hline 1996 & \multicolumn{1}{|l|}{ TE } & \multicolumn{1}{l|}{ PTE } & \multicolumn{1}{l|}{ Scale } \\
\hline All & $0.91^{*}$ & $0.99^{*}$ & $0.98^{*}$ \\
& $(0.10)$ & $(0.03)$ & $(0.12)$ \\
\hline Big 4 & $0.91^{*}$ & $\mathbf{1 . 0 0}^{*}$ & $0.91^{*}$ \\
& $(0.11)$ & $(0.00)$ & $(0.11)$ \\
\hline ODOM & $0.89^{*}$ & $0.97^{*}$ & $0.98^{*}$ \\
& $(0.09)$ & $(0.04)$ & $(0.11)$ \\
\hline Foreign & $\mathbf{0 . 9 3}^{*}$ & $\mathbf{1 . 0 0}^{*}$ & $\mathbf{1 . 0 1}^{*}$ \\
& $(0.12)$ & $(0.00)$ & $(0.14)$ \\
\hline
\end{tabular}

\begin{tabular}{|l|r|r|r|}
\hline Year & & & \\
\hline 1989 & \multicolumn{1}{|l|}{ TE } & \multicolumn{1}{|c|}{ PTE } & \multicolumn{1}{l|}{ Scale } \\
\hline All & $0.77^{*}$ & $0.92^{*}$ & $0.94^{*}$ \\
& $(0.23)$ & $(0.18)$ & $(0.23)$ \\
\hline Big 4 & 0.66 & $\mathbf{0 . 9 9} *$ & 0.67 \\
& $(0.07)$ & $(0.02)$ & $(0.07)$ \\
\hline ODOM & $0.74^{*}$ & $0.84^{*}$ & $\mathbf{1 . 0 5}^{*}$ \\
& $(0.33)$ & $(0.27)$ & $(0.23)$ \\
\hline Foreign & $\mathbf{0 . 8 0}^{*}$ & $0.92^{*}$ & $0.98^{*}$ \\
& $(0.24)$ & $(0.18)$ & $(0.21)$ \\
\hline
\end{tabular}

\begin{tabular}{|l|r|r|r|}
\hline 1991 & \multicolumn{1}{l|}{ TE } & \multicolumn{1}{l|}{ PTE } & \multicolumn{1}{l|}{ Scale } \\
\hline All & $0.79^{*}$ & $0.90^{*}$ & $0.95^{*}$ \\
& $(0.21)$ & $(0.20)$ & $(0.18)$ \\
\hline Big 4 & 0.74 & $\mathbf{0 . 9 8}^{*}$ & 0.76 \\
& $(0.09)$ & $(0.04)$ & $(0.08)$ \\
\hline ODOM & $0.79^{*}$ & $0.90^{*}$ & $0.89^{*}$ \\
& $(0.20)$ & $(0.18)$ & $(0.16)$ \\
\hline Foreign & $0.81^{*}$ & $0.88^{*}$ & $\mathbf{1 . 0 6}^{*}$ \\
& $(0.25)$ & $(0.24)$ & $(0.14)$ \\
\hline
\end{tabular}

\begin{tabular}{|l|r|r|r|}
\hline 1993 & \multicolumn{1}{|l|}{ TE } & \multicolumn{1}{l|}{ PTE } & \multicolumn{1}{l|}{ Scale } \\
\hline All & $0.86^{*}$ & $0.92^{*}$ & $0.97^{*}$ \\
& $(0.18)$ & $(0.17)$ & $(0.12)$ \\
\hline Big 4 & $\mathbf{0 . 8 9}$ & $\mathbf{1 . 0 0}^{*}$ & 0.89 \\
& $(0.06)$ & $(0.00)$ & $(0.06)$ \\
\hline ODOM & $0.85^{*}$ & $0.95^{*}$ & $0.93^{*}$ \\
& $(0.16)$ & $(0.11)$ & $(0.17)$ \\
\hline Foreign & $0.85^{*}$ & $0.87^{*}$ & $\mathbf{1 . 0 3}^{*}$ \\
& $(0.23)$ & $(0.22)$ & $(0.06)$ \\
\hline
\end{tabular}

\begin{tabular}{|l|r|r|r|}
\hline 1995 & \multicolumn{1}{|l|}{ TE } & \multicolumn{1}{l|}{ PTE } & \multicolumn{1}{l|}{ Scale } \\
\hline All & $0.85^{*}$ & $0.96^{*}$ & $0.93^{*}$ \\
& $(0.20)$ & $(0.08)$ & $(0.21)$ \\
\hline Big 4 & $\mathbf{0 . 9 2}^{*}$ & $\mathbf{1 . 0 0}^{*}$ & $0.92^{*}$ \\
& $(0.08)$ & $(0.00)$ & $(0.08)$ \\
\hline ODOM & $0.87^{*}$ & $0.92^{*}$ & $\mathbf{0 . 9 9}$ \\
& $(0.11)$ & $(0.10)$ & $(0.07)$ \\
\hline Foreign & $0.80^{*}$ & $0.98^{*}$ & $0.88^{*}$ \\
& $(0.31)$ & $(0.06)$ & $(0.33)$ \\
\hline
\end{tabular}

\begin{tabular}{|l|r|r|r|}
\hline \multicolumn{1}{l|}{ 1997 } & \multicolumn{1}{|l|}{ TE } & \multicolumn{1}{l|}{ PTE } & \multicolumn{1}{l|}{ Scale } \\
\hline All & $0.84^{*}$ & $0.96^{*}$ & $0.92^{*}$ \\
& $(0.16)$ & $(0.11)$ & $(0.16)$ \\
\hline Big 4 & $0.82^{*}$ & $\mathbf{1 . 0 0}^{*}$ & $0.82^{*}$ \\
& $(0.13)$ & $(0.00)$ & $(0.13)$ \\
\hline ODOM & $\mathbf{0 . 8 5}^{*}$ & $0.97^{*}$ & $\mathbf{0 . 9 8}^{*}$ \\
& $(0.11)$ & $(0.07)$ & $(0.16)$ \\
\hline Foreign & $0.84^{*}$ & $0.93^{*}$ & $0.91^{*}$ \\
& $(0.24)$ & $(0.16)$ & $(0.16)$ \\
\hline
\end{tabular}




\begin{tabular}{|l|r|r|r|}
\hline 1998 & \multicolumn{1}{l|}{ TE } & \multicolumn{1}{l|}{ PTE } & \multicolumn{1}{l|}{ Scale } \\
\hline All & $0.92^{*}$ & $0.97^{*}$ & $0.98^{*}$ \\
& $(0.11)$ & $(0.09)$ & $(0.08)$ \\
\hline Big 4 & $0.90^{*}$ & $\mathbf{1 . 0 0}^{*}$ & $0.90^{*}$ \\
& $(0.08)$ & $(0.00)$ & $(0.08)$ \\
\hline ODOM & $0.91^{*}$ & $0.93^{*}$ & $1.01^{*}$ \\
& $(0.15)$ & $(0.15)$ & $(0.04)$ \\
\hline Foreign & $\mathbf{0 . 9 6}^{*}$ & $\mathbf{1 . 0 0}^{*}$ & $\mathbf{1 . 0 3}^{*}$ \\
& $(0.07)$ & $(0.01)$ & $(0.07)$ \\
\hline
\end{tabular}

\begin{tabular}{|l|r|r|r|}
\hline 1999 & \multicolumn{1}{|l|}{ TE } & \multicolumn{1}{l|}{ PTE } & \multicolumn{1}{l|}{ Scale } \\
\hline All & $0.92^{*}$ & $0.97^{*}$ & $1.00^{*}$ \\
& $(0.10)$ & $(0.09)$ & $(0.09)$ \\
\hline Big 4 & $\mathbf{0 . 9 4}^{*}$ & $\mathbf{1 . 0 0}^{*}$ & $0.94^{*}$ \\
& $(0.08)$ & $(0.00)$ & $(0.08)$ \\
\hline ODOM & $0.89^{*}$ & $0.91^{*}$ & $1.01^{*}$ \\
& $(0.12)$ & $90.13)$ & $(0.04)$ \\
\hline Foreign & $\mathbf{0 . 9 4}^{*}$ & $\mathbf{1 . 0 0}^{*}$ & $\mathbf{1 . 0 6}^{*}$ \\
& $(0.12)$ & $(0.00)$ & $(0.12)$ \\
\hline
\end{tabular}

\begin{tabular}{|l|r|r|r|}
\hline 2000 & \multicolumn{1}{|l|}{ TE } & \multicolumn{1}{l|}{ PTE } & \multicolumn{1}{l|}{ Scale } \\
\hline All & $0.96^{*}$ & $1.00^{*}$ & $0.96^{*}$ \\
& $(0.07)$ & $(0.01)$ & $(0.06)$ \\
\hline Big 4 & $0.94^{*}$ & $\mathbf{1 . 0 0}^{*}$ & $0.94^{*}$ \\
& $(0.07)$ & $90.00)$ & $90.07)$ \\
\hline ODOM & $0.96^{*}$ & $0.99^{*}$ & $0.97^{*}$ \\
& $(0.08)$ & $(0.02)$ & $(0.07)$ \\
\hline Foreign & $\mathbf{1 . 0 0}^{*}$ & $\mathbf{1 . 0 0}^{*}$ & $\mathbf{1 . 0 0}^{*}$ \\
& $(0.00)$ & $(0.00)$ & $(0.00)$ \\
\hline
\end{tabular}

\begin{tabular}{|l|r|r|r|}
\hline 2001 & \multicolumn{1}{l|}{ TE } & \multicolumn{1}{l|}{ PTE } & \multicolumn{1}{l|}{ Scale } \\
\hline All & $0.97^{*}$ & $0.99^{*}$ & $1.00^{*}$ \\
& $(0.05)$ & $(0.03)$ & $(0.05)$ \\
\hline Big 4 & $0.97^{*}$ & $\mathbf{1 . 0 0}^{*}$ & $0.97^{*}$ \\
& $(0.05)$ & $(0.00)$ & $(0.05)$ \\
\hline ODOM & $0.96^{*}$ & $0.98^{*}$ & $\mathbf{1 . 0 2}^{*}$ \\
& $(0.06)$ & $(0.03)$ & $(0.04)$ \\
\hline Foreign & $\mathbf{1 . 0 0}^{*}$ & $\mathbf{1 . 0 0}^{*}$ & $1.00^{*}$ \\
& $(0.00)$ & $(0.00)$ & $(0.00)$ \\
\hline
\end{tabular}

Model 1a: Inputs: (i) employees, (ii) deposits, (iii) equity capital. Outputs: (i) loans less housing loans, (ii) housing loans (iii) off balance sheet items.

TE: Technical Efficiency, PTE: Pure Technical Efficiency, Scale: Scale Efficiency. ODOM: Other Domestic. Values in bold are the largest for that category in that year. * Indicates maximum value of 1 for that category.

Scale Efficiency is calculated as decreasing return to scale; scale efficiency score unchanged; constant returns to scale score unchanged; increasing returns to scale, score transformed to (2- original score). Thus, an average scale efficiency score above 1 indicates increasing returns to scale on average, below one indicates decreasing returns to scale on average and a score of one indicates constant returns to scale on average.

Table A5

Average DEA Efficiency Scores: Model 1b.

(Standard Deviations in Parentheses)

\begin{tabular}{|c|c|c|c|}
\hline Year & & & \\
\hline 1988 & TE & PTE & Scale \\
\hline All & $0.83^{*}$ & 0.94* & 0.94* \\
\hline Big 4 & $\begin{array}{r}0.63 \\
(0.12)\end{array}$ & $\begin{array}{l}\text { 1.00* } \\
(0.00)\end{array}$ & $\begin{array}{r}0.63 \\
(0.12)\end{array}$ \\
\hline ODOM & $\begin{array}{l}0.82^{*} \\
(0.32)\end{array}$ & $\begin{array}{l}0.91^{*} \\
(0.15)\end{array}$ & $\begin{array}{l}\text { 1.13* }^{*} \\
(0.23)\end{array}$ \\
\hline Foreign & $\begin{array}{c}\mathbf{0 . 8 6}^{*} \\
(0.19)\end{array}$ & $\begin{array}{l}0.94^{*} \\
(0.12)\end{array}$ & $\begin{array}{l}0.95^{*} \\
(0.17)\end{array}$ \\
\hline 1990 & TE & $\begin{array}{l}\text { PTE } \\
\end{array}$ & Scale \\
\hline All & $\begin{array}{c}0.85^{*} \\
(0.16)\end{array}$ & $\begin{array}{c}0.94 * \\
(0.13)\end{array}$ & $\begin{array}{c}0.93^{*} \\
(0.15)\end{array}$ \\
\hline Big 4 & $\begin{array}{r}0.67 \\
(0.11)\end{array}$ & $\begin{array}{l}\text { 1.00* } \\
(0.00)\end{array}$ & $\begin{array}{r}0.67 \\
(0.11)\end{array}$ \\
\hline ODOM & $\begin{array}{l}0.75^{*} \\
(0.15)\end{array}$ & $\begin{array}{l}0.82^{*} \\
(0.18)\end{array}$ & $\begin{array}{l}0.94^{*} \\
(0.12)\end{array}$ \\
\hline Foreign & $\begin{array}{l}\mathbf{0 . 9 4}^{*} \\
(0.11)\end{array}$ & $\begin{array}{l}0.99^{*} \\
(0.03)\end{array}$ & $\begin{array}{l}\mathbf{0 . 9 9 *} \\
(0.11)\end{array}$ \\
\hline
\end{tabular}

\begin{tabular}{|l|r|r|r|}
\hline Year & & \multicolumn{1}{|c|}{} & \\
\hline 1989 & \multicolumn{1}{|l|}{ TE } & \multicolumn{1}{|c|}{ PTE } & Scale \\
\hline All & $0.87^{*}$ & $0.97^{*}$ & $0.95^{*}$ \\
& 0.14 & 0.08 & 0.15 \\
\hline Big 4 & 0.68 & $\mathbf{1 . 0 0}^{*}$ & 0.68 \\
& 0.07 & 0.00 & 0.07 \\
\hline ODOM & $0.82^{*}$ & $0.92^{*}$ & $\mathbf{0 . 9 8}^{*}$ \\
& 0.16 & 0.13 & 0.14 \\
\hline Foreign & $\mathbf{0 . 9 3}^{*}$ & $0.99^{*}$ & $\mathbf{0 . 9 8}^{*}$ \\
& 0.10 & 0.03 & 0.10 \\
\hline
\end{tabular}

\begin{tabular}{|l|r|r|r|}
\hline 1991 & \multicolumn{1}{|l|}{ TE } & \multicolumn{1}{l|}{ PTE } & \multicolumn{1}{l|}{ Scale } \\
\hline All & $0.76^{*}$ & $0.89^{*}$ & $0.92^{*}$ \\
& 0.19 & 0.18 & 0.19 \\
\hline Big 4 & 0.72 & $\mathbf{0 . 9 7}^{*}$ & 0.75 \\
& 0.10 & 0.07 & 0.07 \\
\hline ODOM & $0.68^{*}$ & $0.80^{*}$ & $0.88^{*}$ \\
& 0.20 & 0.23 & 0.18 \\
\hline Foreign & $\mathbf{0 . 8 3}^{*}$ & $0.94^{*}$ & $\mathbf{1 . 0 0}$ \\
& 0.19 & 0.14 & 0.19 \\
\hline
\end{tabular}

\begin{tabular}{|l|r|r|r|}
\hline 1992 & \multicolumn{1}{|l|}{ TE } & \multicolumn{1}{l|}{ PTE } & \multicolumn{1}{l|}{ Scale } \\
\hline All & $0.84^{*}$ & $0.94^{*}$ & $0.94^{*}$ \\
& 0.17 & 0.11 & 0.16 \\
\hline Big 4 & 0.81 & $\mathbf{1 . 0 0}^{*}$ & 0.81 \\
& 0.15 & 0.00 & 0.15 \\
\hline ODOM & $0.75^{*}$ & $0.89^{*}$ & $0.89^{*}$ \\
& 0.19 & 0.13 & 0.20 \\
\hline Foreign & $\mathbf{0 . 9 1 *}$ & $0.96^{*}$ & $\mathbf{1 . 0 1}^{*}$ \\
& 0.13 & 0.10 & 0.10 \\
\hline
\end{tabular}

\begin{tabular}{|l|r|r|r|}
\hline 1993 & \multicolumn{1}{|l|}{ TE } & \multicolumn{1}{l|}{ PTE } & \multicolumn{1}{l|}{ Scale } \\
\hline All & $0.82^{*}$ & $0.94^{*}$ & $0.91^{*}$ \\
& $(0.18)$ & $(0.14)$ & $(0.16)$ \\
\hline Big 4 & 0.72 & $\mathbf{0 . 9 8}^{*}$ & 0.73 \\
& $(0.08)$ & $(0.05)$ & $(0.06)$ \\
\hline ODOM & $0.81^{*}$ & $0.94^{*}$ & $0.90^{*}$ \\
& $(0.17)$ & $(0.12)$ & $(0.17)$ \\
\hline Foreign & $\mathbf{0 . 8 6}^{*}$ & $0.92^{*}$ & $\mathbf{0 . 9 8}^{*}$ \\
& $(0.20)$ & $(0.17)$ & $(0.13)$ \\
\hline
\end{tabular}

\begin{tabular}{|l|l|l|l|}
\hline 1994 & TE & PTE & Scale \\
\hline
\end{tabular}

\begin{tabular}{|l|l|l|l|}
\hline 1995 & TE & PTE & Scale \\
\hline
\end{tabular}




\begin{tabular}{|l|r|r|r|}
\hline All & $0.86^{*}$ & $0.96^{*}$ & $0.93^{*}$ \\
& $(0.15)$ & $(0.10)$ & $(0.15($ \\
\hline Big 4 & 0.71 & $\mathbf{1 . 0 0}^{*}$ & 0.71 \\
& $(0.07)$ & $(0.00)$ & $(0.07)$ \\
\hline ODOM & $0.87^{*}$ & $0.95^{*}$ & $0.94^{*}$ \\
& $(0.11)$ & $(0.09)$ & $(0.11)$ \\
\hline Foreign & $\mathbf{0 . 9 0}^{*}$ & $0.95^{*}$ & $\mathbf{0 . 9 9 *}$ \\
& $(0.18)$ & $(0.13)$ & $(0.14)$ \\
\hline
\end{tabular}

\begin{tabular}{|l|c|c|c|}
\hline All & $0.86^{*}$ & $0.96^{*}$ & $0.93^{*}$ \\
& $(0.13)$ & $(0.08)$ & $(0.13)$ \\
\hline Big 4 & $0.82^{*}$ & $\mathbf{1 . 0 0}^{*}$ & $0.82^{*}$ \\
& $(0.12)$ & $(0.00)$ & $(0.12)$ \\
\hline ODOM & $0.82^{*}$ & $0.93^{*}$ & $0.90^{*}$ \\
& $(0.11)$ & $(0.10)$ & $(0.11)$ \\
\hline Foreign & $\mathbf{0 . 9 3}^{*}$ & $0.98^{*}$ & $\mathbf{1 . 0 0}^{*}$ \\
& $(0.13)$ & $(0.06)$ & $(0.11)$ \\
\hline
\end{tabular}

\begin{tabular}{|l|r|r|r|}
\hline 1996 & \multicolumn{1}{|l|}{ TE } & \multicolumn{1}{l|}{ PTE } & \multicolumn{1}{l|}{ Scale } \\
\hline All & $0.87^{*}$ & $0.98^{*}$ & $0.96^{*}$ \\
& $(0.12)$ & $(0.05)$ & $(0.16)$ \\
\hline Big 4 & 0.78 & $0.99^{*}$ & 0.78 \\
& $(0.14)$ & $(0.01)$ & $(0.14)$ \\
\hline ODOM & $0.86^{*}$ & $0.97^{*}$ & $0.98^{*}$ \\
& $(0.10)$ & $(0.08)$ & $(0.15)$ \\
\hline Foreign & $\mathbf{0 . 9 6}^{*}$ & $\mathbf{1 . 0 0}^{*}$ & $\mathbf{1 . 0 4}^{*}$ \\
& $(0.11)$ & $(0.00)$ & $(0.11)$ \\
\hline
\end{tabular}

\begin{tabular}{|l|r|r|r|}
\hline 1997 & \multicolumn{1}{|l|}{ TE } & \multicolumn{1}{l|}{ PTE } & \multicolumn{1}{l|}{ Scale } \\
\hline All & $0.88^{*}$ & $0.98^{*}$ & $0.93^{*}$ \\
& $(0.15)$ & $(0.05)$ & $(0.16)$ \\
\hline Big 4 & $0.85^{*}$ & $\mathbf{1 . 0 0}^{*}$ & $0.85^{*}$ \\
& $(0.12)$ & $(0.00)$ & $(0.12)$ \\
\hline ODOM & 0.88 & $0.98^{*}$ & $\mathbf{0 . 9 8}$ \\
& $(0.10)$ & $(0.04)$ & $(0.14)$ \\
\hline Foreign & $\mathbf{0 . 9 0}^{*}$ & $0.97^{*}$ & $0.94^{*}$ \\
& $(0.22)$ & $(0.08)$ & $(0.19)$ \\
\hline
\end{tabular}

\begin{tabular}{|l|r|r|r|}
\hline 1998 & \multicolumn{1}{|l|}{ TE } & \multicolumn{1}{l|}{ PTE } & \multicolumn{1}{l|}{ Scale } \\
\hline All & $0.91^{*}$ & $1.00^{*}$ & $0.97^{*}$ \\
& 0.09 & 0.00 & 0.12 \\
\hline Big 4 & $0.87^{*}$ & $\mathbf{1 . 0 0}^{*}$ & $0.87^{*}$ \\
& 0.09 & 0.00 & 0.09 \\
\hline ODOM & $0.92^{*}$ & $\mathbf{1 . 0 0}$ & $0.98^{*}$ \\
& 0.08 & 0.00 & 0.12 \\
\hline Foreign & $\mathbf{0 . 9 5}^{*}$ & $\mathbf{1 . 0 0}^{*}$ & $\mathbf{1 . 0 5}^{*}$ \\
& 0.10 & 0.01 & 0.09 \\
\hline
\end{tabular}

\begin{tabular}{|l|r|r|r|}
\hline 1999 & \multicolumn{1}{|l|}{ TE } & \multicolumn{1}{l|}{ PTE } & \multicolumn{1}{l|}{ Scale } \\
\hline All & $0.91^{*}$ & $1.00^{*}$ & $0.98^{*}$ \\
& $(0.12)$ & $(0.02)$ & $(0.15)$ \\
\hline Big 4 & 0.90 & $\mathbf{1 . 0 0}^{*}$ & 0.90 \\
& $(0.14)$ & $(0.00)$ & $(0.14)$ \\
\hline ODOM & $0.91^{*}$ & $0.99^{*}$ & $0.98^{*}$ \\
& $(0.13)$ & $(0.03)$ & $(0.15)$ \\
\hline Foreign & $\mathbf{0 . 9 3}^{*}$ & $\mathbf{1 . 0 0}^{*}$ & $\mathbf{1 . 0 7}^{*}$ \\
& $(0.14)$ & $(0.00)$ & $(0.14)$ \\
\hline
\end{tabular}

\begin{tabular}{|l|r|r|r|}
\hline 2000 & \multicolumn{1}{|l|}{ TE } & \multicolumn{1}{l|}{ PTE } & \multicolumn{1}{l|}{ Scale } \\
\hline All & $0.97^{*}$ & $1.00^{*}$ & $0.97^{*}$ \\
& $(0.05)$ & $(0.00)$ & $(0.05)$ \\
\hline Big 4 & $0.94^{*}$ & $\mathbf{1 . 0 0}^{*}$ & $0.94^{*}$ \\
& $(0.06)$ & $(0.00)$ & $(0.06)$ \\
\hline ODOM & $0.98^{*}$ & $\mathbf{1 . 0 0}^{*}$ & $0.98^{*}$ \\
& $(0.04)$ & $(0.00)$ & $(0.04)$ \\
\hline Foreign & $\mathbf{1 . 0 0}^{*}$ & $\mathbf{1 . 0 0}^{*}$ & $\mathbf{1 . 0 0}^{*}$ \\
& $(0.00)$ & $(0.00)$ & $(0.00)$ \\
\hline
\end{tabular}

\begin{tabular}{|l|r|r|r|}
\hline 2001 & \multicolumn{1}{l|}{ TE } & \multicolumn{1}{l|}{ PTE } & \multicolumn{1}{l|}{ Scale } \\
\hline All & $0.96^{*}$ & $0.98^{*}$ & $0.99^{*}$ \\
& $(0.06)$ & $(0.04)$ & $(0.04)$ \\
\hline Big 4 & $0.96^{*}$ & $0.99^{*}$ & $0.97^{*}$ \\
& $(0.05)$ & $(0.02)$ & $(0.03)$ \\
\hline ODOM & $0.96^{*}$ & $0.98^{*}$ & $\mathbf{1 . 0 0}^{*}$ \\
& $(0.07)$ & $(0.05)$ & $(0.04)$ \\
\hline Foreign & $\mathbf{1 . 0 0}^{*}$ & $\mathbf{1 . 0 0}^{*}$ & $\mathbf{1 . 0 0}^{*}$ \\
& $(0.00)$ & $(0.00)$ & $(0.00)$ \\
\hline
\end{tabular}

Model 1b Inputs: (i) employees, (ii) deposits, (iii) equity capital. Outputs. (i) loans, (ii) investments, (iii) off balance sheet items. TE: Technical Efficiency, PTE: Pure Technical Efficiency, Scale: Scale Efficiency.

Values in bold are the largest for that category in that year. * Indicates maximum value of 1 for that category.

Scale Efficiency is calculated as decreasing return to scale; scale efficiency score unchanged; constant returns to scale score unchanged; increasing returns to scale, score transformed to (2- original score). Thus, an average scale efficiency score above 1 indicates increasing returns to scale on average, below one indicates decreasing returns to scale on average and a score of one indicates constant returns to scale on average.

Table A6

Average DEA Efficiency Scores: Model 2.

(Standard Deviations in Parentheses)

\begin{tabular}{|l|r|r|r|}
\hline Year & & & \\
\hline 1988 & \multicolumn{1}{|l|}{ TE } & \multicolumn{1}{|l|}{ PTE } & \multicolumn{1}{|c|}{ Scale } \\
\hline All & $0.81^{*}$ & $0.89^{*}$ & $1.01^{*}$ \\
& $(0.16)$ & $(0.15)$ & $(0.13)$ \\
\hline Big 4 & $\mathbf{0 . 9 1}$ & $\mathbf{1 . 0 0}^{*}$ & 0.91 \\
& $(0.01)$ & $(0.00)$ & $(0.01)$ \\
\hline ODOM & $0.84^{*}$ & $0.87^{*}$ & $0.96^{*}$ \\
& $(0.14)$ & $(0.12)$ & $(0.05)$ \\
\hline Foreign & $0.73^{*}$ & $0.85^{*}$ & $\mathbf{1 . 1 3}^{*}$ \\
& $(0.19)$ & $(0.19)$ & $(0.15)$ \\
\hline
\end{tabular}

\begin{tabular}{|l|r|r|r|}
\hline Year & & & \\
\hline 1989 & \multicolumn{1}{|l|}{ TE } & \multicolumn{1}{|c|}{ PTE } & \multicolumn{1}{|c|}{ Scale } \\
\hline All & $0.84^{*}$ & $0.90^{*}$ & $1.02^{*}$ \\
& $(0.13)$ & $(0.13)$ & $(0.10)$ \\
\hline Big 4 & $\mathbf{0 . 9 4}$ & $\mathbf{1 . 0 0}^{*}$ & 0.94 \\
& $(0.05)$ & $(0.00)$ & $(0.05)$ \\
\hline ODOM & $0.87^{*}$ & $0.89^{*}$ & $0.98^{*}$ \\
& $(0.12)$ & $(0.10)$ & $(0.04)$ \\
\hline Foreign & $0.76^{*}$ & $0.86^{*}$ & $\mathbf{1 . 1 0}^{*}$ \\
& $(0.14)$ & $(0.16)$ & $(0.12)$ \\
\hline
\end{tabular}

\begin{tabular}{|l|r|r|r|}
\hline 1990 & \multicolumn{1}{|l|}{ TE } & \multicolumn{1}{l|}{ PTE } & \multicolumn{1}{l|}{ Scale } \\
\hline All & $0.87^{*}$ & $0.94^{*}$ & $1.05^{*}$ \\
& $(0.15)$ & $(0.13)$ & $(0.13)$ \\
\hline
\end{tabular}

\begin{tabular}{|l|r|r|r|}
\hline 1991 & \multicolumn{1}{|l|}{ TE } & \multicolumn{1}{l|}{ PTE } & \multicolumn{1}{l|}{ Scale } \\
\hline All & $0.83^{*}$ & $0.90^{*}$ & $0.99^{*}$ \\
& $(0.14)$ & $(0.13)$ & $(0.12)$ \\
\hline
\end{tabular}




\begin{tabular}{|l|r|r|r|}
\hline Big 4 & $\begin{array}{c}\mathbf{0 . 9 6}^{*} \\
(0.04)\end{array}$ & $\begin{array}{c}\mathbf{1 . 0 0}^{*} \\
(0.00)\end{array}$ & $\begin{array}{c}0.96^{*} \\
(0.04)\end{array}$ \\
\hline ODOM & $0.92^{*}$ & $0.93^{*}$ & $0.99^{*}$ \\
& $(0.10)$ & $(0.10)$ & $(0.02)$ \\
\hline Foreign & $0.75^{*}$ & $0.92^{*}$ & $\mathbf{1 . 1 7}^{*}$ \\
& $(0.19)$ & $(0.18)$ & $(0.16)$ \\
\hline
\end{tabular}

\begin{tabular}{|l|r|r|r|}
\hline Big 4 & $\mathbf{0 . 9 0}$ & $\mathbf{1 . 0 0}^{*}$ & $\begin{array}{r}0.90 \\
(0.05)\end{array}$ \\
& $(0.00)$ & $(0.05)$ \\
\hline ODOM & $0.88^{*}$ & $0.92^{*}$ & $0.97^{*}$ \\
& $(0.12)$ & $(0.11)$ & $(0.06)$ \\
\hline Foreign & $0.71^{*}$ & $0.81^{*}$ & $\mathbf{1 . 0 7 *}$ \\
& $(0.14)$ & $(0.14)$ & $(0.17)$ \\
\hline
\end{tabular}

\begin{tabular}{|l|r|r|r|}
\hline 1992 & \multicolumn{1}{|l|}{ TE } & \multicolumn{1}{l|}{ PTE } & \multicolumn{1}{l|}{ Scale } \\
\hline All & $0.82^{*}$ & $0.91^{*}$ & $1.01^{*}$ \\
& $(0.17)$ & $(0.12)$ & $(0.16)$ \\
\hline Big 4 & $\mathbf{0 . 9 0}$ & $\mathbf{0 . 9 9} *$ & 0.91 \\
& $(0.05)$ & $(0.02)$ & $(0.03)$ \\
\hline ODOM & $0.81^{*}$ & $0.85^{*}$ & $0.95^{*}$ \\
& $(0.17)$ & $(0.14)$ & $(0.08)$ \\
\hline Foreign & $0.79^{*}$ & $0.94^{*}$ & $\mathbf{1 . 1 5 *}$ \\
& $(0.22)$ & $(0.10)$ & $(0.20)$ \\
\hline
\end{tabular}

\begin{tabular}{|l|r|r|r|}
\hline 1993 & \multicolumn{1}{|l|}{ TE } & \multicolumn{1}{l|}{ PTE } & \multicolumn{1}{l|}{ Scale } \\
\hline All & $0.67^{*}$ & $0.86^{*}$ & $0.91^{*}$ \\
& $(0.18)$ & $(0.16)$ & $(0.27)$ \\
\hline Big 4 & 0.57 & $\mathbf{1 . 0 0}^{*}$ & 0.57 \\
& $(0.05)$ & $(0.00)$ & $(0.05)$ \\
\hline ODOM & $0.66^{*}$ & $0.78^{*}$ & $0.86^{*}$ \\
& $(0.15)$ & $(0.17)$ & $(0.15)$ \\
\hline Foreign & $\mathbf{0 . 7 4}^{*}$ & $0.91^{*}$ & $\mathbf{1 . 1 8}^{*}$ \\
& $(0.25)$ & $(0.12)$ & $(0.24)$ \\
\hline
\end{tabular}

\begin{tabular}{|l|r|r|r|}
\hline 1994 & \multicolumn{1}{|l|}{ TE } & \multicolumn{1}{l|}{ PTE } & \multicolumn{1}{l|}{ Scale } \\
\hline All & $0.84^{*}$ & $0.91^{*}$ & $1.03^{*}$ \\
& $(0.12)$ & $(0.09)$ & $(0.13)$ \\
\hline Big 4 & $\mathbf{0 . 8 8}^{*}$ & $\mathbf{0 . 9 5}^{*}$ & $0.93^{*}$ \\
& $(0.09)$ & $(0.07)$ & $(0.09)$ \\
\hline ODOM & $0.86^{*}$ & $0.88^{*}$ & $1.00^{*}$ \\
& $(0.11)$ & $(0.10)$ & $(0.06)$ \\
\hline Foreign & $0.79^{*}$ & $0.93^{*}$ & $\mathbf{1 . 1 3}^{*}$ \\
& $(0.14)$ & $(0.09)$ & $(0.17)$ \\
\hline
\end{tabular}

\begin{tabular}{|l|r|r|r|}
\hline 1995 & \multicolumn{1}{|l|}{ TE } & \multicolumn{1}{l|}{ PTE } & \multicolumn{1}{l|}{ Scale } \\
\hline All & $0.88^{*}$ & $0.93^{*}$ & $1.01^{*}$ \\
& $(0.12)$ & $(0.08)$ & $(0.12)$ \\
\hline Big 4 & $\mathbf{0 . 9 4}^{*}$ & $\mathbf{0 . 9 8}^{*}$ & $0.96^{*}$ \\
& $(0.08)$ & $(0.02)$ & $(0.07)$ \\
\hline ODOM & $0.87^{*}$ & $0.90^{*}$ & $1.00^{*}$ \\
& $(0.10)$ & $(0.10)$ & $(0.05)$ \\
\hline Foreign & $0.86^{*}$ & $0.96^{*}$ & $\mathbf{1 . 0 9}^{*}$ \\
& $(0.19)$ & $(0.06)$ & $(0.20)$ \\
\hline
\end{tabular}

\begin{tabular}{|l|r|r|r|}
\hline 1996 & \multicolumn{1}{|l|}{ TE } & \multicolumn{1}{l|}{ PTE } & \multicolumn{1}{l|}{ Scale } \\
\hline All & $0.91^{*}$ & $0.93^{*}$ & $1.00^{*}$ \\
& $(0.09)$ & $(0.09)$ & $(0.04)$ \\
\hline Big 4 & $\mathbf{0 . 9 3}^{*}$ & $\mathbf{0 . 9 5}^{*}$ & $0.98^{*}$ \\
& $(0.09)$ & $(0.07)$ & $(0.02)$ \\
\hline ODOM & $0.90^{*}$ & $0.93^{*}$ & $\mathbf{1 . 0 0}^{*}$ \\
& $(0.08)$ & $(0.09)$ & $(0.05)$ \\
\hline Foreign & $0.92^{*}$ & $0.92^{*}$ & $\mathbf{1 . 0 0}^{*}$ \\
& $(0.12)$ & $(0.11)$ & $(0.01)$ \\
\hline
\end{tabular}

\begin{tabular}{|l|r|r|r|}
\hline 1997 & \multicolumn{1}{|l|}{ TE } & \multicolumn{1}{l|}{ PTE } & \multicolumn{1}{l|}{ Scale } \\
\hline All & $0.96^{*}$ & $0.98^{*}$ & $1.01^{*}$ \\
& $(0.05)$ & $(0.04)$ & $(0.03)$ \\
\hline Big 4 & $0.96^{*}$ & $0.96^{*}$ & $0.99^{*}$ \\
& $(0.05)$ & $(0.05)$ & $(0.01)$ \\
\hline ODOM & $0.96^{*}$ & $0.98^{*}$ & $\mathbf{1 . 0 2}^{*}$ \\
& $(0.05)$ & $(0.04)$ & $(0.03)$ \\
\hline Foreign & $\mathbf{0 . 9 8}^{*}$ & $\mathbf{0 . 9 9} *$ & $1.00^{*}$ \\
& $(0.03)$ & $(0.02)$ & $(0.01)$ \\
\hline
\end{tabular}

\begin{tabular}{|l|r|r|r|}
\hline 1998 & \multicolumn{1}{|l|}{ TE } & \multicolumn{1}{l|}{ PTE } & \multicolumn{1}{l|}{ Scale } \\
\hline All & $0.91^{*}$ & $0.94^{*}$ & $1.04^{*}$ \\
& $(0.14)$ & $(0.10)$ & $(0.09)$ \\
\hline Big 4 & $\mathbf{0 . 9 7}^{*}$ & $\mathbf{0 . 9 8}^{*}$ & $0.99^{*}$ \\
& $(0.04)$ & $(0.03)$ & $(0.01)$ \\
\hline ODOM & $0.89^{*}$ & $0.94^{*}$ & $\mathbf{1 . 0 6}^{*}$ \\
& $(0.17)$ & $(0.08)$ & $(0.12)$ \\
\hline Foreign & $0.88^{*}$ & $0.91^{*}$ & $1.02^{*}$ \\
& $(0.17)$ & $(0.17)$ & $(0.05)$ \\
\hline
\end{tabular}

\begin{tabular}{|l|r|r|r|}
\hline 1999 & \multicolumn{1}{|l|}{ TE } & \multicolumn{1}{l|}{ PTE } & \multicolumn{1}{l|}{ Scale } \\
\hline All & $0.88^{*}$ & $0.92^{*}$ & $1.01^{*}$ \\
& $(0.17)$ & $(0.15)$ & $(0.09)$ \\
\hline Big 4 & $\mathbf{0 . 9 8}^{*}$ & $\mathbf{0 . 9 8}^{*}$ & $1.00^{*}$ \\
& $(0.03)$ & $(0.03)$ & $(0.01)$ \\
\hline ODOM & $0.83^{*}$ & $0.90^{*}$ & $1.00^{*}$ \\
& $(0.22)$ & $(0.21)$ & $(0.13)$ \\
\hline Foreign & $0.87^{*}$ & $0.92^{*}$ & $\mathbf{1 . 0 5}^{*}$ \\
& $(0.12)$ & $(0.12)$ & $(0.05)$ \\
\hline
\end{tabular}

\begin{tabular}{|l|r|r|r|}
\hline 2000 & \multicolumn{1}{|l|}{ TE } & \multicolumn{1}{l|}{ PTE } & \multicolumn{1}{l|}{ Scale } \\
\hline All & $0.89^{*}$ & $0.92^{*}$ & $0.99^{*}$ \\
& $(0.18)$ & $(0.18)$ & $(0.05)$ \\
\hline Big 4 & $\mathbf{0 . 9 8}^{*}$ & $\mathbf{0 . 9 9}$ & $1.00^{*}$ \\
& $(0.03)$ & $(0.03)$ & $(0.01)$ \\
\hline ODOM & $0.82^{*}$ & $0.85^{*}$ & $0.97^{*}$ \\
& $(0.24)$ & $(0.24)$ & $(0.05)$ \\
\hline Foreign & 0.93 & $\mathbf{0 . 9 9} *$ & $\mathbf{1 . 0 2}$ \\
& $(0.04)$ & $(0.02)$ & $(0.07)$ \\
\hline
\end{tabular}

\begin{tabular}{|l|r|r|r|}
\hline 2001 & \multicolumn{1}{|l|}{ TE } & \multicolumn{1}{l|}{ PTE } & \multicolumn{1}{l|}{ Scale } \\
\hline All & $0.90^{*}$ & $0.92^{*}$ & $0.98^{*}$ \\
& $(0.16)$ & $(0.16)$ & $(0.03)$ \\
\hline Big 4 & $\mathbf{0 . 9 7}^{*}$ & $\mathbf{1 . 0 0}^{*}$ & $0.97^{*}$ \\
& $(0.06)$ & $(0.00)$ & $(0.06)$ \\
\hline ODOM & $0.87^{*}$ & $0.88^{*}$ & $\mathbf{0 . 9 8}$ \\
& $(0.19)$ & $(0.19)$ & $(0.02)$ \\
\hline Foreign & 0.91 & 0.95 & 0.96 \\
& $(0.00)$ & $(0.00)$ & $(0.00)$ \\
\hline
\end{tabular}

Model 2: Inputs: (i) interest expenses, (ii) non-interest expenses. Outputs: (i) net interest income, (ii) non-interest income. TE: Technical Efficiency, PTE: Pure Technical Efficiency, Scale: Scale Efficiency.

Values in bold are the largest for that category in that year. * Indicates maximum value of 1 for that category.

Scale Efficiency is calculated as decreasing return to scale; scale efficiency score unchanged; constant returns to scale score unchanged; increasing returns to scale, score transformed to (2- original score). Thus, an average scale efficiency score above 1 indicates increasing returns to scale on average, below one indicates decreasing returns to scale on average and a score of one indicates constant returns to scale on average. 
Table A7

DEA Scale Efficiency: Model 1a.

\begin{tabular}{|l|r|r|r|}
\hline Year & & & \\
\hline $\mathbf{1 9 8 8}$ & DRS & IRS & CRS \\
\hline All & 2 & 0 & 4 \\
\hline Big 4 & 2 & 0 & 0 \\
\hline ODOM & 0 & 0 & 1 \\
\hline Foreign & 0 & 0 & 3 \\
\hline
\end{tabular}

\begin{tabular}{|l|r|r|r|}
\hline Year & & & \\
\hline 1989 & DRS & IRS & CRS \\
\hline All & 8 & 3 & 7 \\
\hline Big 4 & 3 & 0 & 0 \\
\hline ODOM & 1 & 1 & 1 \\
\hline Foreign & 4 & 2 & 6 \\
\hline
\end{tabular}

\begin{tabular}{|l|r|r|r|}
\hline 1990 & DRS & \multicolumn{1}{|l|}{ IRS } & \multicolumn{1}{|c|}{ CRS } \\
\hline All & 6 & 5 & 12 \\
\hline Big 4 & 3 & 0 & 0 \\
\hline ODOM & 1 & 1 & 5 \\
\hline Foreign & 2 & 4 & 7 \\
\hline
\end{tabular}

\begin{tabular}{|l|r|r|r|}
\hline 1991 & \multicolumn{1}{|l|}{ DRS } & IRS & CRS \\
\hline All & 12 & 5 & 9 \\
\hline Big 4 & 4 & 0 & 0 \\
\hline ODOM & 7 & 0 & 2 \\
\hline Foreign & 1 & 5 & 7 \\
\hline
\end{tabular}

\begin{tabular}{|l|r|r|r|}
\hline 1992 & DRS & IRS & CRS \\
\hline All & 6 & 6 & 13 \\
\hline Big 4 & 2 & 0 & 2 \\
\hline ODOM & 3 & 1 & 5 \\
\hline Foreign & 1 & 5 & 6 \\
\hline
\end{tabular}

\begin{tabular}{|l|r|r|r|}
\hline 1993 & DRS & IRS & CRS \\
\hline All & 9 & 6 & 9 \\
\hline Big 4 & 4 & 0 & 0 \\
\hline ODOM & 4 & 2 & 3 \\
\hline Foreign & 1 & 4 & 6 \\
\hline
\end{tabular}

\begin{tabular}{|l|r|r|r|}
\hline 1994 & DRS & \multicolumn{1}{|l|}{ IRS } & \multicolumn{1}{|c|}{ CRS } \\
\hline All & 12 & 2 & 11 \\
\hline Big 4 & 4 & 0 & 0 \\
\hline ODOM & 4 & 1 & 5 \\
\hline Foreign & 4 & 1 & 6 \\
\hline
\end{tabular}

\begin{tabular}{|l|r|r|r|}
\hline 1995 & DRS & \multicolumn{1}{|l|}{ IRS } & CRS \\
\hline All & 10 & 2 & 11 \\
\hline Big 4 & 3 & 0 & 1 \\
\hline ODOM & 5 & 1 & 4 \\
\hline Foreign & 2 & 1 & 6 \\
\hline
\end{tabular}

\begin{tabular}{|l|r|r|r|}
\hline 1996 & DRS & IRS & CRS \\
\hline All & 8 & 4 & 8 \\
\hline Big 4 & 3 & 0 & 1 \\
\hline ODOM & 4 & 3 & 3 \\
\hline Foreign & 1 & 1 & 4 \\
\hline
\end{tabular}

\begin{tabular}{|l|r|r|r|}
\hline 1997 & DRS & IRS & CRS \\
\hline All & 8 & 4 & 5 \\
\hline Big 4 & 3 & 0 & 1 \\
\hline ODOM & 3 & 3 & 1 \\
\hline Foreign & 2 & 1 & 3 \\
\hline
\end{tabular}

\begin{tabular}{|l|r|r|r|}
\hline 1998 & DRS & IRS & CRS \\
\hline All & 4 & 3 & 6 \\
\hline Big 4 & 3 & 0 & 1 \\
\hline ODOM & 1 & 2 & 2 \\
\hline Foreign & 0 & 1 & 3 \\
\hline
\end{tabular}

\begin{tabular}{|l|r|r|r|}
\hline 1999 & DRS & IRS & CRS \\
\hline All & 4 & 3 & 6 \\
\hline Big 4 & 2 & 0 & 2 \\
\hline ODOM & 2 & 2 & 1 \\
\hline Foreign & 0 & 1 & 3 \\
\hline
\end{tabular}

\begin{tabular}{|l|r|r|r|}
\hline 2000 & DRS & IRS & CRS \\
\hline All & 3 & 0 & 7 \\
\hline Big 4 & 2 & 0 & 2 \\
\hline ODOM & 1 & 0 & 3 \\
\hline Foreign & 0 & 0 & 2 \\
\hline
\end{tabular}

\begin{tabular}{|l|r|r|r|}
\hline 2001 & DRS & IRS & CRS \\
\hline All & 3 & 1 & 6 \\
\hline Big 4 & 2 & 0 & 2 \\
\hline ODOM & 1 & 1 & 3 \\
\hline Foreign & 0 & 0 & 1 \\
\hline
\end{tabular}

DRS: Decreasing Returns to Scale; IRS: Increasing Returns to Scale; CRS: Constant Returns to Scale.

Model 1a: Inputs: (i) employees, (ii) deposits, (iii) equity capital. Outputs: (i) loans less housing loans, (ii) housing loans (iii) off balance sheet items.

Table A8

DEA Scale Efficiency: Model $1 \mathrm{~b}$.

\begin{tabular}{|l|r|r|r|}
\hline Year & & & \\
\hline 1988 & DRS & IRS & CRS \\
\hline All & 7 & 2 & 9 \\
\hline Big 4 & 2 & 0 & 0 \\
\hline ODOM & 0 & 1 & 2 \\
\hline
\end{tabular}

\begin{tabular}{|l|r|r|r|}
\hline Year & & & \\
\hline 1989 & DRS & IRS & CRS \\
\hline All & 9 & 6 & 11 \\
\hline Big 4 & 3 & 0 & 0 \\
\hline ODOM & 3 & 3 & 2 \\
\hline
\end{tabular}




\begin{tabular}{|l|r|r|r|}
\hline Foreign & 5 & 1 & 7 \\
\hline 1990 & DRS & \multicolumn{3}{|c|}{ IRS } & CRS \\
\hline All & 9 & 4 & 10 \\
\hline Big 4 & 3 & 0 & 0 \\
\hline ODOM & 3 & 2 & 2 \\
\hline Foreign & 3 & 2 & 8 \\
\hline
\end{tabular}

\begin{tabular}{|l|r|r|r|}
\hline Foreign & 3 & 3 & 9 \\
\hline 1991 & DRS & IRS & CRS \\
\hline All & 11 & 6 & 9 \\
\hline Big 4 & 4 & 0 & 0 \\
\hline ODOM & 4 & 2 & 3 \\
\hline Foreign & 3 & 4 & 6 \\
\hline
\end{tabular}

\begin{tabular}{|l|r|r|r|}
\hline 1992 & DRS & \multicolumn{1}{|l|}{ IRS } & CRS \\
\hline All & 14 & 4 & 7 \\
\hline Big 4 & 4 & 0 & 0 \\
\hline ODOM & 7 & 1 & 1 \\
\hline Foreign & 3 & 3 & 6 \\
\hline
\end{tabular}

\begin{tabular}{|l|r|r|r|}
\hline 1993 & DRS & IRS & CRS \\
\hline All & 11 & 4 & 9 \\
\hline Big 4 & 4 & 0 & 0 \\
\hline ODOM & 5 & 1 & 3 \\
\hline Foreign & 2 & 3 & 6 \\
\hline
\end{tabular}

\begin{tabular}{|l|r|r|r|}
\hline 1994 & DRS & \multicolumn{1}{|l|}{ IRS } & CRS \\
\hline All & 10 & 5 & 10 \\
\hline Big 4 & 4 & 0 & 0 \\
\hline ODOM & 5 & 3 & 2 \\
\hline Foreign & 1 & 2 & 8 \\
\hline
\end{tabular}

\begin{tabular}{|l|r|r|r|}
\hline 1995 & DRS & \multicolumn{1}{|l|}{ IRS } & CRS \\
\hline All & 13 & 2 & 8 \\
\hline Big 4 & 3 & 0 & 1 \\
\hline ODOM & 8 & 1 & 1 \\
\hline Foreign & 2 & 1 & 6 \\
\hline
\end{tabular}

\begin{tabular}{|l|r|r|r|}
\hline 1996 & DRS & IRS & CRS \\
\hline All & 8 & 6 & 6 \\
\hline Big 4 & 4 & 0 & 0 \\
\hline ODOM & 4 & 5 & 1 \\
\hline Foreign & 0 & 1 & 5 \\
\hline
\end{tabular}

\begin{tabular}{|l|r|r|r|}
\hline 1997 & DRS & IRS & CRS \\
\hline All & 7 & 5 & 5 \\
\hline Big 4 & 3 & 0 & 1 \\
\hline ODOM & 3 & 4 & 0 \\
\hline Foreign & 1 & 1 & 4 \\
\hline
\end{tabular}

\begin{tabular}{|l|r|r|r|}
\hline 1998 & DRS & IRS & CRS \\
\hline All & 5 & 4 & 4 \\
\hline Big 4 & 3 & 0 & 1 \\
\hline ODOM & 2 & 2 & 1 \\
\hline Foreign & 0 & 2 & 2 \\
\hline
\end{tabular}

\begin{tabular}{|l|r|r|r|}
\hline 1999 & DRS & IRS & CRS \\
\hline All & 5 & 2 & 6 \\
\hline Big 4 & 4 & 0 & 0 \\
\hline ODOM & 1 & 1 & 3 \\
\hline Foreign & 0 & 1 & 3 \\
\hline
\end{tabular}

\begin{tabular}{|l|r|r|r|}
\hline 2000 & DRS & IRS & CRS \\
\hline All & 4 & 0 & 6 \\
\hline Big 4 & 3 & 0 & 1 \\
\hline ODOM & 1 & 0 & 3 \\
\hline Foreign & 0 & 0 & 2 \\
\hline
\end{tabular}

\begin{tabular}{|l|r|r|r|}
\hline 2001 & DRS & IRS & CRS \\
\hline All & 3 & 1 & 6 \\
\hline Big 4 & 2 & 0 & 2 \\
\hline ODOM & 1 & 1 & 3 \\
\hline Foreign & 0 & 0 & 1 \\
\hline
\end{tabular}

DRS: Decreasing Returns to Scale; IRS: Increasing Returns to Scale; CRS: Constant Returns to Scale.

Model 1b Inputs: (i) employees, (ii) deposits, (iii) equity capital. Outputs: (i) loans, (ii) investments, (iii) off balance sheet items.

Table A9

DEA Scale Efficiency: Model 2.

\begin{tabular}{|l|r|r|r|}
\hline Year & & & \\
\hline 1988 & DRS & IRS & CRS \\
\hline All & 10 & 4 & 5 \\
\hline Big 4 & 4 & 0 & 0 \\
\hline ODOM & 5 & 0 & 3 \\
\hline Foreign & 1 & 4 & 2 \\
\hline
\end{tabular}

\begin{tabular}{|l|r|r|r|}
\hline Year & & & \\
\hline 1989 & DRS & IRS & CRS \\
\hline All & 8 & 8 & 5 \\
\hline Big 4 & 4 & 0 & 0 \\
\hline ODOM & 4 & 2 & 3 \\
\hline Foreign & 0 & 6 & 2 \\
\hline
\end{tabular}

\begin{tabular}{|l|r|r|r|}
\hline 1990 & DRS & \multicolumn{1}{|l|}{ IRS } & CRS \\
\hline All & 10 & 6 & 4 \\
\hline Big 4 & 3 & 0 & 1 \\
\hline ODOM & 7 & 0 & 2 \\
\hline Foreign & 0 & 6 & 1 \\
\hline
\end{tabular}

\begin{tabular}{|l|r|r|r|}
\hline 1991 & DRS & \multicolumn{1}{|l|}{ IRS } & CRS \\
\hline All & 13 & 4 & 4 \\
\hline Big 4 & 4 & 0 & 0 \\
\hline ODOM & 6 & 1 & 3 \\
\hline Foreign & 3 & 3 & 1 \\
\hline
\end{tabular}




\begin{tabular}{|l|r|r|r|} 
1992 & DRS & IRS & CRS \\
\hline All & 10 & 6 & 5 \\
\hline Big 4 & 4 & 0 & 0 \\
\hline ODOM & 5 & 2 & 3 \\
\hline Foreign & 1 & 4 & 2 \\
\hline
\end{tabular}

\begin{tabular}{|l|r|r|r|} 
1993 & DRS & IRS & CRS \\
\hline All & 14 & 6 & 3 \\
\hline Big 4 & 4 & 0 & 0 \\
\hline ODOM & 9 & 2 & 1 \\
\hline Foreign & 1 & 4 & 2 \\
\hline
\end{tabular}

\begin{tabular}{|l|r|r|r|}
\hline 1994 & DRS & IRS & CRS \\
\hline All & 6 & 12 & 3 \\
\hline Big 4 & 3 & 0 & 1 \\
\hline ODOM & 2 & 7 & 1 \\
\hline Foreign & 1 & 5 & 1 \\
\hline
\end{tabular}

\begin{tabular}{|l|r|r|r|}
\hline 1995 & DRS & IRS & CRS \\
\hline All & 5 & 9 & 6 \\
\hline Big 4 & 2 & 0 & 2 \\
\hline ODOM & 3 & 6 & 2 \\
\hline Foreign & 0 & 3 & 2 \\
\hline
\end{tabular}

\begin{tabular}{|l|r|r|r|}
\hline 1996 & DRS & IRS & CRS \\
\hline All & 7 & 5 & 8 \\
\hline Big 4 & 2 & 0 & 2 \\
\hline ODOM & 4 & 5 & 2 \\
\hline Foreign & 1 & 0 & 4 \\
\hline
\end{tabular}

\begin{tabular}{|l|r|r|r|}
\hline 1997 & DRS & IRS & CRS \\
\hline All & 3 & 5 & 8 \\
\hline Big 4 & 2 & 0 & 2 \\
\hline ODOM & 0 & 4 & 4 \\
\hline Foreign & 1 & 1 & 2 \\
\hline
\end{tabular}

\begin{tabular}{|l|r|r|r|}
\hline 1998 & DRS & IRS & CRS \\
\hline All & 4 & 7 & 7 \\
\hline Big 4 & 2 & 0 & 2 \\
\hline ODOM & 0 & 5 & 4 \\
\hline Foreign & 2 & 2 & 1 \\
\hline
\end{tabular}

\begin{tabular}{|l|r|r|r|}
\hline 1999 & DRS & IRS & CRS \\
\hline All & 4 & 6 & 6 \\
\hline Big 4 & 2 & 0 & 2 \\
\hline ODOM & 1 & 3 & 3 \\
\hline Foreign & 1 & 3 & 1 \\
\hline
\end{tabular}

\begin{tabular}{|l|r|r|r|}
\hline 2000 & DRS & IRS & CRS \\
\hline All & 5 & 5 & 6 \\
\hline Big 4 & 1 & 0 & 3 \\
\hline ODOM & 3 & 2 & 3 \\
\hline Foreign & 1 & 3 & 0 \\
\hline
\end{tabular}

\begin{tabular}{|l|r|r|r|}
\hline 2001 & DRS & IRS & CRS \\
\hline All & 8 & 0 & 5 \\
\hline Big 4 & 2 & 0 & 2 \\
\hline ODOM & 5 & 0 & 3 \\
\hline Foreign & 1 & 0 & 0 \\
\hline
\end{tabular}

DRS: Decreasing Returns to Scale; IRS: Increasing Returns to Scale; CRS: Constant Returns to Scale.

Model 2: Inputs: (i) interest expenses, (ii) non-interest expenses. Outputs: (i) net interest income, (ii) noninterest income.

Table A10

Malmquist Indices by Year. Model 1.

\begin{tabular}{|l|l|c|c|c|c|c|}
\hline & & Effch & TechCh & Pech & Sech & TfpCh \\
\hline $\mathbf{1 9 9 0}$ & All & 0.73 & 1.17 & 0.99 & 0.74 & 0.85 \\
& (Std Dev) & $(0.26)$ & $(0.40)$ & $(0.06)$ & $(0.26)$ & $(0.58)$ \\
\hline & Big 4 & $\mathbf{0 . 7 5}$ & $\mathbf{1 . 3 1}$ & 1.00 & $\mathbf{0 . 7 5}$ & $\mathbf{0 . 9 8}$ \\
& (Std Dev) & $(0.34)$ & $(0.54)$ & $(0.00)$ & $(0.34)$ & $(0.81)$ \\
\hline & Other Domestic & 0.74 & 1.17 & $\mathbf{1 . 0 1}$ & 0.73 & 0.86 \\
& (Std Dev) & $(0.25)$ & $(0.39)$ & $(0.04)$ & $(0.25)$ & $(0.56)$ \\
\hline & Foreign & 0.72 & 1.11 & 0.97 & 0.74 & 0.80 \\
& (Std Dev) & $(0.28)$ & $(0.39)$ & $(0.08)$ & $(0.26)$ & $(0.56)$ \\
\hline $\mathbf{1 9 9 1}$ & All & 1.29 & 1.79 & 0.98 & 1.32 & 2.31 \\
& (Std Dev) & $(0.60)$ & $(0.92)$ & $(0.10)$ & $(0.58)$ & $(1.17)$ \\
\hline & Big 4 & $\mathbf{1 . 3 2}$ & 1.64 & 1.00 & $\mathbf{1 . 3 3}$ & 2.17 \\
& (Std Dev) & $(0.82)$ & $(1.22)$ & $(0.01)$ & $(0.82)$ & $(0.92)$ \\
\hline & Other Domestic & 1.24 & 1.55 & 0.93 & $\mathbf{1 . 3 3}$ & 1.92 \\
& (Std Dev) & $(0.45)$ & $(0.79)$ & $(0.09)$ & $(0.53)$ & $(0.58)$ \\
\hline & Foreign & $\mathbf{1 . 3 2}$ & $\mathbf{2 . 0 7}$ & $\mathbf{1 . 0 1}$ & 1.30 & $\mathbf{2 . 7 2}$ \\
& (Std Dev) & $(0.69)$ & $(0.95)$ & $(0.12)$ & $(0.62)$ & $(1.48)$ \\
\hline $\mathbf{1 9 9 2}$ & All & 1.02 & 0.91 & 1.02 & 1.00 & 0.93 \\
& (Std Dev) & $(0.18)$ & $(0.25)$ & $(0.12)$ & $(0.10)$ & $(0.36)$ \\
\hline & Big 4 & 0.87 & 0.88 & 0.97 & 0.89 & 0.76 \\
& (Std Dev) & $(0.17)$ & $(0.26)$ & $(0.06)$ & $(0.18)$ & $(0.17)$ \\
\hline & Other Domestic & $\mathbf{1 . 0 9}$ & $\mathbf{1 . 0 1}$ & $\mathbf{1 . 0 6}$ & $\mathbf{1 . 0 3}$ & $\mathbf{1 . 1 0}$ \\
& (Std Dev) & $(0.16)$ & $(0.25)$ & $(0.14)$ & $(0.02)$ & $(0.38)$ \\
\hline & Foreign & 1.03 & 0.86 & 1.00 & $\mathbf{1 . 0 3}$ & 0.89 \\
\hline
\end{tabular}




\begin{tabular}{|c|c|c|c|c|c|c|}
\hline & (Std Dev) & $(0.19)$ & $(0.27)$ & $(0.13)$ & $(0.08)$ & $(0.38)$ \\
\hline \multirow[t]{4}{*}{1993} & $\begin{array}{l}\text { All } \\
(\text { Std Dev) }\end{array}$ & $\begin{array}{c}0.91 \\
(0.18)\end{array}$ & $\begin{array}{c}1.33 \\
(0.36) \\
\end{array}$ & $\begin{array}{c}1.02 \\
(0.07)\end{array}$ & $\begin{array}{c}0.89 \\
(0.16) \\
\end{array}$ & $\begin{array}{c}1.21 \\
(0.51)\end{array}$ \\
\hline & $\begin{array}{l}\text { Big } 4 \\
\text { (Std Dev) }\end{array}$ & $\begin{array}{c}0.84 \\
(0.22)\end{array}$ & $\begin{array}{c}1.23 \\
(0.09)\end{array}$ & $\begin{array}{c}0.99 \\
(0.10)\end{array}$ & $\begin{array}{c}0.85 \\
(0.24)\end{array}$ & $\begin{array}{c}1.04 \\
(0.27)\end{array}$ \\
\hline & $\begin{array}{l}\text { Other Domestic } \\
\text { (Std Dev) }\end{array}$ & $\begin{array}{c}\mathbf{0 . 9 5} \\
(0.14)\end{array}$ & $\begin{array}{c}1.25 \\
(0.43)\end{array}$ & $\begin{array}{c}1.02 \\
(0.04)\end{array}$ & $\begin{array}{c}\mathbf{0 . 9 3} \\
(0.12)\end{array}$ & $\begin{array}{c}1.18 \\
(0.53)\end{array}$ \\
\hline & $\begin{array}{l}\text { Foreign } \\
(\text { Std Dev) }\end{array}$ & $\begin{array}{c}0.91 \\
(0.20) \\
\end{array}$ & $\begin{array}{c}\mathbf{1 . 4 4} \\
(0.38) \\
\end{array}$ & $\begin{array}{c}\mathbf{1 . 0 4} \\
(0.07) \\
\end{array}$ & $\begin{array}{c}0.87 \\
(0.16) \\
\end{array}$ & $\begin{array}{c}\mathbf{1 . 3 1} \\
(0.60) \\
\end{array}$ \\
\hline \multirow[t]{4}{*}{1994} & $\begin{array}{l}\text { All } \\
(\text { Std Dev) }\end{array}$ & $\begin{array}{c}0.99 \\
(0.30)\end{array}$ & $\begin{array}{c}0.70 \\
(0.25) \\
\end{array}$ & $\begin{array}{c}0.97 \\
(0.06) \\
\end{array}$ & $\begin{array}{c}1.02 \\
(0.28) \\
\end{array}$ & $\begin{array}{c}0.70 \\
(0.47) \\
\end{array}$ \\
\hline & $\begin{array}{l}\text { Big } 4 \\
\text { (Std Dev) }\end{array}$ & $\begin{array}{c}1.33 \\
(0.32) \\
\end{array}$ & $\begin{array}{c}\mathbf{0 . 9 5} \\
(0.18) \\
\end{array}$ & $\begin{array}{c}\mathbf{1 . 0 4} \\
(0.06) \\
\end{array}$ & $\begin{array}{c}\mathbf{1 . 2 8} \\
(0.30) \\
\end{array}$ & $\begin{array}{c}1.27 \\
(0.53) \\
\end{array}$ \\
\hline & $\begin{array}{l}\text { Other Domestic } \\
\text { (Std Dev) }\end{array}$ & $\begin{array}{c}0.80 \\
(0.30)\end{array}$ & $\begin{array}{c}0.66 \\
(0.24) \\
\end{array}$ & $\begin{array}{c}0.96 \\
(0.05)\end{array}$ & $\begin{array}{c}0.83 \\
(0.28) \\
\end{array}$ & $\begin{array}{c}0.53 \\
(0.39) \\
\end{array}$ \\
\hline & $\begin{array}{l}\text { Foreign } \\
(\text { Std Dev) }\end{array}$ & $\begin{array}{c}1.02 \\
(0.17)\end{array}$ & $\begin{array}{c}0.64 \\
(0.25) \\
\end{array}$ & $\begin{array}{c}0.95 \\
(0.06)\end{array}$ & $\begin{array}{c}1.07 \\
(0.19) \\
\end{array}$ & $\begin{array}{c}0.66 \\
(0.36) \\
\end{array}$ \\
\hline \multirow[t]{4}{*}{1995} & $\begin{array}{l}\text { All } \\
(\text { Std Dev) }\end{array}$ & $\begin{array}{c}1.05 \\
(0.29)\end{array}$ & $\begin{array}{c}1.12 \\
(0.38) \\
\end{array}$ & $\begin{array}{c}1.02 \\
(0.07)\end{array}$ & $\begin{array}{c}1.03 \\
(0.24) \\
\end{array}$ & $\begin{array}{c}1.17 \\
(0.48) \\
\end{array}$ \\
\hline & $\begin{array}{l}\text { Big } 4 \\
(\text { Std Dev) }\end{array}$ & $\begin{array}{c}0.90 \\
(0.12)\end{array}$ & $\begin{array}{c}1.18 \\
(0.23) \\
\end{array}$ & $\begin{array}{c}0.97 \\
(0.05) \\
\end{array}$ & $\begin{array}{c}0.93 \\
(0.08) \\
\end{array}$ & $\begin{array}{c}1.06 \\
(0.09) \\
\end{array}$ \\
\hline & $\begin{array}{l}\text { Other Domestic } \\
\text { (Std Dev) }\end{array}$ & $\begin{array}{c}\mathbf{1 . 2 0} \\
(0.35) \\
\end{array}$ & $\begin{array}{c}\mathbf{1 . 2 2} \\
(0.58) \\
\end{array}$ & $\begin{array}{c}1.03 \\
(0.06) \\
\end{array}$ & $\begin{array}{c}\mathbf{1 . 1 6} \\
(0.32) \\
\end{array}$ & $\begin{array}{r}1.46 \\
(0.71) \\
\end{array}$ \\
\hline & $\begin{array}{l}\text { Foreign } \\
(\text { Std Dev) }\end{array}$ & $\begin{array}{c}1.02 \\
(0.27) \\
\end{array}$ & $\begin{array}{c}1.03 \\
(0.28) \\
\end{array}$ & $\begin{array}{c}\mathbf{1 . 0 4} \\
(0.08) \\
\end{array}$ & $\begin{array}{c}0.98 \\
(0.19) \\
\end{array}$ & $\begin{array}{c}1.05 \\
(0.22) \\
\end{array}$ \\
\hline
\end{tabular}

Model 1: Inputs: (i) employees, (ii) deposits, (iii) equity capital. Outputs: (i) loans, (ii) off balance sheet items.Effch: technical efficiency change relative to constant returns to scale technology. Techch: technological change. Pech: pure technical efficiency change relative to variable returns to scale technology. Sech: scale efficiency change. Tfpch: total factor productivity change. Effch $=$ Pech $*$ Sech. Tfpch $=$ Effch $*$ Techch. (There are some small differences due to rounding.)

Table A11

Malmquist Indices by Year. Model 1a.

\begin{tabular}{|c|c|c|c|c|c|c|}
\hline & & Effch & TechCh & Pech & Sech & TfpCh \\
\hline \multirow[t]{4}{*}{1991} & $\begin{array}{l}\text { All } \\
\text { (Std Dev) }\end{array}$ & $\begin{array}{c}0.80 \\
(0.22)\end{array}$ & $\begin{array}{c}0.98 \\
(0.38)\end{array}$ & $\begin{array}{c}0.98 \\
(0.06)\end{array}$ & $\begin{array}{c}0.81 \\
(0.21)\end{array}$ & $\begin{array}{c}0.78 \\
(0.40)\end{array}$ \\
\hline & $\begin{array}{l}\text { Big } 4 \\
\text { (Std Dev) }\end{array}$ & $\begin{array}{c}\mathbf{0 . 9 7} \\
(0.05)\end{array}$ & $\begin{array}{c}0.93 \\
(0.48)\end{array}$ & $\begin{array}{c}\mathbf{1 . 0 0} \\
(0.00)\end{array}$ & $\begin{array}{c}\mathbf{0 . 9 7} \\
(0.05)\end{array}$ & $\begin{array}{c}\mathbf{0 . 9 0} \\
(0.48)\end{array}$ \\
\hline & $\begin{array}{l}\text { Other Domestic } \\
\text { (Std Dev) }\end{array}$ & $\begin{array}{c}0.77 \\
(0.29)\end{array}$ & $\begin{array}{c}0.90 \\
(0.36)\end{array}$ & $\begin{array}{c}0.98 \\
(0.06)\end{array}$ & $\begin{array}{c}0.78 \\
(0.27)\end{array}$ & $\begin{array}{c}0.69 \\
(0.31)\end{array}$ \\
\hline & $\begin{array}{l}\text { Foreign } \\
(\text { Std Dev) }\end{array}$ & $\begin{array}{c}0.77 \\
(0.20)\end{array}$ & $\begin{array}{c}\mathbf{1 . 0 8} \\
(0.40)\end{array}$ & $\begin{array}{c}0.98 \\
(0.08)\end{array}$ & $\begin{array}{c}0.78 \\
(0.18)\end{array}$ & $\begin{array}{c}0.82 \\
(0.46)\end{array}$ \\
\hline \multirow[t]{4}{*}{1992} & $\begin{array}{l}\text { All } \\
\text { (Std Dev) }\end{array}$ & $\begin{array}{c}1.18 \\
(0.47)\end{array}$ & $\begin{array}{c}1.92 \\
(1.50)\end{array}$ & $\begin{array}{c}1.01 \\
(0.05)\end{array}$ & $\begin{array}{c}1.17 \\
(0.42)\end{array}$ & $\begin{array}{c}2.26 \\
(2.99)\end{array}$ \\
\hline & $\begin{array}{l}\text { Big } 4 \\
\text { (Std Dev) }\end{array}$ & $\begin{array}{c}1.02 \\
(0.06)\end{array}$ & $\begin{array}{c}1.03 \\
(1.04)\end{array}$ & $\begin{array}{c}1.00 \\
(0.00)\end{array}$ & $\begin{array}{c}1.02 \\
(0.06)\end{array}$ & $\begin{array}{c}1.06 \\
(1.02)\end{array}$ \\
\hline & $\begin{array}{l}\text { Other Domestic } \\
\text { (Std Dev) }\end{array}$ & $\begin{array}{c}\mathbf{1 . 3 0} \\
(0.65)\end{array}$ & $\begin{array}{c}2.01 \\
(1.47)\end{array}$ & $\begin{array}{c}\mathbf{1 . 0 2} \\
(0.06)\end{array}$ & $\begin{array}{c}\mathbf{1 . 2 6} \\
(0.57)\end{array}$ & $\begin{array}{c}2.60 \\
(3.88)\end{array}$ \\
\hline & $\begin{array}{l}\text { Foreign } \\
\text { (Std Dev) }\end{array}$ & $\begin{array}{c}1.15 \\
(0.38)\end{array}$ & $\begin{array}{c}\mathbf{2 . 4 1} \\
(1.60)\end{array}$ & $\begin{array}{c}1.00 \\
(0.06)\end{array}$ & $\begin{array}{c}1.16 \\
(0.38)\end{array}$ & $\begin{array}{c}\mathbf{2 . 7 8} \\
(2.63)\end{array}$ \\
\hline \multirow[t]{4}{*}{1993} & $\begin{array}{l}\text { All } \\
\text { (Std Dev) }\end{array}$ & $\begin{array}{c}1.01 \\
(0.20)\end{array}$ & $\begin{array}{c}1.38 \\
(0.36)\end{array}$ & $\begin{array}{c}0.99 \\
(0.07)\end{array}$ & $\begin{array}{c}1.02 \\
(0.17)\end{array}$ & $\begin{array}{c}1.39 \\
(0.45)\end{array}$ \\
\hline & $\begin{array}{l}\text { Big } 4 \\
\text { (Std Dev) }\end{array}$ & $\begin{array}{c}0.91 \\
(0.13)\end{array}$ & $\begin{array}{c}1.30 \\
(0.53)\end{array}$ & $\begin{array}{c}0.97 \\
(0.05)\end{array}$ & $\begin{array}{c}0.94 \\
(0.09)\end{array}$ & $\begin{array}{c}1.19 \\
(0.54)\end{array}$ \\
\hline & $\begin{array}{l}\text { Other Domestic } \\
\text { (Std Dev) }\end{array}$ & $\begin{array}{c}0.93 \\
(0.06)\end{array}$ & $\begin{array}{c}1.33 \\
(0.26)\end{array}$ & $\begin{array}{c}0.95 \\
(0.05)\end{array}$ & $\begin{array}{c}0.98 \\
(0.06)\end{array}$ & $\begin{array}{c}1.24 \\
(0.22)\end{array}$ \\
\hline & $\begin{array}{l}\text { Foreign } \\
\text { (Std Dev) }\end{array}$ & $\begin{array}{c}1.13 \\
(0.25)\end{array}$ & $\begin{array}{c}\mathbf{1 . 4 5} \\
(0.40)\end{array}$ & $\begin{array}{l}\mathbf{1 . 0 3} \\
(0.07)\end{array}$ & $\begin{array}{c}\mathbf{1 . 0 9} \\
(0.23)\end{array}$ & $\begin{array}{c}\mathbf{1 . 6 4} \\
(0.48)\end{array}$ \\
\hline \multirow[t]{4}{*}{1994} & $\begin{array}{l}\text { All } \\
\text { (Std Dev) }\end{array}$ & $\begin{array}{c}0.96 \\
(0.19)\end{array}$ & $\begin{array}{c}0.58 \\
(0.10)\end{array}$ & $\begin{array}{c}0.97 \\
(0.14)\end{array}$ & $\begin{array}{c}0.99 \\
(0.11)\end{array}$ & $\begin{array}{c}0.56 \\
(0.13)\end{array}$ \\
\hline & $\begin{array}{l}\text { Big } 4 \\
\text { (Std Dev) }\end{array}$ & $\begin{array}{c}\mathbf{1 . 1 1} \\
(0.17)\end{array}$ & $\begin{array}{c}\mathbf{0 . 6 6} \\
(0.05)\end{array}$ & $\begin{array}{l}\mathbf{1 . 0 3} \\
(0.05)\end{array}$ & $\begin{array}{c}\mathbf{1 . 0 8} \\
(0.10)\end{array}$ & $\begin{array}{c}\mathbf{0 . 7 3} \\
(0.06)\end{array}$ \\
\hline & $\begin{array}{l}\text { Other Domestic } \\
\text { (Std Dev) }\end{array}$ & $\begin{array}{c}0.94 \\
(0.18) \\
\end{array}$ & $\begin{array}{c}0.55 \\
(0.11) \\
\end{array}$ & $\begin{array}{c}1.02 \\
(0.05) \\
\end{array}$ & $\begin{array}{c}0.92 \\
(0.15) \\
\end{array}$ & $\begin{array}{c}0.52 \\
(0.09) \\
\end{array}$ \\
\hline & Foreign & 0.92 & 0.57 & 0.91 & 1.01 & 0.52 \\
\hline
\end{tabular}




\begin{tabular}{|l|l|c|c|c|c|c|}
\hline & (Std Dev) & $(0.20)$ & $(0.10)$ & $(0.19)$ & $(0.03)$ & $(0.15)$ \\
\hline $\mathbf{1 9 9 5}$ & All & 1.07 & 1.01 & 1.04 & 1.03 & 1.08 \\
& (Std Dev) & $(0.31)$ & $(0.37)$ & $(0.26)$ & $(0.17)$ & $(0.46)$ \\
\hline & Big 4 & 0.91 & 0.89 & 0.96 & 0.95 & 0.81 \\
& (Std Dev) & $(0.09)$ & $(0.34)$ & $(0.04)$ & $(0.09)$ & $(0.39)$ \\
\hline & Other Domestic & $\mathbf{1 . 1 6}$ & 0.91 & 1.03 & $\mathbf{1 . 1 3}$ & 1.05 \\
& (Std Dev) & $(0.25)$ & $(0.38)$ & $(0.05)$ & $(0.23)$ & $(0.52)$ \\
\hline & Foreign & 1.08 & $\mathbf{1 . 1 7}$ & $\mathbf{1 . 1 0}$ & 0.98 & $\mathbf{1 . 2 6}$ \\
& (Std Dev) & $(0.40)$ & $(0.38)$ & $(0.39)$ & $(0.04)$ & $(0.43)$ \\
\hline
\end{tabular}

Model 1a: Inputs: (i) employees, (ii) deposits, (iii) equity capital. Outputs: (i) loans less housing loans, (ii) housing loans (iii) off balance sheet items.

Effch: technical efficiency change relative to constant returns to scale technology. Techch: technological change. Pech: pure technical efficiency change relative to variable returns to scale technology. Sech: scale efficiency change. Tfpch: total factor productivity change. Effch $=$ Pech $*$ Sech. Tfpch $=$ Effch $*$ Techch. (There are some small differences due to rounding.)

Table A12

Malmquist Indices by Year. Model 1 b.

\begin{tabular}{|c|c|c|c|c|c|c|}
\hline & & Effch & TechCh & Pech & Sech & TfpCh \\
\hline \multirow[t]{4}{*}{1990} & $\begin{array}{l}\text { All } \\
\text { (Std Dev) }\end{array}$ & $\begin{array}{c}1.00 \\
(0.05)\end{array}$ & $\begin{array}{c}1.04 \\
(0.43)\end{array}$ & $\begin{array}{c}1.01 \\
(0.03)\end{array}$ & $\begin{array}{c}0.99 \\
(0.03)\end{array}$ & $\begin{array}{c}1.03 \\
(0.41)\end{array}$ \\
\hline & $\begin{array}{l}\text { Big } 4 \\
\text { (Std Dev) } \\
\end{array}$ & $\begin{array}{c}\mathbf{1 . 0 0} \\
(0.00) \\
\end{array}$ & $\begin{array}{c}\mathbf{1 . 1 4} \\
(0.45) \\
\end{array}$ & $\begin{array}{c}1.00 \\
(0.00) \\
\end{array}$ & $\begin{array}{c}\mathbf{1 . 0 0} \\
(0.00) \\
\end{array}$ & $\begin{array}{c}\mathbf{1 . 1 4} \\
(0.45) \\
\end{array}$ \\
\hline & $\begin{array}{l}\text { Other Domestic } \\
\text { (Std Dev) }\end{array}$ & $\begin{array}{c}0.99 \\
(0.06)\end{array}$ & $\begin{array}{c}1.07 \\
(0.45)\end{array}$ & $\begin{array}{c}\mathbf{1 . 0 2} \\
(0.03)\end{array}$ & $\begin{array}{c}0.98 \\
(0.04)\end{array}$ & $\begin{array}{c}1.06 \\
(0.41)\end{array}$ \\
\hline & $\begin{array}{l}\text { Foreign } \\
(\text { Std Dev) }\end{array}$ & $\begin{array}{c}\mathbf{1 . 0 0} \\
(0.06)\end{array}$ & $\begin{array}{c}0.97 \\
(0.47)\end{array}$ & $\begin{array}{c}1.01 \\
(0.04)\end{array}$ & $\begin{array}{c}0.98 \\
(0.04)\end{array}$ & $\begin{array}{c}0.97 \\
(0.45)\end{array}$ \\
\hline \multirow[t]{4}{*}{1991} & $\begin{array}{l}\text { All } \\
\text { (Std Dev) }\end{array}$ & $\begin{array}{c}0.97 \\
(0.09)\end{array}$ & $\begin{array}{c}2.13 \\
(0.90)\end{array}$ & $\begin{array}{c}0.96 \\
(0.07)\end{array}$ & $\begin{array}{l}1.00 \\
(0.04)\end{array}$ & $\begin{array}{c}2.06 \\
(0.99)\end{array}$ \\
\hline & $\begin{array}{l}\text { Big } 4 \\
\text { (Std Dev) }\end{array}$ & $\begin{array}{c}\mathbf{1 . 0 0} \\
(0.00) \\
\end{array}$ & $\begin{array}{c}1.90 \\
(1.06) \\
\end{array}$ & $\begin{array}{c}\mathbf{1 . 0 0} \\
(0.00) \\
\end{array}$ & $\begin{array}{c}\mathbf{1 . 0 0} \\
(0.00) \\
\end{array}$ & $\begin{array}{c}1.90 \\
(1.06) \\
\end{array}$ \\
\hline & $\begin{array}{l}\text { Other Domestic } \\
\text { (Std Dev) }\end{array}$ & $\begin{array}{c}0.94 \\
(0.12) \\
\end{array}$ & $\begin{array}{c}1.87 \\
(0.82)\end{array}$ & $\begin{array}{c}0.94 \\
(0.09)\end{array}$ & $\begin{array}{c}\mathbf{1 . 0 0} \\
(0.06)\end{array}$ & $\begin{array}{c}1.76 \\
(0.96)\end{array}$ \\
\hline & $\begin{array}{l}\text { Foreign } \\
(\text { Std Dev) }\end{array}$ & $\begin{array}{c}0.97 \\
(0.09)\end{array}$ & $\begin{array}{c}\mathbf{2 . 4 6} \\
(0.92)\end{array}$ & $\begin{array}{c}0.96 \\
(0.06)\end{array}$ & $\begin{array}{c}\mathbf{1 . 0 0} \\
(0.04)\end{array}$ & $\begin{array}{c}\mathbf{2 . 3 8} \\
(1.03)\end{array}$ \\
\hline \multirow[t]{4}{*}{1992} & $\begin{array}{l}\text { All } \\
\text { (Std Dev) }\end{array}$ & $\begin{array}{c}1.02 \\
(0.13) \\
\end{array}$ & $\begin{array}{c}0.87 \\
(0.23) \\
\end{array}$ & $\begin{array}{c}1.01 \\
(0.11) \\
\end{array}$ & $\begin{array}{c}1.01 \\
(0.03) \\
\end{array}$ & $\begin{array}{r}0.89 \\
(0.33) \\
\end{array}$ \\
\hline & $\begin{array}{l}\text { Big } 4 \\
\text { (Std Dev) }\end{array}$ & $\begin{array}{c}0.96 \\
(0.06) \\
\end{array}$ & $\begin{array}{c}0.84 \\
(0.23) \\
\end{array}$ & $\begin{array}{c}0.97 \\
(0.05) \\
\end{array}$ & $\begin{array}{c}0.99 \\
(0.01) \\
\end{array}$ & $\begin{array}{c}0.81 \\
(0.18) \\
\end{array}$ \\
\hline & $\begin{array}{l}\text { Other Domestic } \\
\text { (Std Dev) }\end{array}$ & $\begin{array}{c}\mathbf{1 . 0 7} \\
(0.15)\end{array}$ & $\begin{array}{c}\mathbf{0 . 9 4} \\
(0.26)\end{array}$ & $\begin{array}{c}\mathbf{1 . 0 5} \\
(0.13)\end{array}$ & $\begin{array}{c}\mathbf{1 . 0 2} \\
(0.03)\end{array}$ & $\begin{array}{c}\mathbf{1 . 0 0} \\
(0.39)\end{array}$ \\
\hline & $\begin{array}{l}\text { Foreign } \\
\text { (Std Dev) }\end{array}$ & $\begin{array}{c}1.01 \\
(0.14) \\
\end{array}$ & $\begin{array}{c}0.83 \\
(0.24) \\
\end{array}$ & $\begin{array}{c}1.00 \\
(0.12)\end{array}$ & $\begin{array}{c}1.01 \\
(0.03)\end{array}$ & $\begin{array}{c}0.84 \\
(0.33)\end{array}$ \\
\hline \multirow[t]{4}{*}{1993} & $\begin{array}{l}\text { All } \\
\text { (Std Dev) }\end{array}$ & $\begin{array}{c}0.96 \\
(0.14)\end{array}$ & $\begin{array}{c}1.03 \\
(0.42)\end{array}$ & $\begin{array}{c}1.02 \\
(0.07)\end{array}$ & $\begin{array}{c}0.94 \\
(0.10)\end{array}$ & $\begin{array}{c}0.99 \\
(0.48)\end{array}$ \\
\hline & $\begin{array}{l}\text { Big } 4 \\
\text { (Std Dev) }\end{array}$ & $\begin{array}{c}0.87 \\
(0.18) \\
\end{array}$ & $\begin{array}{c}0.80 \\
(0.42)\end{array}$ & $\begin{array}{c}0.99 \\
(0.10) \\
\end{array}$ & $\begin{array}{c}0.87 \\
(0.10) \\
\end{array}$ & $\begin{array}{c}0.69 \\
(0.49) \\
\end{array}$ \\
\hline & $\begin{array}{l}\text { Other Domestic } \\
\text { (Std Dev) }\end{array}$ & $\begin{array}{c}\mathbf{1 . 0 0} \\
(0.03)\end{array}$ & $\begin{array}{c}0.90 \\
(0.48)\end{array}$ & $\begin{array}{c}1.01 \\
(0.03)\end{array}$ & $\begin{array}{c}\mathbf{0 . 9 9} \\
(0.02) \\
\end{array}$ & $\begin{array}{c}0.90 \\
(0.50)\end{array}$ \\
\hline & $\begin{array}{l}\text { Foreign } \\
(\text { Std Dev })\end{array}$ & $\begin{array}{c}0.97 \\
(0.16) \\
\end{array}$ & $\begin{array}{r}\mathbf{1 . 2 6} \\
(0.34) \\
\end{array}$ & $\begin{array}{c}\mathbf{1 . 0 4} \\
(0.07) \\
\end{array}$ & $\begin{array}{c}0.94 \\
(0.13) \\
\end{array}$ & $\begin{array}{r}1.22 \\
(0.45) \\
\end{array}$ \\
\hline \multirow[t]{4}{*}{1994} & $\begin{array}{l}\text { All } \\
\text { (Std Dev) }\end{array}$ & $\begin{array}{c}0.99 \\
(0.17)\end{array}$ & $\begin{array}{c}1.00 \\
(0.29)\end{array}$ & $\begin{array}{c}0.98 \\
(0.06)\end{array}$ & $\begin{array}{c}1.01 \\
(0.15)\end{array}$ & $\begin{array}{c}0.98 \\
(0.35)\end{array}$ \\
\hline & $\begin{array}{l}\text { Big } 4 \\
\text { (Std Dev) }\end{array}$ & $\begin{array}{c}\mathbf{1 . 1 5} \\
(0.21) \\
\end{array}$ & $\begin{array}{c}\mathbf{1 . 1 6} \\
(0.15) \\
\end{array}$ & $\begin{array}{c}\mathbf{1 . 0 4} \\
(0.07) \\
\end{array}$ & $\begin{array}{c}\mathbf{1 . 1 1} \\
(0.17)\end{array}$ & $\begin{array}{c}\mathbf{1 . 3 3} \\
(0.36) \\
\end{array}$ \\
\hline & $\begin{array}{l}\text { Other Domestic } \\
\text { (Std Dev) }\end{array}$ & $\begin{array}{c}0.94 \\
(0.10) \\
\end{array}$ & $\begin{array}{c}1.02 \\
(0.25) \\
\end{array}$ & $\begin{array}{c}0.99 \\
(0.03) \\
\end{array}$ & $\begin{array}{c}0.95 \\
(0.09) \\
\end{array}$ & $\begin{array}{c}0.96 \\
(0.28) \\
\end{array}$ \\
\hline & $\begin{array}{l}\text { Foreign } \\
(\text { Std Dev) }\end{array}$ & $\begin{array}{c}0.95 \\
(0.18) \\
\end{array}$ & $\begin{array}{c}0.92 \\
(0.36)\end{array}$ & $\begin{array}{c}0.95 \\
(0.06) \\
\end{array}$ & $\begin{array}{c}1.00 \\
(0.17)\end{array}$ & $\begin{array}{c}0.87 \\
(0.33)\end{array}$ \\
\hline \multirow[t]{3}{*}{1995} & $\begin{array}{l}\text { All } \\
\text { (Std Dev) }\end{array}$ & $\begin{array}{c}0.97 \\
(0.19)\end{array}$ & $\begin{array}{c}1.00 \\
(0.39)\end{array}$ & $\begin{array}{c}1.02 \\
(0.06)\end{array}$ & $\begin{array}{c}0.95 \\
(0.14)\end{array}$ & $\begin{array}{c}0.98 \\
(0.44)\end{array}$ \\
\hline & $\begin{array}{l}\text { Big } 4 \\
\text { (Std Dev) }\end{array}$ & $\begin{array}{c}0.90 \\
(0.12)\end{array}$ & $\begin{array}{c}\mathbf{1 . 1 5} \\
(0.16)\end{array}$ & $\begin{array}{c}1.00 \\
(0.00)\end{array}$ & $\begin{array}{c}0.90 \\
(0.12)\end{array}$ & $\begin{array}{c}\mathbf{1 . 0 3} \\
(0.07)\end{array}$ \\
\hline & Other Domestic & 0.97 & 1.00 & 1.01 & 0.95 & 0.96 \\
\hline
\end{tabular}




\begin{tabular}{|l|l|c|c|c|c|c|}
\hline & (Std Dev) & $(0.10)$ & $(0.67)$ & $(0.02)$ & $(0.10)$ & $(0.75)$ \\
\hline & Foreign & $\mathbf{1 . 0 2}$ & 0.95 & $\mathbf{1 . 0 4}$ & $\mathbf{0 . 9 8}$ & 0.97 \\
& (Std Dev) & $(0.26)$ & $(0.20)$ & $(0.08)$ & $(0.18)$ & $(0.27)$ \\
\hline
\end{tabular}

Model 1b Inputs: (i) employees, (ii) deposits, (iii) equity capital. Outputs: (i) loans, (ii) investments, (iii) off balance sheet items.

Effch: technical efficiency change relative to constant returns to scale technology. Techch: technological change. Pech: pure technical efficiency change relative to variable returns to scale technology. Sech: scale efficiency change. Tfpch: total factor productivity change. Effch $=$ Pech $*$ Sech. Tfpch $=$ Effch $*$ Techch. (There are some small differences due to rounding.)

Table A13

Malmquist Indices by Year. Model 2.

\begin{tabular}{|c|c|c|c|c|c|c|}
\hline & & Effch & TechCh & Pech & Sech & TfpCh \\
\hline \multirow[t]{4}{*}{1990} & $\begin{array}{l}\text { All } \\
\text { (Std Dev) }\end{array}$ & $\begin{array}{c}0.98 \\
(0.10)\end{array}$ & $\begin{array}{c}0.98 \\
(0.11)\end{array}$ & $\begin{array}{c}0.98 \\
(0.06)\end{array}$ & $\begin{array}{c}0.99 \\
(0.06)\end{array}$ & $\begin{array}{c}0.95 \\
(0.17)\end{array}$ \\
\hline & $\begin{array}{l}\text { Big } 4 \\
\text { (Std Dev) }\end{array}$ & $\begin{array}{c}0.96 \\
(0.03)\end{array}$ & $\begin{array}{c}0.95 \\
(0.13)\end{array}$ & $\begin{array}{c}\mathbf{1 . 0 0} \\
(0.01)\end{array}$ & $\begin{array}{c}0.96 \\
(0.03)\end{array}$ & $\begin{array}{c}0.91 \\
(0.15)\end{array}$ \\
\hline & $\begin{array}{l}\text { Other Domestic } \\
\text { (Std Dev) }\end{array}$ & $\begin{array}{c}\mathbf{1 . 0 1} \\
(0.14) \\
\end{array}$ & $\begin{array}{c}0.98 \\
(0.08) \\
\end{array}$ & $\begin{array}{c}0.98 \\
(0.08) \\
\end{array}$ & $\begin{array}{l}\mathbf{1 . 0 3} \\
(0.08) \\
\end{array}$ & $\begin{array}{c}\mathbf{0 . 9 9} \\
(0.18) \\
\end{array}$ \\
\hline & $\begin{array}{l}\text { Foreign } \\
\text { (Std Dev) }\end{array}$ & $\begin{array}{c}0.93 \\
(0.08) \\
\end{array}$ & $\begin{array}{c}\mathbf{1 . 0 1} \\
(0.15)\end{array}$ & $\begin{array}{c}0.96 \\
(0.06)\end{array}$ & $\begin{array}{c}0.97 \\
(0.03)\end{array}$ & $\begin{array}{c}0.93 \\
(0.21)\end{array}$ \\
\hline \multirow[t]{4}{*}{1991} & $\begin{array}{l}\text { All } \\
\text { (Std Dev) }\end{array}$ & $\begin{array}{c}0.95 \\
(0.17)\end{array}$ & $\begin{array}{c}1.12 \\
(0.20)\end{array}$ & $\begin{array}{c}0.94 \\
(0.14)\end{array}$ & $\begin{array}{c}1.01 \\
(0.07)\end{array}$ & $\begin{array}{c}1.06 \\
(0.30)\end{array}$ \\
\hline & $\begin{array}{l}\text { Big } 4 \\
\text { (Std Dev) }\end{array}$ & $\begin{array}{c}0.94 \\
(0.18)\end{array}$ & $\begin{array}{c}\mathbf{1 . 1 5} \\
(0.24)\end{array}$ & $\begin{array}{c}0.90 \\
(0.12)\end{array}$ & $\begin{array}{c}\mathbf{1 . 0 4} \\
(0.09)\end{array}$ & $\begin{array}{c}1.08 \\
(0.36)\end{array}$ \\
\hline & $\begin{array}{l}\text { Other Domestic } \\
\text { (Std Dev) }\end{array}$ & $\begin{array}{c}\mathbf{1 . 0 0} \\
(0.13) \\
\end{array}$ & $\begin{array}{c}1.09 \\
(0.16) \\
\end{array}$ & $\begin{array}{l}\mathbf{1 . 0 0} \\
(0.10) \\
\end{array}$ & $\begin{array}{c}1.00 \\
(0.04) \\
\end{array}$ & $\begin{array}{c}\mathbf{1 . 0 9} \\
(0.33) \\
\end{array}$ \\
\hline & $\begin{array}{l}\text { Foreign } \\
(\text { Std Dev) }\end{array}$ & $\begin{array}{c}0.86 \\
(0.26)\end{array}$ & $\begin{array}{c}1.14 \\
(0.28)\end{array}$ & $\begin{array}{c}0.87 \\
(0.24)\end{array}$ & $\begin{array}{c}0.98 \\
(0.07)\end{array}$ & $\begin{array}{c}0.98 \\
(0.20)\end{array}$ \\
\hline \multirow[t]{4}{*}{1992} & $\begin{array}{l}\text { All } \\
\text { (Std Dev) }\end{array}$ & $\begin{array}{c}1.08 \\
(0.20)\end{array}$ & $\begin{array}{c}1.01 \\
(0.23)\end{array}$ & $\begin{array}{c}1.06 \\
(0.19)\end{array}$ & $\begin{array}{c}1.02 \\
(0.05)\end{array}$ & $\begin{array}{c}1.09 \\
(0.40)\end{array}$ \\
\hline & $\begin{array}{l}\text { Big } 4 \\
\text { (Std Dev) }\end{array}$ & $\begin{array}{l}1.09 \\
(0.12)\end{array}$ & $\begin{array}{c}\mathbf{1 . 1 0} \\
(0.30)\end{array}$ & $\begin{array}{c}1.10 \\
(0.16)\end{array}$ & $\begin{array}{c}1.00 \\
(0.06)\end{array}$ & $\begin{array}{c}1.21 \\
(0.47)\end{array}$ \\
\hline & $\begin{array}{l}\text { Other Domestic } \\
\text { (Std Dev) }\end{array}$ & $\begin{array}{c}1.01 \\
(0.11)\end{array}$ & $\begin{array}{c}0.93 \\
(0.24)\end{array}$ & $\begin{array}{c}1.00 \\
(0.08)\end{array}$ & $\begin{array}{c}1.02 \\
(0.04)\end{array}$ & $\begin{array}{c}0.94 \\
(0.28)\end{array}$ \\
\hline & $\begin{array}{l}\text { Foreign } \\
\text { (Std Dev) }\end{array}$ & $\begin{array}{c}\mathbf{1 . 2 2} \\
(0.38)\end{array}$ & $\begin{array}{c}1.06 \\
(0.06)\end{array}$ & $\begin{array}{c}\mathbf{1 . 1 7} \\
(0.35)\end{array}$ & $\begin{array}{c}\mathbf{1 . 0 4} \\
(0.04)\end{array}$ & $\begin{array}{c}1.29 \\
(0.49)\end{array}$ \\
\hline \multirow[t]{4}{*}{1993} & $\begin{array}{l}\text { All } \\
\text { (Std Dev) }\end{array}$ & $\begin{array}{c}0.84 \\
(0.20)\end{array}$ & $\begin{array}{c}0.64 \\
(0.34)\end{array}$ & $\begin{array}{c}1.00 \\
(0.09)\end{array}$ & $\begin{array}{c}0.84 \\
(0.17)\end{array}$ & $\begin{array}{c}0.54 \\
(0.42)\end{array}$ \\
\hline & $\begin{array}{l}\text { Big } 4 \\
\text { (Std Dev) }\end{array}$ & $\begin{array}{c}0.85 \\
(0.19)\end{array}$ & $\begin{array}{c}\mathbf{0 . 7 1} \\
(0.41)\end{array}$ & $\begin{array}{c}1.01 \\
(0.02)\end{array}$ & $\begin{array}{c}0.84 \\
(0.18)\end{array}$ & $\begin{array}{c}0.60 \\
(0.45)\end{array}$ \\
\hline & $\begin{array}{l}\text { Other Domestic } \\
\text { (Std Dev) }\end{array}$ & $\begin{array}{c}\mathbf{0 . 8 7} \\
(0.25)\end{array}$ & $\begin{array}{c}\mathbf{0 . 7 1} \\
(0.33)\end{array}$ & $\begin{array}{c}0.97 \\
(0.12)\end{array}$ & $\begin{array}{c}\mathbf{0 . 8 9} \\
(0.16)\end{array}$ & $\begin{array}{c}\mathbf{0 . 6 1} \\
(0.49)\end{array}$ \\
\hline & $\begin{array}{l}\text { Foreign } \\
\text { (Std Dev) }\end{array}$ & $\begin{array}{c}0.78 \\
(0.19) \\
\end{array}$ & $\begin{array}{c}0.45 \\
(0.19) \\
\end{array}$ & \begin{tabular}{|l|}
$\mathbf{1 . 0 3}$ \\
$(0.07)$ \\
\end{tabular} & $\begin{array}{c}0.76 \\
(0.22) \\
\end{array}$ & $\begin{array}{c}0.35 \\
(0.05) \\
\end{array}$ \\
\hline \multirow[t]{4}{*}{1994} & $\begin{array}{l}\text { All } \\
\text { (Std Dev) }\end{array}$ & $\begin{array}{c}1.05 \\
(0.38)\end{array}$ & $\begin{array}{c}1.61 \\
(0.38)\end{array}$ & $\begin{array}{c}0.98 \\
(0.12)\end{array}$ & $\begin{array}{c}1.07 \\
(0.36)\end{array}$ & $\begin{array}{c}1.68 \\
(0.95)\end{array}$ \\
\hline & $\begin{array}{l}\text { Big } 4 \\
\text { (Std Dev) }\end{array}$ & $\begin{array}{c}1.09 \\
(0.50)\end{array}$ & $\begin{array}{c}1.45 \\
(0.25)\end{array}$ & $\begin{array}{c}0.94 \\
(0.11)\end{array}$ & $\begin{array}{c}1.17 \\
(0.45)\end{array}$ & $\begin{array}{c}1.59 \\
(1.05)\end{array}$ \\
\hline & $\begin{array}{l}\text { Other Domestic } \\
\text { (Std Dev) }\end{array}$ & $\begin{array}{c}0.96 \\
(0.15)\end{array}$ & $\begin{array}{c}1.56 \\
(0.43)\end{array}$ & $\begin{array}{c}0.98 \\
(0.16)\end{array}$ & $\begin{array}{c}0.98 \\
(0.05)\end{array}$ & $\begin{array}{c}1.50 \\
(0.52)\end{array}$ \\
\hline & $\begin{array}{l}\text { Foreign } \\
\text { (Std Dev) }\end{array}$ & $\begin{array}{c}\mathbf{1 . 1 8} \\
(0.59)\end{array}$ & $\begin{array}{c}1.95 \\
(0.28)\end{array}$ & $\begin{array}{c}\mathbf{1 . 0 1} \\
(0.02)\end{array}$ & $\begin{array}{c}1.16 \\
(0.60)\end{array}$ & $\begin{array}{c}\mathbf{2 . 2 9} \\
(1.45)\end{array}$ \\
\hline \multirow[t]{4}{*}{1995} & $\begin{array}{l}\text { All } \\
\text { (Std Dev) }\end{array}$ & $\begin{array}{c}1.08 \\
(0.24)\end{array}$ & $\begin{array}{c}0.80 \\
(0.12)\end{array}$ & $\begin{array}{c}0.99 \\
(0.09)\end{array}$ & $\begin{array}{c}1.08 \\
(0.23)\end{array}$ & $\begin{array}{c}0.86 \\
(0.23)\end{array}$ \\
\hline & $\begin{array}{l}\text { Big } 4 \\
\text { (Std Dev) }\end{array}$ & $\begin{array}{c}1.02 \\
(0.20) \\
\end{array}$ & \begin{tabular}{|c|}
$\mathbf{0 . 8 8}$ \\
$(0.12)$ \\
\end{tabular} & $\begin{array}{l}\mathbf{1 . 0 5} \\
(0.10) \\
\end{array}$ & $\begin{array}{c}0.97 \\
(0.16) \\
\end{array}$ & $\begin{array}{c}\mathbf{0 . 9 0} \\
(0.27) \\
\end{array}$ \\
\hline & $\begin{array}{l}\text { Other Domestic } \\
\text { (Std Dev) }\end{array}$ & $\begin{array}{c}\mathbf{1 . 1 3} \\
(0.30)\end{array}$ & $\begin{array}{c}0.79 \\
(0.11)\end{array}$ & $\begin{array}{c}0.99 \\
(0.08)\end{array}$ & $\begin{array}{c}1.14 \\
(0.27)\end{array}$ & $\begin{array}{c}0.89 \\
(0.22)\end{array}$ \\
\hline & $\begin{array}{l}\text { Foreign } \\
(\text { Std Dev) }\end{array}$ & $\begin{array}{c}1.05 \\
(0.16)\end{array}$ & $\begin{array}{c}0.71 \\
(0.09)\end{array}$ & $\begin{array}{c}0.93 \\
(0.06)\end{array}$ & $\begin{array}{c}1.13 \\
(0.21)\end{array}$ & $\begin{array}{c}0.74 \\
(0.20)\end{array}$ \\
\hline
\end{tabular}

Model 2: Inputs: (i) interest expenses, (ii) non-interest expenses. Outputs: (i) net interest income, (ii) non-interest income. Effch: technical efficiency change relative to constant returns to scale technology. Techch: technological change. Pech: pure technical efficiency change relative to variable returns to scale technology. Sech: scale efficiency change. Tfpch: total factor productivity change. Effch $=$ Pech $*$ Sech. Tfpch $=$ Effch $*$ Techch. (There are some small differences due to rounding.) 


\section{CESifo Working Paper Series}

(for full list see www.cesifo.de)

749 Hans Gersbach, Democratic Mechanisms: Double Majority Rules and Flexible Agenda Costs, July 2002

750 Bruno S. Frey and Stephan Meier, Pro-Social Behavior, Reciprocity or Both?, July 2002

751 Jonas Agell and Helge Bennmarker, Wage Policy and Endogenous Wage Rigidity: A Representative View From the Inside, July 2002

752 Edward Castronova, On Virtual Economies, July 2002

753 Rebecca M. Blank, U.S. Welfare Reform: What's Relevant for Europe?, July 2002

754 Ruslan Lukach and Joseph Plasmans, Measuring Knowledge Spillovers Using Patent Citations: Evidence from the Belgian Firm's Data, July 2002

755 Aaron Tornell and Frank Westermann, Boom-Bust Cycles in Middle Income Countries: Facts and Explanation, July 2002

756 Jan K. Brueckner, Internalization of Airport Congestion: A Network Analysis, July 2002

757 Lawrence M. Kahn, The Impact of Wage-Setting Institutions on the Incidence of Public Employment in the OECD: 1960-98, July 2002

758 Sijbren Cnossen, Tax Policy in the European Union, August 2002

759 Chandima Mendis, External Shocks and Banking Crises in Developing Countries: Does the Exchange Rate Regime Matter?, August 2002

760 Bruno S. Frey and Lars P. Feld, Deterrence and Morale in Taxation: An Empirical Analysis, August 2002

761 Lars Calmfors and Åsa Johansson, Nominal Wage Flexibility, Wage Indexation and Monetary Union, August 2002

762 Alexander R. W. Robson and Stergios Skaperdas, Costly Enforcement of Property Rights and the Coase Theorem, August 2002

763 Horst Raff, Preferential Trade Agreements and Tax Competition for Foreign Direct Investment, August 2002

764 Alex Cukierman and V. Anton Muscatelli, Do Central Banks have Precautionary Demands for Expansions and for Price Stability? - Theory and Evidence, August 2002

765 Giovanni Peri, Knowledge Flows and Knowledge Externalities, August 2002

766 Daniel Friedman and Nirvikar Singh, Equilibrium Vengeance, August 2002 
767 Sam Bucovetsky and Michael Smart, The Efficiency Consequences of Local Revenue Equalization: Tax Competition and Tax Distortions, August 2002

768 Tapio Palokangas, International Labour Market Regulation and Economic Growth with Creative Destruction, August 2002

769 Rudi Dornbusch, The New International Architecture, September 2002

770 Hans-Werner Sinn, Weber's Law and the Biological Evolution of Risk Preferences: The Selective Dominance of the Logarithmic Utility Function, September 2002

771 Thomas Mayer, The Macroeconomic Loss Function: A Critical Note, September 2002

772 Seppo Honkapohja and Kaushik Mitra, Learning Stability in Economies with Heterogenous Agents, September 2002

773 David Laidler, Inflation Targets Versus International Monetary Integration - A Canadian Perspective, September 2002

774 Morten I. Lau, Panu Poutvaara, and Andreas Wagener, The Dynamic Cost of the Draft, September 2002

775 Steven Brakman, Harry Garretsen, and Charles van Marrewijk, Locational Competition and Agglomeration: The Role of Government Spending, September 2002

776 Anke S. Kessler and Christoph Lülfesmann, The Theory of Human Capital Revisited: On the Interaction of General and Specific Investments, September 2002

777 Kjell Erik Lommerud, Frode Meland and Lars Sørgard, Unionized Oligopoly, Trade Liberalization and Location Choice, September 2002

778 Antonio Merlo and François Ortalo-Magné, Bargaining over Residential Real Estate: Evidence from England, September 2002

$779 \mathrm{Yu}-\mathrm{Fu}$ Chen and Michael Funke, Exchange Rate Uncertainty and Labour Market Adjustment under Fixed and Flexible Exchange Rates, September 2002

780 Michael S. Michael, International Migration, Income Taxes and Transfers: A Welfare Analysis, September 2002

781 Clemens Fuest and Alfons Weichenrieder, Tax Competition and Profit Shifting: On the Relationship between Personal and Corporate Tax Rates, October 2002

782 Jan Bouckaert and Hans Degryse, Softening Competition by Enhancing Entry: An Example from the Banking Industry, October 2002

783 Johann K. Brunner and Susanne Pech, Adverse Selection in the Annuity Market with Sequential and Simultaneous Insurance Demand, October 2002 
784 Gregory D. Hess and Eduard Pelz, The Economic Welfare Cost of Conflict: An Empirical Assessment, October 2002

785 Jan Erik Askildsen, Uwe Jirjahn, and Stephen C. Smith, Works Councils and Environmental Investment: Theory and Evidence from German Panel Data, October 2002

786 Geir H. Bjønnes, Dagfinn Rime, and Haakon O. Aa. Solheim, Volume and Volatility in the FX-Market: Does it matter who you are?, October 2002

787 John Evans and John Fingleton, Entry Regulation and the Influence of an Incumbent Special Interest Group, October 2002

788 Wolfgang Ochel, International Comparisons and Transfer of Labour Market Institutions, October 2002

789 B. Gabriela Mundaca, Moral Hazard Effects of Bailing out under Asymmetric Information, October 2002

790 Gene M. Grossman and Edwin L.-C. Lai, International Protection of Intellectual Property, October 2002

791 John Hassler, José V. Rodriguez Mora, Kjetil Storesletten, and Fabrizio Zilibotti, A Positive Theory of Geographic Mobility and Social Insurance, October 2002

792 Paul De Grauwe and Marianna Grimaldi, The Exchange Rate in a Model with Heterogeneous Agents and Transactions Costs, October 2002

793 Guido Friebel and Mariassunta Giannetti, Fighting for Talent: Risk-shifting, Corporate Volatility, and Organizational Change, October 2002

794 Jan Erik Askildsen, Badi H. Baltagi, and Tor Helge Holmås, Will Increased Wages Reduce Shortage of Nurses? A Panel Data Analysis of Nurses' Labour Supply, October 2002

795 Marko Köthenbürger and Panu Poutvaara, Social Security Reform and Intergenerational Trade: Is there Scope for a Pareto-Improvement?, October 2002

796 Paul De Grauwe and Laura Rinaldi, A Model of the Card Payment System and the Interchange Fee, October 2002

797 Volker Böhm and Tomoo Kikuchi, Dynamics of Endogenous Business Cycles and Exchange Rate Volatility, October 2002

798 Mariam Camarero, Javier Ordóñez, and Cecilio Tamarit, The Euro-Dollar Exchange Rate: Is it Fundamental?, October 2002

799 Misa Tanaka, How Do Bank Capital and Capital Adequacy Regulation Affect the Monetary Transmission Mechanism?, October 2002 
800 Jörg Baten and Andrea Wagner, Autarchy, Market Disintegration, and Health: The Mortality and Nutritional Crisis in Nazi Germany, 1933-1937, October 2002

801 Saku Aura, Uncommitted Couples: Some Efficiency and Policy Implications of Marital Bargaining, October 2002

802 Wolfram F. Richter, Delaying Integration of Immigrant Labor for the Purpose of Taxation, October 2002

803 Gil S. Epstein and Shmuel Nitzan, The Politics of Randomness, October 2002

804 John Hassler and José V. Rodriguez Mora, Should UI Benefits Really Fall over Time?, October 2002

805 Friedrich Breyer and Stefan Felder, The Dead-anyway Effect Revis(it)ed, October 2002

806 Assar Lindbeck and Solveig Wikström, E-exchange and the Boundary between Households and Organizations, November 2002

807 Dieter Bös, Contests Among Bureaucrats, November 2002

808 Steven Brakman, Harry Garretsen, and Marc Schramm, The Strategic Bombing of German Cities during World War II and its Impact on City Growth, November 2002

809 Florian Englmaier and Achim Wambach, Contracts and Inequity Aversion, November 2002

810 Sarbajit Sengupta, Delegating Recruitment under Asymmetric Information, December 2002

811 Rajshri Jayaraman, On the Partial Public Provision of a Private Good, December 2002

812 Stéphanie Stolz, Banking Supervision in Integrated Financial Markets: Implications for the EU, December 2002

813 Christian Keuschnigg, Taxation of a Venture Capitalist with a Portfolio of Firms, December 2002

814 Inés Macho-Stadler and David Pérez-Castrillo, Settlement in Tax Evasion Prosecution, December 2002

815 Rainer Niemann and Dirk Simons, Costs, Benefits, and Tax-induced Distortions of Stock Option Plans, December 2002

816 Jan-Egbert Sturm and Barry Williams, Deregulation, Entry of Foreign Banks and Bank Efficiency in Australia, December 2002 